National

\title{
NAS-NS
}

3041

Academy

of

Sciences

National Research Council

NUCLEAR SCIENCE SERIES

\section{The Radiochemistry of Cobalt}




\section{COMMITTEE ON CHEMICAL SCIENCES}

James L. Kinsey, Cochairman, Massachusetts Institute of Technology

Alan Schriesheim, Cochairman, Exxon Research and Engineering Company

William Spindel, Executive Secretary, National Academy of Sciences

Andreas Acrivos, Stanford University

Allen J. Bard, University of Texas, Austin

Fred Basolo, Northwestern University

Stephen J. Benkovic. Pennsylvania State University

R. Stephen Berry. University of Chicago

Alfred E. Brown, Washington. D. C.

David A. Evans, California Institute of Technology

Roald Hoffmann, Cornell University

Robert E. Naylor, Rohm and Hass Co.

George C. Pimentel, University of California

Norman Sutin, Brookhaven National Laboratory

Berry M. Trost, University of Wisconsin

Edel Wasserman, E. I. du Pont de Nemours \& Co., Inc.

Liaison Members

Richard S. Nicholson, National Science Foundation

Elliot S. Pierce, U. S. Department of Energy

\section{SUBCOMMITTEE ON NUCLEAR AND RADIOCHEMISTRY}

Darleane C. Hoffman, Chairman, Los Alamos National Laboratory

Eugene T. Chulick, Babcock \& Wilcox Co.

Christopher Gatrousis, Lawrence Livermore National Laboratory

Peter E. Haustein, Brookhaven National Laboratory

Rolfe H. Herber, Wright-Rieman Laboratories

Paul J. Karol, Carnegie-Mellon University

Edward S. Macias, Washington University

Michael J. Welch, Washington University School of Medicine

Raymond G. Wymer. Oak Ridge National Laboratory

$$
\text { Liaison Member }
$$

John L. Burnett, U. S. Department of Energy 


\section{DISCLAIMER}

This report was prepared as an account of work sponsored by an agency of the United States Government. Neither the United States Government nor any agency Thereof, nor any of their employees, makes any warranty, express or implied, or assumes any legal liability or responsibility for the accuracy, completeness, or usefulness of any information, apparatus, product, or process disclosed, or represents that its use would not infringe privately owned rights. Reference herein to any specific commercial product, process, or service by trade name, trademark, manufacturer, or otherwise does not necessarily constitute or imply its endorsement, recommendation, or favoring by the United States Government or any agency thereof. The views and opinions of authors expressed herein do not necessarily state or reflect those of the United States Government or any agency thereof. 


\section{DISCLAIMER}

Portions of this document may be illegible in electronic image products. Images are produced from the best available original document. 


\section{The Radiochemistry of Cobalt}

L. C. BATE and G. W. LEDDICOTTE

Oak Ridge National Laboratory

Oak Ridge, Tennessee

Reprinted by the Technical Information Center

U. S. Depertment of Energy

\footnotetext{
Subcommittee on Radiochemistry

National Academy of Sciences-National Research Council
} 
Available as NAS-NS-3041 for $\$ 10.25$ from

National Technical Information Service

U. S. Depertment of Commerce

Springfield, Virginia 22161

Pnnted in the United States of Amenca

USDOE Technical Information Center, Oak Ridge, Tennessee

1961, latest printing October 1982 


\section{FOREWORD}

The Subcommittee on Radiochemistry is one of a number of subcommittees working under the Committee on Nuclear Sclence within the National Academy of Sclences - National Research Council. Its members represent government, industrial, and university laboratories in the areas of nuclear chemistry and analytical chemistry.

The subcommittee has concerned itself with those areas of nuclear science which involve the chemist, such as the collection and distribution of radiochemical procedures, the establishment of speciflcations for radlochemically pure reagents, avallability of cyclotron time for service irradiations, the place of radiochemistry in the undergraduate college program, etc.

This series of monographs has grown out of the need for up-to-date compllations of radiochemical information and procedures. The Subcommittee has endeavored to present a serles which will be of maximum use to the working scientist and which contains the latest ava1lable information. Each monograph collects in one volume the pertinent information required for radiochemical work with an individual element or a group of closely related elements.

An expert in the radiochemistry of the particular element has written the monograph, following a standard format developed by the Subcommittee. The Atomic Energy Commission has sponsored the printing of the series.

The Subcommittee is confident these publications will be useful not only to the radiochemist but also to the research worker in other flelds such as physics, blochemistry or medicine who wlshes to use radiochemical techniques to solve a specific problem.

W. Wayne Meinke, Chaiman Subcommittee on Radiochemistry 


\section{INTRODUCTION}

This volume which deals with the radiochemistry of cobalt is one of a series of monographs on radiochemistry of the elements. There is included a review of the nuclear and chemical features of particular interest to the radiochemist, a discussion of problems of dissolution of a sample and counting techniques, and finaliy, a collection of radiochemical procedures for the element as found in the literature.

The series of monographs will cover all elements for which radiochemical procedures are pertinent. Plans include revision of the monograph periodically as new techniques and procedures warrant. The reader is therefore encouraged to call to the attention of the author any published or unpublished material on the radiochemistry of cobalt which might be included in a revised version of the monograph. 


\section{CONTENTS}

I. General Reviews of the Inorganic and Analytical

Chemistry of Cobalt . . . . . . . . . . . . . 1

II. The Radioactive Nuclides of Cobalt . . . . . . . . . 2

III. The Chemistry of Cobalt and Its Application to the Radiochemistry of the Cobalt Radionuclides . . . . . 4

A. The General Chemistry of Cobalt . . . . . . . . 5

1. Metallic Cobalt ............. 6

2. The Simple Cobalt Compounds . . . . . . . . 7

3. The Complex Compounds of Cobalt . . . . . . 7

4. The Organometallic Compounds of Cobalt . . . . Il

B. The Analytical Chemistry of Cobalt . . . . . . . . 11

1. Separations by Precipitation.......... 14

2. Separations by Electrodeposition........ 18

3. Separations by Solvent Extraction . . . . . . 19

a. Ion Association System . . . . . . . 20

b. Chelate Compound Systems . . . . . . . 22

4. Separations by Chromatography . . . . . . . . 25

a. With Inorganic Absorbents . . . . . . 25

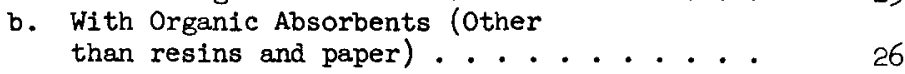

c. With Ion Exchange Resins . . . . . . . . 27

d. With Chelating Ion Exchange Resins . . . . 29

e. With Paper and Similar Materials . . . . 29

IV. Dissolution of Samples Containing Radioactive Cobalt . . 32

V. Safety Practices . . . . . . . . . . . . . 32

VI. Counting Techniques for the Radioactive Cobalt
Isotopes . . . . . . . . . . . . . . . 33

VII. Collection of Detalled Radiochemical Procedures for the Cobalt Radionuclides . . . . . . . . . . 35

References ....................... 79 


\title{
The Radiochemistry of Cobalt
}

\author{
L. C. BATE and G. W. LEDDICOTTE \\ Oak Ridge National Laboratory* \\ Oak Ridge, Tennessee
}

I. GENERAL REVIEWS OF THE INORGANIC AND ANALYTICAL CHEMISTRY OF COBALT

1. W. J. Williams, "Analytical Chemistry of Cobalt," Talanta 1 , 88-104 (1958).

2. B. S. Evans, "The Determination of Cobalt. A New Method or Volumetric Determination and a New Method for Its Determination in Steel," Analyst 62, 363 (1937).

3. W. E. Harris and T. R. Sweet, "Determination of Cobalt in CobaltNickel Solutions," Anal. Chem. 26, 1648 (1954).

4. H. H. Willard and D. Hall, "The Separation and Determination of Cobalt," J. Am. Soc. 114, 2219-31, 2237-53 (1922).

5. G. Cilarlot and D. Bezier, Quantitative Inorganic Analysis (Translated by R. C. Murray), p. 406-412, J. Willey and Sons, N. Y. (1957).

6. Centre D'Information Du Cobalt, Cobalt Monograph, Brussels, Belgium (1960).

7. Mellor, J. W., A Comprehensive Treatise on Inorganic and Theoretical Chemistry, Vol. XIV, pp. 419-859, Longman, Green and Co. Ltd., London, 1935.

8. Gmelins Handbuch der Anorganischen Chemie, System No. 58, Kobalt, 8th Ed., Part A. Verlag Chemie G.m.b.H., Berlin, 1932.

9. Sidgwick, N. V., The Chemical Elements and Their Compounds, Vol. II, pp. 1375-1425, 0xford Press, London (1950).

10. Hillebrand, W. F., Lundell, G. E. F., Bright, H. A., and Hoffman, J. I., Applied Inorganic Analysis, and Ed., pp. 417-424, J. Wiley and Sons, New York (1953).

11. Scott's Standard Methods of Chemical Analysis, Vol. 1, N. H. Furman, ed., Fifth edition (Van Nostrand, New York, 1939) pp. 305-330.

\footnotetext{
* Operated by Union Carbide Nuclear Company for the U. S. Atomic Energy
} Commission. 
12. Remy, H., Treatise on Analytical Chemistry, Vol. II, p. 290-306, Elsevier, Amsterdam, 1956.

13. Kleinberg, J., Argersinger, W. J., Jr., and Griswold, E., Inorganic Chemistry, Heath, Boston, 1960.

II. THE RADIOACTIVE NUCLIDES OF COBALT

The radioactive nuclides of cobalt which are of interest to the radiochemist are given in Table $I$. This table has been compiled from information appearing in reports by Strominger, et al., (1) and by Hughes and Schwartz. (2)

Table I. The Radoactive Nuclides of Cobalt

\begin{tabular}{|c|c|c|c|c|}
\hline $\begin{array}{l}\text { Radio- } \\
\text { nuclide }\end{array}$ & Half-Life & $\begin{array}{l}\text { Mode of } \\
\text { Decay }\end{array}$ & $\begin{array}{c}\text { Energy of Rediation, } \\
\text { Mev }\end{array}$ & Produced By \\
\hline $\mathrm{Co}^{54}$ & $0.18 \mathrm{sec}$ & $\beta^{+}$ & $>7.4$ & $\mathrm{Fe}-\mathrm{p}-\mathrm{n}$ \\
\hline $\mathrm{Co}^{55}$ & $18.2 \mathrm{hrs}$ & $\mathrm{B}^{+}, \mathrm{EC}$ & $\beta^{+}: 1.5$ & $\mathrm{Fe}-\mathrm{d}-\mathrm{n}, \mathrm{Ni}-\gamma-\mathrm{p} 2 \mathrm{n}$ \\
\hline & & & $\gamma: 0.477,0.935,1.41$ & $\mathrm{Fe}-\mathrm{p}-\gamma$ \\
\hline $\mathrm{Co}^{56}$ & 72 day & $E C, \beta^{+}$ & $\begin{aligned} \gamma: & 0.845,1.26,1.74 \\
& 2.01,2.55,3.25\end{aligned}$ & 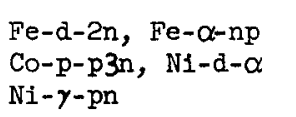 \\
\hline $\mathrm{Co}^{57}$ & 270 day & $\beta^{+}$ & $\beta^{+}: 0.26$ & $F e-d-n, F e-p-\gamma$ \\
\hline & & & $\gamma: 0.119,0.131$ & \\
\hline$c o^{58 m}$ & $9.2 \mathrm{hrs}$ & IT & $\gamma: 0.025$ & $\begin{array}{l}M n-\alpha-n, \text { Co-d-p2n } \\
\text { Co-n-2n, Ni-n-p } \\
N 1-\alpha-2 p, \text { Fe } 58-p-n \\
\text { Co- } \gamma-n\end{array}$ \\
\hline $\mathrm{Co}^{58}$ & 72 day & $E C, B^{+}$ & $\beta^{+}: 0.47$ & $M n-\alpha-n, F e-d-n$ \\
\hline & & & $\gamma: \begin{array}{l}0.81 \\
1.62 \\
0.51\left(\text { w1th B }{ }^{+}\right)\end{array}$ & $\begin{array}{l}F e^{58}-p-n, F e-p-n, \\
F e-\alpha-n p, \quad F e-p-\gamma \\
\text { Cu-p-pn, Ni-n-p }\end{array}$ \\
\hline \multirow[t]{2}{*}{$\mathrm{Co}^{60 \mathrm{~m}}$} & $10.1 \mathrm{~min}$ & $I T, B^{-}$ & $B^{-}: 1.56$ & Co-n- $\gamma$, Co- $\alpha-p$ \\
\hline & & & $\gamma: 0.059$ & $N i-n-p$ \\
\hline \multirow[t]{2}{*}{$\mathrm{Co}^{60}$} & $5.3 \mathrm{y}$ & $\beta^{-}$ & $\beta^{-}: 0.306$ & Co-d-p, Co-n-y \\
\hline & & & $\gamma: 1.33,1.17$ & $\mathrm{~N} 1-\alpha-\alpha, \quad \mathrm{Cu}-\mathrm{n}-\alpha$ \\
\hline $\mathrm{Co}^{61}$ & $99 \min$ & $B^{-}$ & $\beta^{-}: 1.42,1.00$ & $\begin{array}{l}\text { Co- } \alpha-2 p, \quad C q-t-p \\
N 1-\gamma-p, \quad N 14_{-p-\alpha} \\
N i 61-n-p, \quad N i-d-\alpha n \\
C u-\gamma-2 p, \quad C u-\gamma-\alpha\end{array}$ \\
\hline $\mathrm{Co}^{62}$ & $13.9 \mathrm{~min}$ & $B^{-}$ & $\beta-\gamma: 1.3$ & $N 1^{62}-n-p$ \\
\hline $\mathrm{Co}^{62}$ & $1.6 \mathrm{~min}$ & $B^{-}$ & $\gamma$ & $\mathrm{Ni}^{62}-\mathrm{n}-\mathrm{p}, \mathrm{Ni}^{64_{-}-\mathrm{d}-\alpha}$ \\
\hline $\mathrm{Co}^{64}$ & $\sim 5 \min$ & & & $\mathrm{N} i^{64}-\mathrm{n}-\mathrm{p}$ \\
\hline
\end{tabular}


The decay schemes ${ }^{(1)}$ for the principal radionuclides of cobalt are shown in Figure 1.

Figure 1. Decay Schemes of the Cobalt Radionuclides
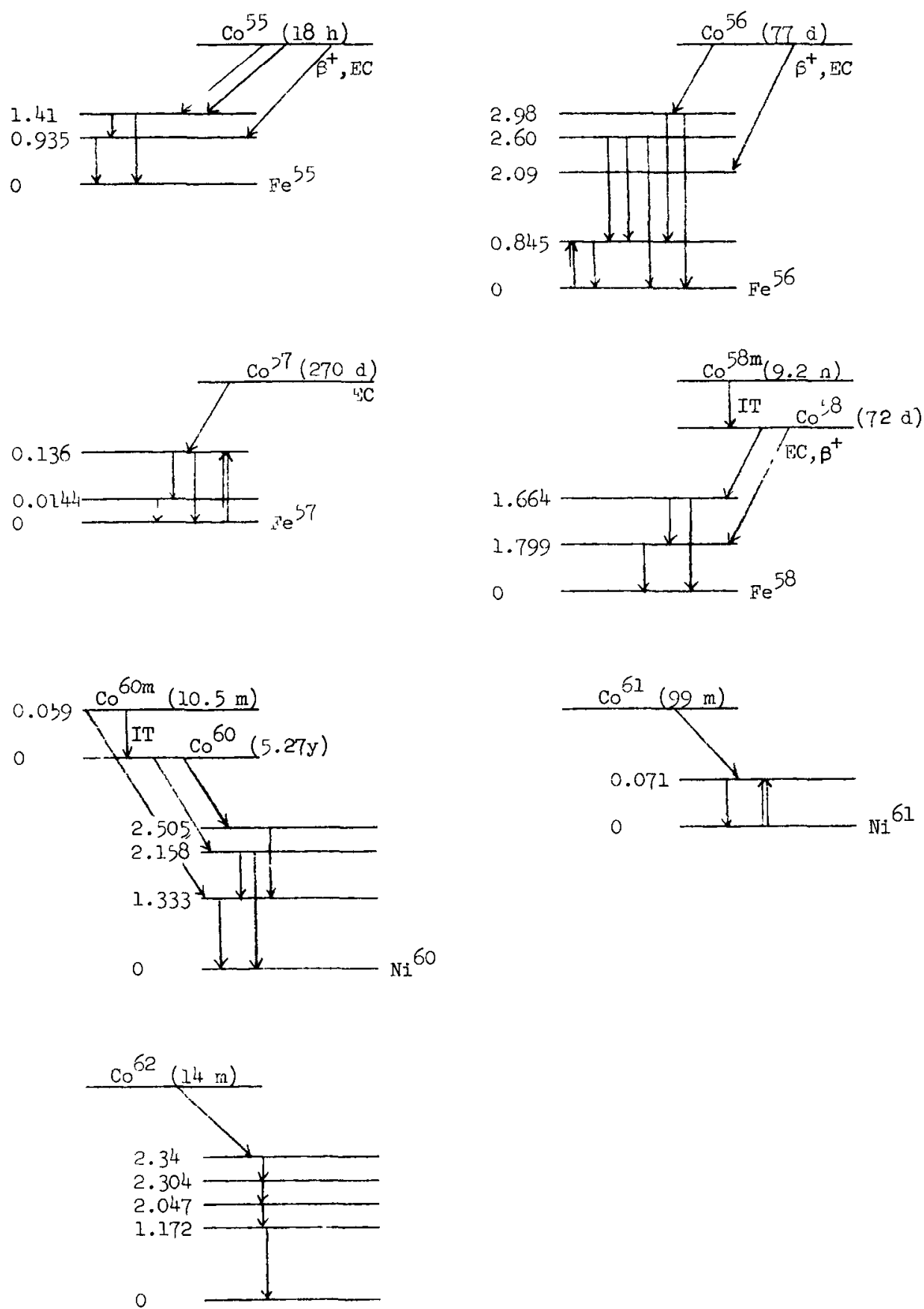
III. THE CHEMISTRY OF COBALT AND ITS APPLICATION TO THE RADIOCHEMISTRY OF THE COBALT RADIONUCLIDES

Radiochemistry is probably best described as being an analysis technique used primarily either (1) to assist in obtaining a pure radionuclide in some form so that an absolute measurement of its radioactivity, radiation energies, and half-life can be made, or (2) to determine the amount of radioactivity of a particular radioelement in a radionuclide mixture, or (3) to complete a radioactivation analysis being used to determine the concentratiol of a specific stable element in a particular sample material. In order to be an aid in accomplishing any one of the above interests, radiochemistry usually considers the isolation of the desired radionuclide by either carrier or carrier-free separation methods.

Generally, carrier methods are used most frequently in radiochemistry. They involve the addition of a small amount of inactive stable element to a solution of the Irradiated material to serve as a carrier of the radionuclide of that element through the separation method. In carrier-free separations, 1.e., those radiochemical techniques used mostly for absolute radioactivity measurements, it is required that the radioelement be isolated in a manner capable of giving either no amount or a minimal amount of stable element in the final form to be used in the radioactivity measurements.

In most instances, analytical radiochemistry is dependent upon more conventional Ideas in analytical chemistry involving separations by such methods as precipitation, solvent extraction, chromatography, volatilization, and/or electroanalysis and the subsequent presentation of the isolated radioelement in a form suitable for a measurement o.? the radioelement's radioactivity. One major difference exists between carrier radiochemistry and more conventional techniques in that it is not always necessary to recover completely the added amount of carrier element, since a radiochemical analysis 1s.designed to assure that the atoms of a radioactive element achieve an 1sotopic state with the atoms of the inactive element, and any loss of the radioactive species is proportional to the "loss" of carrier during the separation process. 
Colorimetric, polarographic and similar analysis techniques are seldom used in radiochemistry, because they do not separate the desired radionuclide from contaminants (either radioactive or stable) in the mixture being analyzed. However, some of the developments used in these analysis techniques may be useful in radiochemistry.

Thus, the information that follows generally describes the behavior of cobalt and its compounds and how this behavior can be used in devising radiochemical analyses for the cobalt radionuclides. More detalled information can be obtained either from the references given in this section or from the references given in Section I of this monograph.

\section{A. The General Chemistry of Cobalt}

The chemical properties of cobalt are intermediate to those of iron and nickel. It forms compounds that chiefly exhibit a valence of +2 or +3. It also shows a valence of +1 in a few complex nitrosyls and carbonyls and a valence of +4 in some fluoride complexes.

In the simple cobalt compounds, the divalent forms are more stable. Cobaltous ion, $\mathrm{Co}^{+2}$, is basic and is not easily hydrolyzed in an aqueous solution. A few simple cobiltic, $\mathrm{Co}^{+3}$, sults, such as $\mathrm{Co}_{2}\left(\mathrm{SO}_{4}\right)_{4} \cdot 18 \mathrm{H}_{2} \mathrm{O}$ and $\mathrm{CoF}_{3}$, are known. Most simple $\mathrm{Co}^{+3}$ compounds are unstable because $\mathrm{Co}^{+3}$ is a strone oxidizing agent and it cannot exist in aqueous media. The trivilent state of cobalt forms many complex ions, most of which are stable in aqueous media. In particular, such coordination complexes of $\mathrm{Co}^{+3}$ as the cobiltinitrates, the cobalticyanides, and the cobaltimmines are most stable. On the other hand, cobaltous ions, $\mathrm{Co}^{+2}$, in the complexed state are very unstable and can be readily oxidized to the Co +3 rorm by ordinary oxidants.

In its electrochemical properties, (3) cobalt is more active than nickel and is more noble than cadmium. Although this relutionship exists in mun irreversible systems, the relative degree of activity or nobility will vary. Lutimer ${ }^{(l)}$ reports that the reversible potentials for certain $0 i$ 
the cobaltous-cobalt and cobaltic-cobal.tous couples are as follows:

$$
\begin{aligned}
& \mathrm{Co}^{++}+2 \mathrm{e}^{-}=\mathrm{Co} \quad \mathrm{E}^{\circ}=-0.277 \mathrm{v} \\
& \mathrm{Co}(\mathrm{OH})_{2}=2 \mathrm{e}^{-}=\mathrm{Co}+2 \mathrm{OH} \quad \mathrm{E}^{\circ}=-0.73 \mathrm{v} \\
& \mathrm{Co}\left(\mathrm{NH}_{3}\right)_{6}+2 \mathrm{e}^{-}=\mathrm{Co}+6 \mathrm{NH}_{3} \text { (aq.) } \quad \mathrm{E}^{\circ}=+0.42 \mathrm{v} \\
& \mathrm{CoCO}_{3}+2 \mathrm{e}^{-}=\mathrm{Co} \mathrm{CO}_{3}^{-} \quad \mathrm{E}^{\circ}=-0.64 \mathrm{v} \\
& \mathrm{Co}^{+++}+\mathrm{e}^{-}=\mathrm{Co}^{++} \quad \mathrm{E}^{\circ}=+1.842 \mathrm{v} \\
& \mathrm{Co}(\mathrm{OH})_{3}+\mathrm{e}^{-}=\mathrm{Co}(\mathrm{OH})_{2}+\mathrm{OH}^{-} \quad \mathrm{E}^{\circ}=+0.17 \mathrm{v} \\
& \mathrm{Co}\left(\mathrm{NH}_{3}\right)_{6}^{+++}+\mathrm{e}^{-}=\mathrm{Co}\left(\mathrm{NH}_{3}\right)_{6}^{++} \quad \mathrm{I}^{\circ}=+0.10 \mathrm{v} \\
& \mathrm{Co}(\mathrm{CN})_{6}^{-\cdots}+e^{-}=\mathrm{Co}(\mathrm{CN})_{6}^{-4} \quad \mathrm{E}^{\circ}=-0.83 \mathrm{v}
\end{aligned}
$$

The irreversible potentials of cobalt in vartous solutions have recently been measured by Akimov and CJark. (5) The cathodic deposition potentials of cobalt from various $\mathrm{H}_{2} \mathrm{SO}_{4}$ acid concentrations have been measured by Glasstone ${ }^{(6)}$ and in $\mathrm{H}_{2} \mathrm{SO}_{4}$ and in $\mathrm{NaOH}$ by Newberry. (7) Verdieck, et al., ${ }^{(8)}$ have determined the deposition potentials of cobalt from chloride and bromide solutions. Schwabe ${ }^{(9)}$ and El Wakkad and Hickling ${ }^{(10)}$ report on the anodic behavior of cobalt.

\section{Metallic Cobalt}

Cobalt is more frequently obtained as a crude metal from the smelting of such ores as smaltite, $\mathrm{CoAs}_{2}$, linnaeite, $\mathrm{CO}_{3} \mathrm{~S}_{4}$, and cobaltite, CoAss, which usually occur together either with nickel and silver ores of similar composition or with minerals containing iron, nickel and copper. Following a series of roasting processes in which a series of selected fluxes are used to remove the silver and other metallic arsenides, another roasting operation using sodium chloride converts cobalt, nickel, copper and the remaining silver to their respective chlorides. The mixture is extracted with water to separate the soluble chlorides. The metallic copper is removed from the aqueous solution by reduction and the hydroxides of cobalt and nickel are then precipitated. The nickel is removed from the mixture by forming the volatile carbonyl, $\mathrm{Ni}(\mathrm{CO})_{3}$ in a separatory process involving a reduction of the nickel and reacting it with carbon monoxide. The resulting cobaltous oxide, $\mathrm{CoO}$, may be reduced to the metal with carbon or with aluminum. (11) 
Metalic cobalt is silvery white with a faint tinge of pink. It has a density of 8.9 and it melts at $1480^{\circ} \mathrm{C}$ and has a boiling point of $2900^{\circ} \mathrm{C}$. The atomic weight of cobalt is 53.94 .

Finely divided cobalt is pyrophoric. Cobalt in a more massive form is not attacked by air or water at temperatures below $300^{\circ} \mathrm{C}$; above $300^{\circ} \mathrm{C}$, it is readily oxidized in air. It combines with the halogens to form halides, but it does not combine directly with nitrogen; yet, it will form nitrides by decomposing ammonia at elevated temperatures. At temperatures above $225^{\circ} \mathrm{C}$, it will react with carbon monoxide to form the carbide, $\mathrm{Co}_{2} \mathrm{C}$. It will combine with most $01^{\circ}$ the other metalloids when heated or when it is in the molten state. It will form intermetallic compounds with other metals, such as aluminum, chromium, molybdenum, tin, vanadium, tungsten, zinc, nickel, and iron.

Dilute sulfuric, hydrochloric and nitric acids easily dissolve cobalt metal, but it is passivated by such strong oxidizing agents as the dichromates. Ammonium hydroxide and sodium hydroxide attack it very slowly.

\section{The Simple Cobalt Compounds}

Cobalt reacts less readily than iron with dilute acids. Its salts are either pink or blue in color. The pink color will change to blue either on heating, or on dehydration, or in the presence of concentrated acids. The most probable explanation for this color change is that divalent cobalt is pink as a cation, but blue as an anion. (12)

Cobalt compounds exhibit varied degrees of solubility in water and in other solubilizing agents. Table II lists the more common cobalt compounds and reports on their solubility in water and other agents. (13)

\section{The Complex Compounds of Cobalt}

As reported in Gmelins' Handbook, (14) $\mathrm{Co}^{+3}$ forms one of the largest groups of complex compounds known. The most numerous of these complexes are those of ammonia and the amines indicating that the most important donor atom is nitrogen. Carbon, oxygen, sulfur and the halogens are also 
Table II. Solubility of Common Cobalt Compounds
Compound

\section{Metal}

Acetate (ous)

Acetate (ic)

Benzoate (ous)

Bromate (ous)

Bromide (ous)

\section{Carbonate (ous) \\ Chlorate (ous)}

Perchlorate (ous)

Chloride (ous)

Chromate (ous)

Cyanide (ous)

Ferricyanide (ous)

Ferrocyanide (ous)
Formula

\section{Co}

$\mathrm{Co}\left(\mathrm{C}_{2} \mathrm{H}_{3} \mathrm{O}_{2}\right)_{2} \cdot 4 \mathrm{H}_{2} \mathrm{O}$

$\mathrm{Co}\left(\mathrm{C}_{2} \mathrm{H}_{3} \mathrm{O}_{2}\right)_{3}$

$\mathrm{Co}\left(\mathrm{C}_{7} \mathrm{H}_{5} \mathrm{O}_{2}\right)_{2} \cdot 4_{4} \mathrm{H}_{2} \mathrm{O}$

$\mathrm{Co}\left(\mathrm{BrO}_{3}\right)_{2} \cdot 6 \mathrm{H}_{2} \mathrm{O}$

$\mathrm{CoBr} 2 \cdot 6 \mathrm{H}_{2} \mathrm{O}$

$\mathrm{CoCO}_{3}$

$\mathrm{Co}\left(\mathrm{ClO}_{3}\right)_{2} \cdot 6 \mathrm{H}_{2} \mathrm{O}$

$\mathrm{Co}\left(\mathrm{ClO}_{4}\right)_{2} \cdot 6 \mathrm{H}_{2} \mathrm{O}$

$\mathrm{COCl}_{2} \cdot 6 \mathrm{H}_{2} \mathrm{O}$

$\mathrm{CoCrO}_{4}$

$\mathrm{Co}(\mathrm{CN})_{2} \cdot 2 \mathrm{H}_{2} \mathrm{O}$

$\mathrm{CO}_{3}\left[\mathrm{Fe}(\mathrm{CN})_{6}\right]_{2}$

$\mathrm{Co}_{2} \mathrm{Fe}(\mathrm{CHN})_{6} \cdot 7 \mathrm{H}_{2} \mathrm{O}$
Solubility in Water

very insoluble

very soluble

hydrolizes readily

very soluble

soluble

soluble

insoluble

very soluble

soluble

very soluble

insoluble

insoluble

insoluble

insoluble
Solubility in

Other Reagents

soluble in acids

soluble in acids, alcohol

soluble in glacial acetic acic

soluble in $\mathrm{NH}_{4} \mathrm{OH}$

soluble in acids, ether, alcohol

soluble in acids

soluble in alcohol

soluble in alcohol, acetone

soluble in alcohol

soluble in acids, $\mathrm{NH}_{4} \mathrm{OH}$

soluble in $\mathrm{KCN}, \mathrm{KCl}$, $\mathrm{NH}_{4} \mathrm{OH}$

soluble in $\mathrm{NH}_{4} \mathrm{OH}$

soluble in $\mathrm{KCN}$ 


\begin{tabular}{|c|c|c|c|}
\hline Fluoride (ous) & $\mathrm{CoF}_{2} \cdot 2 \mathrm{H}_{2} \mathrm{O}$ & soluble & soluble in $\mathrm{HF}$ \\
\hline Fluoride (ic) & $\mathrm{Co}_{2} \mathrm{~F}_{6} \cdot 7 \mathrm{H}_{2} \mathrm{O}$ & insoluble & \\
\hline Hydroxide (ous) & $\mathrm{Co}(\mathrm{OH})_{2}$ & slightly soluble & $\begin{array}{l}\text { soluble in acids, } \\
\text { ammonium salts }\end{array}$ \\
\hline Hydroxide (ic) & $\mathrm{Co}(\mathrm{OH})_{3}$ & slightly soluble & soluble in acids \\
\hline Iodate (ous) & $\mathrm{Cu}\left(\mathrm{IO}_{3}\right)_{2}$ & slightiy soluble & soluble in $\mathrm{HCl}, \mathrm{HNO}_{3}$ \\
\hline Iodide (ous) & $\mathrm{CoI}_{2}$ & very soluble & $\begin{array}{l}\text { soluble in alcohol, } \\
\text { acetone }\end{array}$ \\
\hline Nitrate (ous) & $\mathrm{Co}\left(\mathrm{NO}_{3}\right)_{2} \cdot 6 \mathrm{H}_{2} \mathrm{O}$ & very soluible & $\begin{array}{l}\text { soluble in alcohol, } \\
\text { acetone }\end{array}$ \\
\hline Oxalate (ous) & $\mathrm{CoC}_{2} \mathrm{O}_{4}$ & insoluble & soluble in acids, $\mathrm{NH}_{4} \mathrm{OH}$ \\
\hline Oxide (ous) & $\mathrm{CoO}$ & insoluole & soluble in acids \\
\hline Oxide (ous, ic) & $\mathrm{Co}_{3} \mathrm{O}_{4}$ & insoluble & soluble, in $\mathrm{H}_{2} \mathrm{SO}_{4}$ only \\
\hline Oxide (ic) & $\mathrm{Co}_{2} \mathrm{O}_{3}$ & insoluble & soluble in acids \\
\hline Orthophosphate (ous) & $\mathrm{CO}_{3}\left(\mathrm{PO}_{4}\right)_{2}$ & insoluble & $\begin{array}{l}\text { soluble in } \mathrm{H}_{3} \mathrm{PO}_{4} \text {, } \\
\mathrm{NH}_{4} \mathrm{OH}\end{array}$ \\
\hline Phosphide & $\mathrm{CO}_{2} \mathrm{P}$ & insoluble & soluble in $\mathrm{HNO}_{3}$ \\
\hline Sulfate (ous) & $\mathrm{CoSO}_{4} \cdot \mathrm{H}_{2} \mathrm{O}$ & soluble & \\
\hline Sulfate (ic) & $\mathrm{CO}_{2}\left(\mathrm{SO}_{4}\right)_{3} \cdot 18 \mathrm{H}_{2} \mathrm{O}$ & soluble & soluble in $\mathrm{H}_{2} \mathrm{SO}_{4}$ \\
\hline Sulfide, mono- & $\cos$ & slightly soluble & $\begin{array}{l}\text { soluble in acids, } \\
\text { alcohol }\end{array}$ \\
\hline Sulfide, di- & $\operatorname{CoS}_{2}$ & insoluble & $\begin{array}{l}\text { soluble in } \mathrm{HNO}_{3} \text {, aqua } \\
\text { regia }\end{array}$ \\
\hline
\end{tabular}

(Table continued on following page.) 
Table II (Contimued)

Compound

Sulfide, sesqui- (ic)

Tartrate (ous)

Thiocyanate (ous)

Tungstate (ous)

Amnonium cobalt

orthophosphate (ous)

Armonium cobalt

sulfate (ous)

Potassium cobalt carbonate

acid (ous)

Potassium cobaltinitrite

Potassium cobalt

malonate (ous)

Potassium cobalt

$$
\text { sulfate (ous) }
$$

Potassium cyanocobaltate(III)

Potassium cyanocobaltate(II)

Fotassium sodium

nitrocobaltate(III)

Sodium nitrocobaltate(III)

$\mathrm{Na}_{3} \mathrm{Co}\left(\mathrm{NO}_{2}\right)_{6}$
Formula

$\mathrm{CO}_{2} \mathrm{~S}_{3}$

$\mathrm{CoC}_{4} \mathrm{If}_{4} \mathrm{O}_{6}$

$\mathrm{Co}(\mathrm{SCII})_{2} \cdot 3 \mathrm{H}_{2} \mathrm{O}$

$\mathrm{CO}_{4} \mathrm{OO}_{4}$

$\mathrm{NH}_{4} \mathrm{COPO}_{4} \cdot \mathrm{H}_{2} \mathrm{O}$

$\left(\mathrm{NH}_{4}\right)_{2} \mathrm{SO}_{4} \cdot \mathrm{COSO}_{4} \cdot 6 \mathrm{H}_{2} \mathrm{O}$

$\mathrm{KHCO}_{3} \cdot \mathrm{COCO}_{3} \cdot 4 \mathrm{H}_{2} \mathrm{O}$

$\mathrm{K}_{3} \mathrm{Co}\left(\mathrm{NO}_{2}\right)_{6}$

$\mathrm{K}_{2} \mathrm{Co}\left(\mathrm{C}_{3} \mathrm{H}_{2} \mathrm{O}_{4}\right)_{2}$

$\mathrm{K}_{2} \mathrm{SO}_{4} \cdot \mathrm{COSO}_{4} \cdot 6 \mathrm{H}_{2} \mathrm{O}$

$\mathrm{K}_{3} \mathrm{Co}(\mathrm{Cr})_{6}$

$\mathrm{K}_{4} \mathrm{Co}(\mathrm{CN})_{6}$

$\mathrm{K}_{2} \mathrm{NaCo}\left(\mathrm{NO}_{2}\right)_{6} \cdot \mathrm{H}_{2} \mathrm{O}$ insoluble

slightly soluble

soluble

insoluble

insoluble

soluble

decomposes

slightly soluble

soluble mineral acids Other Reagents

decomposes in acids

soluble in dilute

acios

soluble in hot conc.

acids

soluble acids
Solubility in Water

Solubility in

soluble acids, alcohol

soluble

soluble

soluble

0.07

slightly soluble insoluble aluminum

insoluble aluminum and ether

insoluble aluminum

soluble dilute acid,

alcohol 
important donor atoms. The coordination number $\mathrm{O}^{-1} \mathrm{Co}^{+3}$ is six, and most of the trivalent cobalt complexes are stable. In contrast, $\mathrm{Co}^{+2}$ has a coordination number of either 4 or 6 , and the $\mathrm{Co}^{+2}$ complexes are relatively unstable towards oxidation. The ammine complexes can be easily oxidized in air, and the cobaltocyanides are oxidized rapidly in air or in water.

Many aquo-halo complexes are known and exist in varied shades of red and blue. The aquo complex, $\left[\mathrm{Co}\left(\mathrm{H}_{2} \mathrm{O}\right)_{6}\right]^{+2}$ is pink, but when a halide is introduced into the system, a blue-colored complex anion, $\left(\operatorname{CoX}_{4}\right)^{-2}$ is produced. Usually, the blue color is more intense and it can completely mask the color of a larger concentration of the pink complex. This phenomenon apparently results from the fact that cobaltous halides are normally pink in dilute aqueous solutions, but when heated or in concentrated solution will turn blue. Table IIr lists some of the cobalt complexes (13) showing their solubillty in water and various solvents.

\section{The Organometallic Compounds of Cobalt}

Cobalt, like iron and nickel, does not appear to produce true organometallic compounds in that such reactions proceed largely with hydrocarbon evolution, metal deposition, abnormal coupling and other unusual reactions. (15) Kharasch and Fields ${ }^{(16)}$ in their investigation on the effects of metallic halides on Aryl-Grignard Reagents and organic halides explain that these effects require transitory intermediate organocobalt compounds of the type RCoX. Briggs and Polya ${ }^{(17)}$ have reacted $\alpha$ - and $\beta$-naphthylmagnesium halides with cobaltous halides to produce complex condensates of the type, $\mathrm{C}_{10} \mathrm{H}_{7} \mathrm{CoX}_{3} \cdot \mathrm{RCoX}_{3}$ compounds have also been prepared by methyl-, ethyl-, n-propyl-, and i-propylmagnesium iodide and phenylmagnesium bromide reactions upon cobaltous halides. (18) Biscyclopentadienylcobalt and bisindenylcobalt compounds have also been prepared. (19) These compounds are readily oxidized to monovalent cations and their salts are usually colored, water-soluble compounds.

\section{B. The Analytical Chemistry of Cobalt}

As pointed out elsewhere in this monograph, the use of a known amount of inactive cobalt carrier in a separation method almost always makes it 
Table III. Some Complex Cobalt Compounds*

\begin{tabular}{lll}
\multicolumn{1}{c}{ Formula } & & \multicolumn{2}{c}{ Solubility } \\
$\mathrm{CoCl}_{2} \cdot 2 \mathrm{NH}_{3}$ & soluble & soluble $\mathrm{NH}_{4} \mathrm{OH}$ \\
{$\left[\mathrm{Co}\left(\mathrm{NH}_{3}\right)_{6}\right] \mathrm{Cl}_{2}$} & soluble & slightly soluble $\mathrm{HC}^{\prime}$ \\
{$\left[\mathrm{Co}\left(\mathrm{NH}_{3}\right)_{5} \mathrm{H}_{2} \mathrm{O}\right] \mathrm{Cl}_{3}$} & soluble & conc. $\mathrm{H}_{2} \mathrm{SO}_{4}$ \\
{$\left[\mathrm{Co}\left(\mathrm{NH}_{3}\right)_{5} \mathrm{Cl}\right] \mathrm{Cl}_{2}$} & slightly soluble & \\
$\mathrm{Co}\left(\mathrm{NH}_{3}\right)_{6} \mathrm{Cl} l_{3}$ & & \\
{$\left[\mathrm{Co}\left(\mathrm{NH}_{3}\right)_{6}\right]\left(\mathrm{ReO}_{4}\right)_{3} \cdot 2 \mathrm{H}_{2} \mathrm{O}$} & very slightly soluble
\end{tabular}

* Cobalt also forms polynuclear complexes. In these compounds 2,3 or 4 cobalt atoms are linked by $\mathrm{OH}, \mathrm{O}_{2}$ or $\mathrm{NH}_{2}$. 
possible to obtain the cobalt carrier in a weighable form in the final stage of the separation procedure used. Two things are achieved if this is done. The radionuclide is concentrated into a small mass for the radioactivity measurements, and the carrier is obtained as a weighable compound which can be used to determine any loss of the "carrier" during the analysis.

The choice of acceptable gravimetric forms for a cobalt determination is extensive and somewhat controversial. Duval $(20)$ in his thermogravimetric investigations states that there are at least 30 gravimetric methods avallable for the determination of cobalt. In his evaluation of these methods, he indicates that the most suitable compounds for determining cobalt are cobalt ammonium phosphate, $\mathrm{CoNH}_{4} \mathrm{PO}_{4} \cdot \mathrm{H}_{2} \mathrm{O} ;(21,22)$ potassium cobaltin1trate, $2 \mathrm{~K}_{2} \mathrm{Co}\left(\mathrm{NO}_{2}\right)_{6} \cdot 3 \mathrm{H}_{2} \mathrm{O} ;{ }^{(23)}$ silver hexacyanocobaltate, $\mathrm{Ag}_{3} \mathrm{Co}(\mathrm{CN})_{6} ;{ }^{(24)}$ cobalt tetrath1ocyanatomercurate, $\mathrm{CoHg}(\mathrm{CNS})_{4} ;(25-29)$ cobalt anthranilate, $\mathrm{Co}\left(\mathrm{NH}_{2} \cdot \mathrm{C}_{6} \mathrm{H}_{4} \cdot \mathrm{CO}_{2}\right)_{2} ;(30,31)$ cobalt 5-bromoanthranilate, $\mathrm{Co}\left(\mathrm{NH}_{2} \cdot \mathrm{C}_{6} \mathrm{H}_{3} \mathrm{Br} \cdot \mathrm{CO}_{2}\right) ;$; (32)

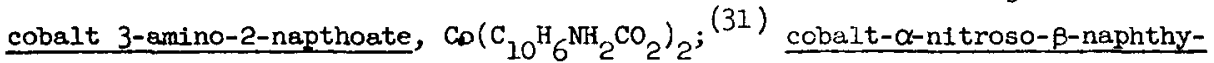
lamine, $\mathrm{Co}\left(\mathrm{C}_{10} \mathrm{H}_{7} \mathrm{ON}_{2}\right)_{3} ;^{(33)}$ cobalt oxine, $\mathrm{Co}\left(\mathrm{C}_{9} \mathrm{H}_{6} \mathrm{ON}\right)_{2} ;{ }^{(34,35)}$ cobalt oxide, $\mathrm{Co}_{2} \mathrm{O}_{3}$, obtalned by the Ignition of the phenylthiohydantoic acid complex; (36) or cobaltic oxide, $\mathrm{Co}_{3} \mathrm{O}_{4}$, obtained by the ignition of yeilow mercury oxide complex. (37) Anand and Dechmukh ${ }^{(38)}$ report that cobalt tellurite, $\mathrm{CoTeO}_{3}$, is also a good gravimetric form for determining cobalt. Williams (39) records that the precipitation of cobalt as the metal by the reduction of $\mathrm{CO}_{3} \mathrm{O}_{4}$ with hydrogen is a recommended gravimetric form. However, certain limitations exist in that the reduced metal is very pyrophoric and sometimes contains appreciable quantities of unreduced oxide.

Very often when one of these gravimetric forms is employed, it is preceded by ane of several other methods of chemical separation such as solvent extraction, ion exchange, precipitation, or electrolysis. The information that follows generally reports on current ideas used in isolating and determining cobalt. A combination of several isolation methods may be used. However, it should not be inferred that it is always necessary to radiochemically separate the desired cobalt isotope in a precipltable form for the radioactivity measurements. Sometimes it would be sufficient to accept and use, for example, an aliquot of the eluate from 
an ion-exchange separation column or one of the phases obtained in solvent extraction, or a portion of a paper chromatogram in the radioactivity measurements.

Williams (39) also provides an excellent summary of the advances made in the analytical chemistry of cobalt. The authors of this monograph feel that much of this information is pertinent to the separation techniques that follow and they have attempted to emphasize much of the information given in this particular review.

\section{Separations by Precipitation}

The separation of cobalt from other elements can be effected with bydrogen sulfide, ammonium sulfide, basic acetate, succinate, barium carbonate, zinc oxide, potassium hydroxide and bromine, ether-hydrochloric acid, and cupferron. (40) Cos can be coprecipitated with $\mathrm{SnS}_{2}$ and carried down when low-solubility sulfides are precipitated in dilute or concentrated mineral acids. (40) special care must also be taken to prevent its coprecipitation with zinc sulfide; however, the addition of a small amount of acrolein and gelatin to the solution before its treatment with hydrogen sulfide will reduce the coprecipitation effects. (4I)

Britton (42) has shown that if there is a sufficient difference between the values of $\mathrm{pH}$ at which two metal hydroxides are precipitated with ammonium hydroxide, the metals may often be separated by maintaining the pH of the solution at such a value so that the weaker one will be precipitated first. Buffer solutions, usually weak acids or one of their salts, and heating are used to effect the hydrolysis. Such metals as chromium, zinc, uranium, aluminum, tin, iron (as $\mathrm{Fe}^{+3}$ ), zirconium and titanium precipitate at lower $\mathrm{pH}$ values than cobalt, which precipitates at a pH of 6.8 . Magnesium, silver, manganese, mercury, and some of the rare earths precipitate at pH values greater than 7.0 .

Cobalt cannot easily be separated from such elements as iron, aluminum, copper and nickel by ammonium hydroxide. Iundell and Knowles (43) report that even though small amounts of cobalt are involved and double precipitations made, the amount of cobalt retained by the hydroxide precipitate 
of iron and aluminum is appreciable. Iron may be effectively removed from cobalt (and nickel) as ferric phosphate if the precipitation is made from an acetic acid solution. (44) Titanium, zirconium and hafnium can be separated from cobalt as phosphates by treating an acetic acid solution of the ions ( $\mathrm{pH} 3.5)$ with ammonium phosphate. $(44,45)$ Cobalt can be separated from iron, aluminum, titanium, and zirconium by precipitating them with an aqueous suspension of zinc oxide. (46) Chromium, vanadium, and tungsten can also be removed by a zinc oxide precipitation after the solution has been oxidized with nitric acid. (47) Chromium and such elements as aluminum, arsenic, molybdenum, tungsten and vanadium can be separated from cobalt by precipitations with sodium peroxide in the presence of bromine or some other oxidizing agent. (48) Chromium can also be separated from cobalt by precipitating $C O S$ in the presence of ammonium tartrate. (49) Iron, nickel and zinc sulfide also precipitate. Cobalt does not form a cupferrate and can be separated from such elements as iron, titanium, vanadium, zirconium, tin, antimony, and bismuth by forming the cupferrates of these elements. (50) The cobalt can be recovered either by filtration or by solvent extraction. Burgess, (51) von Knorre, (52) and Mayr and Feigl (53) report on the use of $\alpha$-nitroso- $\beta$-naphthol (sometimes called l-nitroso-2-naphthol) in glacial acetic acid to separate cobalt from such elements as aluminum, beryllium, lead, cadmium, manganese, mercury, arsenic, antimony, zinc, calcium, magnesium and moderate amounts of nickel. Phosphates, arsenates, and ammonium salts do not interfere whereas nitric acid must be absent before the precipitation is made. Iron, copper, bismuth, silver, chromium, zirconium, titanium, vanadium, and tin also interfere. If a considerable amount of nickel is present, the cobaltinitroso- $\beta$-naphthol precipitate, $\left[\mathrm{C}_{10} \mathrm{H}_{6} \mathrm{O} \text { (NO) }\right]_{3} \mathrm{Co}$, should be ignited, dissolved in hydrochloric acid and a reprecipitation made. The interferences from large amounts of nickel can also be eliminated by making an initial separation of nickel by adding an alcoholic solution of dimethylglyoxime to an acetic acid-sodium acetate solution of the ions. (54) The cobalt ions are soluble, and the nickel dimethylglyoxime precipitate can be removed by filtering the mixture. If cobalt is to be determined in the presence of large amounts of manganese by a precipitation with $\alpha$-nitroso- 
f-naphthol, mach of the manganese can be removed by precipitating it as the dioxide by adding potassium chlorate to a boiling nitric acid solution. (55) The manganese dioxide is separated from the mixture by filtration.

The traditional method of determining cobalt in ferrous metals is based upon its precipitation with $\alpha$-nitroso-e-naphthol, but Bogshaw (56) reports that nitroso-R-salt is a much more reliable reagent. Nitrosonaphthol has also been used in separating cobalt (as both the stable and radioactive species) from neutron-irradiated steel. (57) The nitrosonaphthol precipitates, i.e., of the $\left[\mathrm{C}_{10} \mathrm{H}_{6} \mathrm{O}(\mathrm{NO})\right]_{3}$ types, may be dried and weighed in that Lorm, or they may be ignited to the oxide, $\mathrm{Co}_{3} \mathrm{O}_{4}$, or converted to the sulfate, $\mathrm{CoSO}_{4}$, before weighing.

Cobalt may also be separated as the sulfide, CoS, from a basic solution and can be converted to ammonium cobalt phosphate, $\mathrm{NH}_{4} \mathrm{CoPO}_{4} \cdot \mathrm{H}_{2} \mathrm{O}$, which after washing can be ignited to the pyrophosphate, $\mathrm{Co}_{3} \mathrm{P}_{2} \mathrm{O}_{7}$, for weighing. $(21,22,53)$ However, traces of cobalt are orten found in the filtrate. As an alternative, the sulfide, Cos, can be directly ignited to the oxide, $\mathrm{Co}_{3} \mathrm{O}_{4}$.

According to H1llebrand and co-workers, (40) the method most often employed to separate cobalt from interfering elements is the converse of the cobaltinitrite method for potassium, i.e., the potassium nitrite method. In this method, first suggested by Fischer, ${ }^{(59)}$ an excess of potassium ritrite in acetic acid is added to quantitatively precipitate the cobalt. Some recent applications of the use of potassium nitrite in separating cobalt include those reported by Brooksbank, et al., ${ }^{(60)}$ Kallmann, (6I) and Smith, et al. (62) Brooksbank, et al., $(60)$ have used potassium cobaltinitrite dried at $110^{\circ} \mathrm{C}$ as the weighing form of cobalt separated from neutron-irradiated aluminumbase alloys. Kallmann $(61)$ has used tartaric acid to complex interfering elements (especially nickel) in separating cobalt by the potassium nitrite method. Smith, et al., (62) report on the use of potassium nitrite to separate radioactive cobalt from radioactive corrosion products. With regard to the use of this method, Broughton, et al., (63) report that explosive reactions can occur if the cobaltinitrite solution is reheated after standing for some time. Horowitz ${ }^{(64)}$ postulates that these explosions 
result from the formation of nitralic acid salts. It should be noted here that Kallman (61) suggests that the cobaltinitrite method is good for separatIng cobalt from other metals, but the final gravimetric determination of cobalt should be made by some other method.

Baker and McCutchen ${ }^{(65)}$ report on the use of quaternary anmonium hydroxide as a precipitant for cobalt. Cobalt can also be precipitated from a hot solution with $\underline{\mathrm{N}}$-benzoylphenyl-hydroxylamine ${ }^{(66)}$ and converted to $\mathrm{CoSO}_{4}$ as the weighing form. Nickel will interfere in this separation. Also, copper is an interference; however, it can be removed by a precipitation at $\mathrm{pH} 4$ in the presence of the reagent; cobalt (and nickel) require a pH from 5.5 to 6.5 for a precipitate to result. Bivalent cobalt can be separated from ferrous materials by precipitating it with acridine ${ }^{(67)}$ from a hydrochloric acid solution containing excess ammonium thiocyanate. Cobalt can be separated from tungsten by treating a neutral or slightly alkaline solution with tartaric acid, amonium thiocyanate and an excess of pyridine. (68)

Andrew and Gentry ${ }^{(69)}$ have recently evaluated the advantages and shortcomings of methods proposed for the analysis of cobalt. As a result, they consider the tetraphenylarsonium cobaltothiocyanate method the best method. The precipitation of cobalt as the tellurite ${ }^{(38)}$ by a measured excess of potassium tellurite and its determination gravimetrically as the cobalt tellurite, $\mathrm{CoTeO}_{3}$, was also considered to be a favorable method.

Cobalt can be separated from strong acid solutions by treatments with sodium nitrite ${ }^{(70)}$ to form $\mathrm{Co}\left(\mathrm{NH}_{2}\right)_{6} \cdot \mathrm{Co}\left(\mathrm{NO}_{2}\right)_{6}$. The sodium nitrite oxidizes $\mathrm{Co}$ (II) to $\mathrm{Co}$ (III) to form $\mathrm{Na}_{3} \mathrm{Co}\left(\mathrm{NO}_{2}\right)_{6}$. After the mixture is carefully shaken to remove the nitrite formed through interactiou of excess acid with the $\mathrm{NaNO}_{2}$, an excess of a saturated cold solution of $\mathrm{Co}\left(\mathrm{NH}_{3}\right)_{6} \mathrm{Cl}_{3}$ is added dropwise to form a yelloy insoluble crystalline precipitate. Cobalt can be determined in the presence of nickel, calcium, copper, strontium, zinc, manganese, mercury, lead, cadmium and barium by this method. The lons of potassium and ammonium are major interferences.

As a preliminary study in an investigation concerned with the decontamination $^{(71)}$ of radioactive laboratory waste water by coprecipitation, 
the behavior of very small quantities of radioactive ions with different voluminous precipitants was studied. The radoactive ions of $\mathrm{PO}_{4}$ (III), $\mathrm{Co}(\mathrm{II})$ and $\mathrm{Cs}(\mathrm{I})$ were precipitated from solution by the use of iron oxyhydrate, aluminum oxyhydrate, copper ferrocyanide and iron ferrocyanide reagents. In this report, data is given on the dependence of such factors as $\mathrm{pH}$, precipitant concentration, and equivalent ratio of the precipitant compounds formed in the case of each precipitant used.

Rubeanic acid $(72)$ will precipitate cobalt (as well as copper, nickel, zinc, and cadmium) from interfering lons found after the acid dissolution of rock specimens. Cobalt can be separated from nickel by forming a stable cyanide complex in acid solution. (24) After decomposing the $\mathrm{K}_{2} \mathrm{Ni}(\mathrm{CN})_{4}$, silver nitrate is added to the solution and the resulting precipitate of $\mathrm{Ag}_{3} \mathrm{Co}(\mathrm{CN})_{6}$ can be aried at $136^{\circ}$ and weighed.

Other precipitation methods studied for the separation of cobalt include those based on the use of such reagents as mercuric chlorideammonium thiocyanate, $(25-29)$ dinitroresorcinol, (73) anthranilic acid, $(30,31)$ 5-bromoanthranilic acid, (32) 8-hydroxyquinoline, $(34,35)$ phenylthiohydantic acid, (36) diphenylthiohydantoin, (74) mercuric iodide-ammonium hydroxide, $(75)$ benzoquinaldinic acid, $(76)$ isonitrosodimedone, $(77)$ and benziminazole. (78) Each of these methods have their merits; however, in some instances, the analysis conditions influence the ease with which a separation of cobalt can be obtained.

\section{Separations by Jlectrodeposition}

According to Williams, ${ }^{(39)}$ many investigators consider the electrodeposition methods as the best methods where large umounts of cobalt are involved and high accuracy is desired. There are many diverse methods ind each method considers variables concerned with such factors as the chemical composition of the electrolyte, the time of electrolysis, current density, temperature, type of electrode, rate of stirring and the $\mathrm{pH}$ of the solution. In almost all cobalt electrolytic methods and depending on the sample, electrolysis may be preceded by an isolation of the cobalt from interfering elements either by precipitation, (79) with such agents as zinc oxide, $\alpha-$ nitroso- $\beta$-naphthol, or phosphate ions, or by anion-exchange resins. (80) 
Most electrolytic separations for cobalt are based upon the use of ammonical solutions as electrolytes. In order to prevent anodic deposits of cobalt and the oxidation of the cobaltous-ammine 1ons, small amounts of reducing agents such as hydrazine sulfate ${ }^{(81)}$ and sodium bisulfite ${ }^{(82)}$ are added to the solution during electrolysis. Brophy ${ }^{(83)}$ reports on the use of such agents during an analysis at a high current density. Other variations, concerned with the use of reducing agents, as well as current density and time required for deposition, have been reported by Young and Hall, (44) Kallman, (61) and Scott and Furman. (84)

Lingane and Page ${ }^{(85)}$ have shown that cobalt and nickel can be separated electrolytically by utilizing an aqueous pyridine solution with hydrazine to depolarize the platinum anode. The nickel is removed at a controlled potential of -0.95 volt and a solution $\mathrm{pH}$ of from 5 to 7 , after which the cobalt is deposited at -1.20 volts without any interferences.

Torrance ${ }^{(86)}$ first reported that cobalt could be deposited upon an anode at $\mathrm{pH}_{5}$ as $\mathrm{Co}_{2} \mathrm{O}_{3}$. Salyer and Sweet $(87-89)$ have also shown that hydrated cobaltic oxide could be deposited on an anode. Solutions containing a known amount of radioactive $\mathrm{Co}^{60}(5.3 y)$ were used in this work and the concentration of cobalt deposited upon the anode determined by an isotope dilution technique.

The determination of small amounts of cobalt by internal electrolysis has been reported by Schleicher. (90) Also, information on the use of a rotating mercury electrode in determining cobelt has been presented by Tutundzic and Stojkovic. (91)

\section{Separations by Solvent Extraction}

Solvent extraction methods used as separation methods for other analysis techniques can often be adapted for use in radiochemistry and can be quite useful in separating the desired cobalt radionuclide from a sample by either a carrier-free or carrier radiochemical method. Morrison and Freiser $(92)$ have recently reviewed the applications of ion association and chelate complex systems to the determination of most of the elements. Some of these systems are applicable for use as separation processes in the radiochemistry of the cobalt radionuclides. 


\section{a. Ion Association System}

Kitahara ${ }^{(93)}$ and Bock and Herrmann $(94)$ have shown that cobalt $\left(\mathrm{Co}^{+2}\right)$ will not extract with ethyl ether from HF solutions of varying concentrations. $\mathrm{Sn}^{+2}$ and $\mathrm{Sn}^{+4}$ are completely extracted; $\mathrm{As}^{+3}, \mathrm{Sb}^{+3}, \mathrm{Se}^{+4}$, and $\mathrm{Mo}^{+6}$ partially extract; cobalt (as well as $\mathrm{Ni}^{+2}, \mathrm{Cr}^{+3}, \mathrm{Mn}^{+2}, \mathrm{~K}^{+1}, \mathrm{Ti}^{+4}, \mathrm{Zr}^{+4}$, $\mathrm{Ga}^{+3}, \mathrm{Ag}^{+1}, \mathrm{U}^{+6}, \mathrm{Bi}^{+6}, \mathrm{Te}^{+4}, \mathrm{Ca}^{+2}$, and $\left.\mathrm{Os}^{+6}\right)$ do not extract.

Carwin and Hixson ${ }^{(95)}$ have shown that cobalt $\left(\mathrm{Co}^{+2}\right)$ can be separated from nickel by extracting $10 \mathrm{M} \mathrm{HCl}$ and $0.85 \underline{\mathrm{M} \mathrm{CaCl}} 2$ solutions with 2-octanol. Bock, et al. $(96)$ have shown that less than $0.1 \% \mathrm{Co}^{+2}$ will be extracted by ethyl ether from a metal bromide solution (0.1 $\mathrm{M}$ to $6 \mathrm{M} \mathrm{HBr}$ ); whereas, $\mathrm{Sb}^{+5}, \mathrm{Fe}^{+3}, \mathrm{Hg}^{+2}, \mathrm{Au}^{+3}, \mathrm{In}^{+3}, \mathrm{TI}^{+3}$, are quantlatively extracted. Varying amounts of $\mathrm{Ga}^{+3}, \mathrm{Sn}^{+2}, \mathrm{Sn}^{+4}, \mathrm{Sb}^{+3}, \mathrm{Se}^{+4}$, and $\mathrm{Mo}^{+6}$ will extract depending upon the $\mathrm{HBr}$ concentration. $\mathrm{Cu}^{+2}, \mathrm{NI}^{+2}, \mathrm{Zn}^{+2}, \mathrm{Cd}^{+2}, \mathrm{v}^{+5}$, and $\mathrm{Te}^{+4}$ do not extract appreclably. In another study, ${ }^{(97)}$ the extractability of certain metal bromides from aqueous solutions containing $\mathrm{HBr}$ and/or $\mathrm{NH}_{4} \mathrm{Br}$ with methyl isobutyl ketone and methyl ethyl ketone as solvents have been studied. $\mathrm{Fe}^{+3}$ can be separated from $\mathrm{Mn}^{+2}, \mathrm{Al}^{+3}, \mathrm{Co}^{+2}$, and $\mathrm{Ni}^{+2}$ under these conditions. $\mathrm{Co}^{+2}\left(\mathrm{Mn}, \mathrm{Ni}, \mathrm{Cr}, \mathrm{V}, \mathrm{Al}, \mathrm{Fe}^{+2}, \mathrm{Ti}, \mathrm{Zr}, \mathrm{Pb}, \mathrm{Th}, \mathrm{Ga}, \mathrm{Be}, \mathrm{U}\right.$ and the noble metals) do not extract into ethyl ether from $6.9 \mathrm{M}$ HI solutions. (98) $\mathrm{Sb}^{+3}, \mathrm{Hg}^{+2}, \mathrm{Cd}^{+2}, \mathrm{Au}^{+3}$, and $\mathrm{Sn}^{+2}$ extract quantitatively into ethyl ether under the same conditions.

Oxygen-containing solvents can be used in the solvent extraction of $\mathrm{Co}^{+2}$ (as a blue complex) from $\mathrm{NH}_{4} \mathrm{SCN}$ solutions of various concentrations. $\mathrm{Co}^{+2}$ (as well as $\mathrm{Be}, \mathrm{Zn}, \mathrm{Co}, \mathrm{Sc}, \mathrm{Ga}, \mathrm{In}, \mathrm{Ti}^{+3}, \mathrm{Fe}^{+3}, \mathrm{Sn}^{+4}$, and $\mathrm{Mo}^{+\mathrm{t}}$ ) extract into ethyl ether ${ }^{(99)}$ or amyl alcohol ${ }^{(100)}$ and can be separated from such elements as $\mathrm{Al}^{+3}, \mathrm{v}^{+4}, \mathrm{U}^{+6}, \mathrm{Li}^{+1}, \mathrm{Cu}^{+2}, \mathrm{Cd}^{+2}, \mathrm{Hg}^{+2}$, $\mathrm{Ge}^{+4}, \mathrm{As}^{+3}, \mathrm{As}^{+5}, \mathrm{Sb}^{+3}, \mathrm{Bi}^{+2}, \mathrm{Cr}^{+3}, \mathrm{Ni}^{+2}$, and $\mathrm{Pd}^{+2}$. These elements onl partially extract or do not extract at all. $\mathrm{Co}^{+2}, \mathrm{Ni}^{+2}$, and $\mathrm{Cu}^{+2}$ form water-insoluble cyanate complexes in a $\mathrm{NH}_{4} \mathrm{SCN}$ system that can be dissolved in and extracted with chloroform. (101)

$\mathrm{Co}^{+2}$ (as well as $\mathrm{NI}^{+2}$ ) precipitates at the interface in extracting alkaline aqueous solutions that contain $\mathrm{Cu}, \mathrm{Mn}, \mathrm{Fe}, \mathrm{Pd}$, and $\mathrm{Ru}$ with 5\% $\mathrm{C}_{9} \mathrm{H} 19^{\mathrm{COOH}}$ (n-capric acid) in ethyl acetate. (102) $\mathrm{Cu}^{+2}$ is quantitatively 
extracted under these conditions; $\mathrm{Mn}, \mathrm{Fe}, \mathrm{Ni}, \mathrm{Co}, \mathrm{Pd}$, and $\mathrm{Ru}$ interfere. When butyric acid in benzene is used, only $\mathrm{Cu}, \mathrm{Mn}$, and $\mathrm{Fe}$ extract.

Methyldioctylamine and tribenzylamine have been used to extract $\mathrm{Zn}$ from cobalt (and other metals of the first transition series) in dilute $\mathrm{HCl}$ solutions. (103) Only $0.4 \% \mathrm{Co}$ and $>99 \% \mathrm{Zn}$ was extracted from a $2 \mathrm{M}$ $\mathrm{HCl}$ solution by a solution containing $8 \mathrm{~g}$ of methyldioctylamine (MDOA) per $100 \mathrm{ml}$ of trichlorobenzene. At a higher $\mathrm{HCl}$ concentration (10 N), $85.4 \%$ of the cobalt and $100 \%$ of the zinc extracted. Solutions of MDOA in xylene and in chloroform also quantitatively extract zinc from cobalt under the same conditions. These studies also include an investigation of the extraction of $\mathrm{Cr}^{+3}, \mathrm{Mn}^{+2}, \mathrm{Fe}^{+3}, \mathrm{Ni}^{+2}$, and $\mathrm{Cu}^{+1}$ under the same conditions. Varied degrees of extraction and separation of these elements from cobalt (and zinc), depending upon conditions and organic agents used, were found.

Acid solutions and extractions with high molecular weight amines $(104,105)$ have been used to separate iron from cobalt. Only negligible amounts of Co (as well as $\mathrm{Zn}, \mathrm{Al}, \mathrm{Na}, \mathrm{Mg}, \mathrm{Ca}, \mathrm{Ni}, \mathrm{Cu}, \mathrm{Mn}$, and $\mathrm{Cr}^{+3}$ ) are extracted under these conditions.

vobalt $\left(\mathrm{Co}^{+2}\right)$ anionic thiocyanate complexes, as well as those of $\mathrm{Fe}^{+3}, \mathrm{Mo}^{+5}$, and $\mathrm{Cu}^{+2}$, have been shown to form salts with triphenylmethylarsonium chloride that are extractable into o-dichlorobenzene. $(106,107)$ A mixture of $35 \%$ amyl alcohol $-65 \%$ ether can be used to extract the thiocyanate complex of cobalt to separate cobalt from other elements. (108) Iron, nickel, copper, and zinc also form thiocyanates that are partially extracted in this system. The extraction of $\mathrm{Fe}^{+3}$ can be prevented by adding citric acid or reducing the $\mathrm{Fe}^{+3}$ to $\mathrm{Fe}^{+2}$. Nickel, copper, and zinc do not interfere in the determination of cobalt as the nitroso-R salt complex since cobalt can be extracted as a thiocyanate from a slightly acid solution with polyethylene glycol and methylene chloride; (109) Iron, nickel, and zinc do not extract. The cobalt thiocyanate complex can also be extracted with acetylacetone. (110)

Potratz (111) has shown that at least $95 \%$ of the cobalt tetraphenylarsonium chloride formed in an acta solution can be extracted into chloro- 
form. The use of a $50 \% \mathrm{KSCN}$ and $\mathrm{NH}_{4} \mathrm{~F}$ mixture masks $\mathrm{Fe}^{+3}$ and $\mathrm{U}^{+6}$ and prevents their extraction. The reduction of $\mathrm{Cu}^{+2}$ to $\mathrm{Cu}^{+1}$ and the use of $10 \%$ KI solution eliminates the copper interference. None of the other metals interfere.

The heterocyclic polyamine, 2,2',2"-terpyridyl, forms a cobalt complex which can readily be extracted into nitrobenzene. (112) $\mathrm{Cu}$, $\mathrm{Fe}$, and $\mathrm{Ni}$ interfere in this system.

\section{b. Chelate Compound Systems}

Acetylacetone in chlorororm does not form an extractable chelate (113) with either $\mathrm{Co}^{+2}$ or $\mathrm{Ni}^{+2}$ in highly acid solutions; however, the $\mathrm{Co}^{+3}$ chelate can be easily extracted $(114,115)$ and this system can be used to separate cobalt from nickel. Other metals, such as $\mathrm{Fe}, \mathrm{Mn}, \mathrm{V}^{+4}, \mathrm{Zn}$, and $\mathrm{Zr}$ also extracu under these same conditions ( $\mathrm{pH}$ 6-9).

Cobalt can be extracted from aqueous solutions with 8-quinolinol (oxine) i chloroform. $(116,117)$ Masking agents such as cyanide $(118,119)$ can retard the extraction of $\mathrm{Fe}, \mathrm{Cu}, \mathrm{Mo}$, and $\mathrm{Ni}$. It has also been shown (120) that the use of sodium ethylenediaminetetraacetate, EDTA, as a masking agent in oxine extractions inhibits the extraction of $\mathrm{Co}$ (and $\mathrm{AI}, \mathrm{Fe}^{+3}, \mathrm{Mn}$ and $\mathrm{Ni}$ ) at $\mathrm{pH} 8$ or above. When calcium ethylenediaminetetraacetate is used, it is possible to completely inhibit the extraction of Co (as well as Al and $\mathrm{Mn}$ ) at a $\mathrm{pH}$ of 6 . In an earlier study, (121) it was shown that a solution containing 1\% 8-quinolinol in chloroform will extract up to 10 Ing of Co from aqueous solutions having a hydrogen ion concentration in excess of $\mathrm{pH} 3.5 . \mathrm{Al}^{+3}$ and $\mathrm{NI}^{+4}$ interfere in these extractions. Cobalt will not extract below a $\mathrm{pH}$ of 3.5 ; whereas, $\mathrm{Fe}, \mathrm{Cu}$ and $\mathrm{Bi}$ do.

In a thermodynamic study of some coordination complexes of metal ions with diprotic nitrogen compounds, (122) the formation constants of cobalt were determined. The acid dissociation constants of 2-hydroxymethylnaphth- $[1,2]$-imidazole and 2-hydroxymethylnaphth-[2,3]-imidazole and the stability constants of the divalent element chelates of these compounds have been studied. (123) The acid dissociation constants of 4-hydroxybenzothiazole and the formation constants of its chelates with $\mathrm{Co}$ (II), Mn(II), $\mathrm{Cu}(\mathrm{II}), \mathrm{Zn}(\mathrm{II}), \mathrm{Cd}(\mathrm{II}), \mathrm{Pb}(\mathrm{II})$, and $\mathrm{Mg}(\mathrm{II})$ have also been studied. (124) 
The order of increasing stability of the metal chelates $\mathrm{Cu}>\mathrm{Pb}$, Ni, Co $>\mathrm{Zn}>\mathrm{Cd}>\mathrm{Mn}>\mathrm{Mg}$ is similar to the stability sequence generally obtained for divalent metals.

Cobalt can be separated from nickel by extracting the nickel dimethylglyoxime into chloroform. (100,125) If the extraction is made in an alkaline solution, the extraction of cobalt can be retarded if the cobalt chelate is formed as $\mathrm{Co}\left(\mathrm{NH}_{3}\right)_{6}^{+3}$. (100) Cobalt (as well as $\mathrm{Zn}, \mathrm{Cu}, \mathrm{Mn}, \mathrm{Tl}$ and $\mathrm{Al}$ ) will not, but $\mathrm{NI}$ and $\mathrm{Fe}^{+2}$ will, form chloroform extractable complexes with dimethylglyoxime in the presence of pyridine. (126) Similar separations of cobalt from nickel are possible if the $\mathrm{N} 1$ complexes of cyclohexanedionedioxime $e^{(127)}$ and furildioxime $(128,129)$ are extracted into either chloroform, o-dichlorobenzene, ethyl ether or ethyl acetate.

$\mathrm{Co}^{+3}$ in an acid medium will form an extractable complex with $\alpha$-nitroso$\beta$-naphthol. (130,131) The cobalt complex of $\alpha$-nitroso- $\beta$-naphthol can be extracted from a phosphorlc acid-sodium citrate solution with chloroform. (132) The red 2-nitroso-1-naphthol complex of cobalt can be extracted into either benzene ${ }^{(133)}$ or isoamyl acetate. (134) Cobalt also forms chloroformextractable complexes with isonitrosoacetophenone $\left(\mathrm{C}_{6} \mathrm{H}_{5} \mathrm{COCH}=\mathrm{NOH}\right)$. (135) In this system, cobalt will extract from an acid solution but nickel will not.

Cobalt (as well as $\mathrm{Fe}, \mathrm{Cu}, \mathrm{Ni}, \mathrm{Cr}$, and other metals) can be separated from palladium by extracting the $\alpha$-nitroso- $\beta$-naphthol palladium complex, in the presence of EDTA, into benzene or toluene. (136)

Cobalt cupferrate can be extracted from a dilute acetic acid solution with ethyl acetate or ether. (137)

Cobalt (and $\mathrm{Cu}, \mathrm{Pb}, \mathrm{Hg}, \mathrm{Mn}, \mathrm{U}^{+6}$ and $\mathrm{Zn}$ ) will not react with $\mathrm{N}$-benzoylphenylhydroxylamine in an acid solution having a pH of 4 ; $(138,139)$ however, water insoluble complexes of $\mathrm{Sn}, \mathrm{TI}, \mathrm{Zr}, \mathrm{V}^{+5}, \mathrm{Mo}^{+6}$, and $\mathrm{W}^{+6}$ are formed under these conditions and will extract.

The abllity of $\mathrm{Ni}^{+2}$ to form a complex with 3-hydroxyl-1,3-diphenyltriazine in the $\mathrm{pH}$ range of 4.4-7.0 suggests that a separation from cobalt is possible. (140) The $\mathrm{N1}^{+2}$ complex is soluble in benzene and in chioroform. Cobalt (as well as $\mathrm{Ni}, \mathrm{Bi}, \mathrm{Cd}, \mathrm{Cu}, \mathrm{Pd}, \mathrm{Pt}, \mathrm{Sn}^{+2}, \mathrm{U}^{+6}, \mathrm{Fe}^{+2}, \mathrm{Hg}$, $\mathrm{Th}$, 
Pb, $\mathrm{Zn}, \mathrm{La}, \mathrm{Ce}^{+4}, \mathrm{In}, \mathrm{Sc}$ and $\mathrm{Eu}$ ) forms a complex with 1-(2-pyridylazo)2-naphthol that is insoluble in water. (141) However, it is soluble in both amyl alcohol and carbon tetrachloride.

Sandell(142) reports that cobalt dithizonates can be extracted from solutions at $\mathrm{pH} 7$ to 9 with $\mathrm{CCl}_{4}$ or $\mathrm{CHCl}_{3}$; nickel extracts only from a weakly basic solution. For example, in the analysis of biological samples, Co has been separated from $\mathrm{Fe}, \mathrm{Te}, \mathrm{Cr}, \mathrm{V}$ and other metals that do not form dithizonates by extracting a basic solution ( $\mathrm{pH} 8$ ) with chloroform. (143,144) The organic solution of the dithizionate is quite stable to dilute mineral acids.

Lacoste, et al. ${ }^{(145)}$ report that cobalt reacts with sodium diethyldithiocarbamate and can be extracted with chloroform from solutions having a $\mathrm{pH}$ of 6-8. $\mathrm{Ni}$ and $\mathrm{Fe}^{+3}$ also extract under these conditions.

Cobalt xanthate can be extracted from an anmoniacal solution with ether. $(146,147) \quad \mathrm{N}$ and Fe xanthates are only extractable with chloroform from a weakly acid to neutral solution. (147)

2-mercaptobenzothlazole forms water-insoluble salts of Co (and $\mathrm{B1}, \mathrm{Cd}$, $\mathrm{Cu}, \mathrm{Au}, \mathrm{Pb}, \mathrm{Hg}, \mathrm{N1}, \mathrm{Tl}$, and $\mathrm{Zn}$ ) that are extractable into alcohol or ether. (148)

Cobalt forms a chloroform-extractable complex with thiosalicylideneethylenedilmine. (149) This complex and the $\mathrm{TI}^{+1}, \mathrm{Br}, \mathrm{Cu}, \mathrm{Ag}, \mathrm{Hg}, \mathrm{Pd}^{+2}$ complexes are stable in $\mathrm{HCl}$ or ammonla. The $\mathrm{N} 1, \mathrm{In}, \mathrm{Te}^{+4}, \mathrm{Sn}^{+2}, \mathrm{Sb}^{+3}, \mathrm{Cd}, \mathrm{Pb}, \mathrm{Au}^{+3}, \mathrm{Pt}^{+2}$, $\mathrm{Pt}^{+4}$ complexes are stable in HCl but not in ammonia. The $\mathrm{Zn}$ complex is unstable In both $\mathrm{BC} 1$ and ammonia. The $\mathrm{Al}, \mathrm{Fe}^{+2}, \mathrm{Fe}^{+3}, \mathrm{Mn}$ and $\mathrm{Ga}$ complexes do not react in elther system.

The cobalt-phenylthiourea complex w1ll not extract from dilute BCl solutions Into elther ethyl or amyl acetate. (150) $\mathrm{Nl}, \mathrm{Cr}^{+6}, \mathrm{Fe}^{+3}, \mathrm{Au}^{+3}, \mathrm{Os}^{+4}$, $\mathrm{Pu}^{+3}, \mathrm{Rh}^{+3}$ and $\mathrm{Ir}^{+4}$ behave in a similar manner. $\mathrm{Pd}^{+2}$ is quantitatively extracted while $\mathrm{Pt}^{+4}$ and $\mathrm{Cu}$ are only partially extracted.

$\mathrm{Co}$ (as well as $\mathrm{N}, \mathrm{Cr}, \mathrm{Zn}, \mathrm{AB}^{+3}, \mathrm{Sn}^{+4}$ and $\mathrm{Hg}$ ) can be separated from $\mathrm{Sb}$ and $\mathrm{B} 1$ by forming the ant1pyrine (phenazone) complexes of $\mathrm{Sb}$ and $\mathrm{B} 1$ and extracting them into chloroform. (151) 


\section{Separations by Chromatography}

a. W1th Inorganic Absorbents

The separation mechanisms of metal cations from aqueous solutions upon inorganlc absorbents, such as alumina and clays, have been reviewed by Sacconi, (152) Zechmelster, (153) Smith, ${ }^{(154)}$ and Pollard and Mcomie. (155) with regard to the separation of $\mathrm{Co}^{+2}$ from other metal cations by use of alumina columns, Schwab, et al.,(156) Saccont, $(152,157-160)$ Venture110, (161) and Tanaka and Shibato $(162,163)$ have described this work. Sacconi $(152)$ has also shown that the complex fons of cobalt, the cobaltamines, can be separated on alumina. Cobaltous-tartaric actd and cobaltous-dioxan complexes and their separation from other metal cation complexes have also been studied by the use of alumina columns. $(163,164)$ Erametsa (165) reports that cobaltous-dithizone complexes can be absorbed from $\mathrm{CCl}_{4}$ upon alumina and has proposed a method of separating these complexes from other metal dithizone complexes. Boch ${ }^{(166)}$ has shown that $\mathrm{Co}^{+2}$ and other metal dithizonates absorbed on an alumina column could be eluted with acetone. Tanaka, et al. $(167,168)$ also used a similar system to detect as little as 0.001 parts per million of Co. Paulais ${ }^{(169)}$ has separated cobalt $\alpha$-nitroso$\beta$-naphtholates from those of $\mathrm{Fe}^{+3}, \mathrm{N1}^{+2}$ and $\mathrm{Cu}^{+2}$ by use of a chloroform solution on alumina. Berkhout and Jorgen $(170)$ also used this method to determine cobalt In cast Iron, steels and N1-base alloys; King, et al. (I71) have used it to determine trace cobalt in animal feeds.

When metal 1on solutions contalning cobalt are complexed with nitroso-Rsalt $(172)$ and then passed through an alumina chromatographic ion exchange colum, a separation of cobalt from copper, chromium, nickel and 1ron is effected. The elution of the cobalt complex may be measured colorimetrically. This technique has been applied to metal alloys without prior separation of any of the components.

The use of $\mathrm{AI}(\mathrm{OH})_{3}$ as an absorbent has been investigated by Fricke and Schmah. (173) They have been able to separate cobalt from fron and copper by thls method. Flood ${ }^{(174)}$ has studied the glyclne complexes of $\mathrm{Cu}, \mathrm{N} 1$ and $\mathrm{Co}$ on $\mathrm{Al}_{2} \mathrm{O}_{3}$-1npregnated paper and found that 1t was possible to separate cobalt by varying the glycine concentration. Zolotavia ${ }^{(175)}$ and Vanyarkho and 
Garan1na $(176)$ have used $\mathrm{Al}(\mathrm{OH})_{3}$-1mpregnated paper to separate $\mathrm{Co}^{+2}$ from other metal cations.

Cobalt has been separated from copper by 1norganic chromatography using clays, such as kaolinite, bentonite, and montmorillonite, as the absorbent. (177) When a column is developed with water, $\mathrm{Cu}^{+2}$ is strongly absorbed on the column while cobalt flows rapidly down the column as a pink band. Silica gel has also been used as an absorbent and Milone and Cetini $(178)$ carried out extensive studies on the separation of $\mathrm{Co}^{+2}$ from the other transition elements by use of th1s absorbent system. $\mathrm{Sen}^{(179,180)}$ has used asbestos and $\mathrm{CaSO}_{4}$ as media for the separation of Co from other elements. S1lica gel Impregnated w1th sodium silicate has also been used to separate $\mathrm{Co}^{+2}$ from other elements. (181)

Cobalt and copper diethyldithlocarbamates ${ }^{(182)}$ can be separated from each other on an activated silica column. After the chromatographlc separation, the dithiocarbamates were converted to the corresponding complexes and determined photometrically .

b. With Organic Absorbents (Other than resins and paper)

Powdered 8-hydroxyquinoline has been used as an inert support for aqueous solutions in the separation of $\mathrm{Co}^{+2}$ from other cations and anions. (183) Robinson $(184,185)$ has a so used 8-hydroxyquinoline columns to study the separation of cobalt from other cations contained in aqueous solutions of copper alloys and alloy steels. $\mathrm{Co}^{+2}$ elutes as a red-yellow band under these conditions and some interferences from the various components that gave yellow-colored bands ( such as $\mathrm{WO}_{4}^{+2}, \mathrm{Ag}^{+2}, \mathrm{BI}^{+3}, \mathrm{MOO}_{4}^{+2}, \mathrm{Zn}^{+2}$, and $\mathrm{UO}_{2}^{+2}$ ) were observed.

Cobalt has been separated from mixtures containing $\mathrm{Fe}^{+3}, \mathrm{Cu}^{+2}$, and $\mathrm{Ni}^{+2}$ by use of columns of 8-hydroxyquinoline, naphthaquinoline and cupferron mixed with potato starch. (186) Dimethylglyoxime, dimethylglyoxime-calclum carbonate, and dimethylglyoxime-magnes 1 um carbonate columns have been used to separate nickel and cobalt (187) In another study, Labruto and d'Alcontres ${ }^{(188)}$ have shown that complex cyantdes can be absorbed upon activated charcoal. $\mathrm{K}_{3} \mathrm{Co}\left(\mathrm{NO}_{2}\right)_{6}$, $\mathrm{K}_{4} \mathrm{Fe}(\mathrm{CN})_{6}$, and $\mathrm{K}_{2} \mathrm{Hg}(\mathrm{CN})_{4}$ are completely absorbed; whereas, about $99 \%$ of the $\mathrm{K}_{3} \mathrm{Cu}(\mathrm{CN})_{4}$ and $97 \%$ of the $\mathrm{K}_{2} \mathrm{Cd}(\mathrm{CN})_{4}$ are absorbed. The cobalt complex was easily separated from these other cyanide specles by an elution method. 
Since pectin and pectic ac1d(189) disperse or dissolve in water, they undergo ion exchange in aqueous systems as polyelectrolytes rather than as Ion exchange material in the accepted sense. DiGeacoma and Respol1, (190) using alcohollc solutions, have shown that pectin columns could be used to separate cobalt 1ons from cupric 1ons. Gels, containing such salts as sodium arsenite, borax and sodium silicate, bave been used to separate co from mercury and lead. $(191,192)$ cobalt (and nickel) as complex amines (193) can be ldentifled and determined by the formation of colored ring products on agar gel. Cobalt forms a yellow-brown ring wth nucleonic acid while nickel forms a blue ring.

\section{c. With Ion Exchange Resins}

Kennedy and Davis (194) have shown that the anion exchange resin, Deacldite $H$, and organlc solvents (such as acetone and dimethylformamide) can be used to separate mixtures of cobalt, lithium, and copper (as chlorides) and nickel (as nitrate). The anion adsorption by the basic form of the tertlary amine resin takes place through complex formation with the resin fundamental groups and both the cationic and anionic specles are adsorbed upon the resin in equivalent proportions. When the crosslinking of Deacidite $\mathrm{H}$ is greater than $2 \%$, a sharp reduction in the adsorption of cobalt chloride 16 noted. Adsorption of these specles is also influenced by the nature of the solvent; 1t is much greater from acetone than from dimethyl formamide.

Kraus and others (195-199) have studied the behavior of anions on strongly bas1c exchangers of the polystyrene-divinylbenzene type where the adsorption and elution of the element is defined in terms of molar hydrochloric acid. With respect to the separation of cobalt, the elution constants of $\mathrm{Co}^{+2}, \mathrm{N1}^{+2}$, $\mathrm{Mn}^{+2}, \mathrm{Cu}^{+2}, \mathrm{Fe}^{+2}$, and $\mathrm{Zn}^{+2}$ were studled using a Dowex-1 column and various $\mathrm{HCl}$ concentrations. Cobalt has an adsorption maximum at Intermediate hydrochloric acid concentrations and will elute from the column with hydrochloric acid concentrations of $4.5 \mathrm{M}$ or less. Atteberry, et al. (200) used a strong base anion exchanger and $\mathrm{HCl}$ of varylng concentrations as the eluant to completely separate $\mathrm{Co}^{+2}$ from $\mathrm{Mn}^{+2}, \mathrm{Fe}^{+2}, \mathrm{N1}^{+2}, \mathrm{Cu}^{+2}, \mathrm{Zn}^{+2}, \mathrm{Cd}^{+2}, \mathrm{Ag}^{+1}$, and $\mathrm{Sb}^{+2}$. Blasius and Newger $(201)$ have shown that $\mathrm{Co}^{+2}$ could be adsorbed upon e1ther Permutit ES or 
Dowex-2 resin at $80^{\circ} \mathrm{C}$ and easily separated from $\mathrm{Fe}^{+3}, \mathrm{Mn}^{+2}, \mathrm{Al}^{+3}$, and $\mathrm{NI}^{+2}$. After each of these species were removed with varylng concentrations of HCl, the $\mathrm{Co}^{+2}$ was removed from the column with water. H1cks, et al. (202) have also shown a similar behavior for $\mathrm{Co}^{+2}$ on Dowex-2 resin and 1ts separation from many other elements by elutions with varying concentrations of HCl. Moore and Kraus (199) used Dowex-1 and $9 \underline{M} \mathrm{HCl}$ as the eluant to separate $\mathrm{Co}^{+3}$ (and $\mathrm{Fe}^{+3}$ ) from such elements as $\mathrm{AI}^{+3}$ and $\mathrm{Cu}^{+3}$.

Herber and Irvine ${ }^{(203)}$ have used elutions with varying concentrations of $\mathrm{ABr}$ (no greater than $7 \underline{\mathrm{M}}$ ) from a Dowex-l column to separate radioact1ve $\mathrm{Co}^{60}$ in carrler-free and macro amounts from 1rradiated $\mathrm{Cu}, \mathrm{Zn}$, Ga, and $\mathbb{N}_{1}$. The elutions were Identical with those for $\mathrm{BCl}$.

Neutron-1rradiated blological ash has been analyzed for radiaactive cobalt by an anion exchange resin system $(204)$ and radioactive cobalt in environmental materlals has been separated from radioactlve ruthenlum, zirconium, nioblum, neptunium, cobalt, 1ron zinc, strontium, rare earths, chromium, and cesium by use of $8 \%$ cross-1Inked Dowex-2 (200-400 mesh) resins columns. (205) In each separation, varying concentrations of BCl were used as the eluants. Samsanl (206) used short anion exchange resin (Dowex-2, 200-400 mesh) columos coupled in serles and saturated with chlorlde, c1trate, and hydroxide lons to separate radioactive elements present as impurities in a water cooled nuclear reactor. Molybdenum and tungsten were quantitatively retained on the chloride form; other elements pass through to the cltrate resin, where 1ron, cobalt, zinc, and nickel are adsorbed as complex fons. Manganese and chromium pass through and are finally prec1pitated on the hydroxide form.

Anfon exchange in nitrate solutions is similar, in many respects, to that In chloride solutions. Nelson and Kraus (207) have shown that the non-adsorbable group in nitric acid includes most of the elements which are non-adsorbable in hydrochloric acid. However, the nitrate complexes of the divalent transition elements, 1.e., $\operatorname{Co}(I I), C u(I I)$, and $\mathrm{Zn}(\mathrm{II})$, are less stable than the corresponding chloride complexes.

Cobalt has been separated from solutions of soft magnetic alloys, (208) stainless steel $(209)$ and other ferrous materlals $(210,211)$ by use of an anion exchange resin. After the separation, the cobalt was determined by an EDTA 
titration. Zelgler and Rittner ${ }^{(212)}$ report that the cobalt(II) cyanate complex can be adsorbed by the Ion exchanger, Dowex-1 ( $8 \%$ crossilnkage). Separations of cobalt are possible for cobalt-nickel ratios of 1 to 50 . The cobalt was determined in the eluate by photometry.

Amberlite IRA-400 resin and HCI as an eluant have been used to separate Co (and $\mathrm{Mo}$ and $\mathrm{Ag}$ ) from $\mathrm{TcO}_{4}--(213)$ Dowex-50 columns and 1 M NaCl and $3 \mathrm{M} \mathrm{NaCl}$ eluants have been used to separate the cls and trans isomers of dinltrotetrammine cobalt (III). (214)

Cobalt, but not nickel, 1a strongly adsorbed on ANEX-L resin(215) from greater than $9 \underline{M} \mathrm{HCl}$ solutions, and 1 may be eluted from the resin with water. $\mathrm{Fe}, \mathrm{Cu}, \mathrm{Pb}, \mathrm{Zn}, \mathrm{Cd}$, and $\mathrm{Sn}$ do not separate from cobalt under these conditions.

Metal cations can be convenlently separated into groups by elution from an $8 \%$ crossilnked Dowex-50 (100-200 mesh) resin column with ethylenediammonium perchlorate solution. (216) $\mathrm{Co}^{+2}$ can be eluted from the column w1th a $0.1 \mathrm{M}$ solution of the eluant.

Cobalt can be separated from cadmium (217) by eluting the cadmium from the mixture adsorbed on an $8 \%$ crosslinked $A G-50$ resin column with $0.5 \underline{N}$ HCl. Cobalt is retained on the resin.

\section{d. With Chelating Ion Exchange Resing}

To Increase the selectivity of Ion exchange resins toward closely related cations, resins have been prepared which incorporate chelating compounds into the resin structure. (218) The equilibrium adsorption of several divalent cations over the pH range 1 to 10 has been measured for these resins and, for comparison, for two commerical cation exchangers. The chelating resins showed a capacity comparable to that of the commerclal resins, and, in general, superior selectivity for metal 1ons. For example, the 8-quinolinol resin was very effective in separating cobalt from copper.

e. W1th Paper and S1milar Materials

$\mathrm{Co}^{+2}$ has been separated from other Inorganic lons by use of paper chromatographic techniques and such solvents as water ${ }^{(219)}$, butanol-HCNs, (220) ethermineral ac1ds, (221) alcohollc KCN, (222) tetrahydrofuran-HCl, (223) butanolHCl, $(224,225)$ and nicotine. (226) some of the reagents that have been used to detect cobalt in the presence of other cations on a paper chromatogram include 
$\mathrm{B}_{25},(227)$ organic chelating compounds, $(224,228)$ quercetin, (229) phenylth1osem1carbazide ${ }^{(230)}$ and benzidine.(231) Daylight and ultraviolet light have been used to observe these reactions. (224,232) Alcoholic solutions of dimethylglyoxime have also been used as a reagent in paper chromatography to determine cobaltous 1ons. (233)

Pollard, et al. (234) have studfed the behavior of $\mathrm{Co}^{+2}$ and other cations on paper chromatograms by use of complex-forming mixtures (such as acetylacetone, pyrldine, and acetoncet1c ester), butanol-HNO ${ }_{3}$, butanolacet1c ac1d, and water as solvents. Lederer (235) and DeCarvalho(236) have studied the separation of many of the cations, including $\mathrm{Co}^{+2}$, using alcohol-HCl mixtures as solvents. Walker and Lederer ${ }^{(237)}$ have studied cationic separations of cobalt with binary alcohols mixtures and $\mathrm{BCl}$ as solvents. Ketone-HCI, (238) butanol- $\mathrm{HBr},(239)$ alcohol- $\mathrm{HNO}_{3}(240)$ mixtures and other organlc $11 q u 1 d s(239)$ bave also been used as solvents in simflar studies.

Lederer and Lederer ${ }^{(24 I)}$ report that a mixture of methyl n-propylketoneacetone and $\mathrm{HCl}$ can be used as a solvent to separate cobalt from 1ron, nIckel, and manganese on a paper chromatogram. Sh1bota and Uemura (242) used acetoneHCl as a solvent for the same separation. Similar studies have been made by Alran, (243) Alran and Barnabas (244) and Twear1. (245) In all Instances, rubeanic acid was used as the reagent for detecting the cobalt on the chromatogram.

Several ketonic solvent mixtures (such as acetone-water-HCl) have been used for the separation of cobalt from nlckel, manganese, copper, iron, titanium, vanadium and urantum. (246) cobalt (as well as $\mathrm{Fe}^{+3}$ and $\mathrm{N1}^{+2}$ ) has been separated from aluminum, (247) from nickel, (248) from copper, (249) and from 1ron, t1tanium, aluminum, vanadium and nlckel $(250)$ by paper chromatography. Lacourt $(251)$ also has reviewed the general applications of paper chromatography to the separation of cobalt from other metals and 1ts subsequent determination by other analysis techniques.

Paper chromatography has also been used to separate and 1dentify rad10active $\mathrm{CO}^{60}(5.27 \mathrm{y})$ in an $\mathrm{Fe}^{59}(45 \mathrm{~d})$ solution. (252) $\mathrm{CO}^{60}$ as a carrier-free tracer kas been separated from an 1rradiated manganese target by use of 
paper chromatography and acetone-HCl as the solvent. (253)

Burstall, et al. (254) have used cellulose chromatographic columns composed of wood pulp, cotton linters, or fllter paper to separate and determlae cobalt, nickel and copper in steel. Methylpropylketone, and methylpropylketone - acetone-water-BCl mixtures were used as solvents. A cellulose column has also been used by Anderson and Lederer (255) to quant1tatively separate $\mathrm{Co}$ (and $\mathrm{N} 1, \mathrm{Cu}$ and $\mathrm{Fe}$ ) from thallium. Butanol-1 $\mathrm{N} \mathrm{HCl}$ was used as the solvent.

Filter paper columns 1mpregnated with 8-hydroxyquinoline also have been used to separate cobalt from other metals. (256) D1oxan, pyridine, chloroform, acetone, methanol, propanol, and butanol were used as the solvents in this work.

Cobalt (as well as copper and nickel) amine and ethylenediamine complexes (257) can be separated from each other by paper chromatography (258) by eluting with solvents composed of mixtures of ether, methanol, water and concentrated hydrochloric ac1d. A good separation of copper from cobalt and nickel was achleved. The behavior of $s 1 x \operatorname{co}($ III) complexes (259) was also studied using butanol-HCl, butanol-ammonia, butanol-acet1c acid, acetone, HCI and water as solvents for the paper chromatographic separat1on. Cobalt complex behavior on paper chromotographic columns has also been investigated using $\mathrm{NH}_{2} \mathrm{Cl}$ solutions at varying concentrations. (260)

We1dman (261) reports on the use of paper chromatography to separate nickel from cobalt. A sharp separation was obtalned by using n-tributylphosphate in hydrochloric ac1d-methanol (in the ratio of $2: 1$ ) as the solvent.

Singh and Dey (262) have investigated the separation of $C o(I I)$ from $\mathrm{Cd}(\mathrm{II}), \mathrm{Cu}(\mathrm{II})$ and $\mathrm{Ni}(\mathrm{II})$ by use of paper str1p chromatography and using aqueous ethanol as the solvent. No sat1sfactory separation of $N I$ (II) and Cd(II) from $C o($ II) was possible due to the spreading and overlapping of zones.

Frierson, et al. (263) used a two solvent system composed of butyl alcohol In concentrated $\mathrm{HCl}$ and 3-methyl-2-butanone In acetone and $\mathrm{BCl}$ to separate cobalt, nlckel, copper and zinc lons by paper chromatography.

Berg and Strasser (264) used cyclohexane, methanol and dioxan as sol- 
vents to separate cobalt(III), copper(II) and nickei(II) acetylacetone chelates by paper chromatography.

Majumdar and Singh $(265)$ report on the use of a electro-chromatographic techn1que for the separation of cobalt, z1nc, manganese, and nickel in the preeence of a number of electrolytes. Separation sequences of Mn-Co-N1, $\mathrm{N1}$ Co-Mn, $\mathrm{Zn}-\mathrm{Co}-\mathrm{Mn}$, and $\mathrm{Mn}-\mathrm{Co}-\mathrm{Zn}$ were observed. In this work, a quarternary separation using potassium cyanide solution at a pH of 6.0 gave the sequence, N1- $\mathrm{Zn}-\mathrm{Co}-\mathrm{Mn}$. A slight spreading of the zinc band into that of the cobalt occurred for these conditions.

\section{DISSOLUTION OF SAMPLES CONTAINING RADIOACTIVE COBALT}

Most materials contalning radioactive cobalt 1sotopes can be dissolved In a manner similar to that used for non-active sample materials containing cobalt. H1llebrand, et al. (266) report that cobalt minerals and ores, metals and alloys, etc., can be broken up and/or dissolved by a preliminary attack with hydrochloric ac1d, followed by the addition of nitric acid. Any insoluble residue resulting from this processing can be fused with potassium pyrosulfate and sodium carbonate. Some ores, such as those contalning silver, can be best attacked by the use of nitric and sulfuric acid mixtures. In extreme cases, fusion with sodium peroxide can be employed. Blologlcal materials are best dissolved by wet-ash1ng, 1.e., digestion with $\mathrm{H}_{2} \mathrm{SO}_{4}-\mathrm{HClO}_{4}-\mathrm{HNO}_{3}$ mIxtures while being heated. (267) Gorsuch(268) also reports on wet or dry oxidation techniques for determining cobalt and other trace elements in organic and blological materials.

Any one of these methods of sample dissolution can be adapted for use in the radiochemistry of the cobalt radionuclides. However, it is considered most practical to add the inactive cobalt carrier (if an isotopic carrier. method is being followed) to the mixture before dissolution begins. This should assist in achleving an exchange of the cobalt carrier with the desired cobalt radionuclide.

\section{SAFETY PRACTICES}

No matter what method is used to decompose a sample, adequate safety precautions should be followed. The toxicology of most elemental compounds 
have been reported by Pleters and Creyghton $(269)$ and It should be consulted for Information on handing cobalt-containing materials safely.

Safety practices in handling radioactive sample materials are alway important in radiochemistry. The discharge of radioactivity by explosion, evolution, spliling, etc., Into a laboratory area can be hazardous and can result in widespread contamination. Thus, some source of information on safehandling practices in processing radioactive samples should be consulted before a radiochemical analysis for the cobalt radionuclides is undertaken. One such source is that wh1ch is given in the Oak Ridge National Laboratory's Master Analytical Manual. (270) Many other simflar sources of information exist and should be consulted.

\section{COUNTING TECHNIQUES FOR THE RADIOACTIVE COBALT ISOTOPES}

The analysis of sample materials containing the cobalt radionuclides may be completed either by a direct (nondestructive) measurement of the radioactivity of the particular cobalt radionuclide in the radioactive sample or by obtaining the radionuclide in some suitable form following a radiochemical processing of the radioactive sample. The use of either technique is dependent upon the cobalt radionuclide being measured and the sample material being analyzed. The radionuclide's half-life, the type of radiations it emits as it decays, and the energy of its radiations, as well as the radioactivity induced into the other elements in the sample matrix, must be considered in selecting the method to be followed.

Table I of this monograph shows the nuclear characteristics of each of the known radioactive isotopes of cobelt. The chief radionuclides of cobalt usually encountered by the radiochemist are $\mathrm{Co}^{60 \mathrm{~m}}(10.5 \mathrm{~m}), \mathrm{Co}^{58}$ $(72 \mathrm{~d})$, and $\mathrm{Co}^{60}(5.27 \mathrm{y})$. These isotopes are produced as a result either of a nuclear particle reaction on the stable isotope of cobalt $\left(\mathrm{Co}^{59}\right)$ or on the stable isotopes of other elements. The radioactivity of any of these cobalt radionuclides can be analyzed and measured by standard GeigerMueller, gama scintillation and proportional counting technique. (271-274)

The nondestructive analysis technique has been used most frequently in determining the cobalt radionuclides in neutron-irradiated materials usually being analyzed by a radioactivation analysis method. $(275,276)$ 
For example, Schonken ${ }^{(277)}$ has reported on the use of a nondestructive gamma spectrometry method to detect and determine the $\mathrm{Co}^{60}(5.27 \mathrm{y})$ radioactivity (and subsequently the stable $\mathrm{Co}^{59}$ content) in neutron-irradiated biological materials. Bate and Leddicotte ${ }^{(278)}$ have used a nondestructive gamma spectrometer method employing the complement-subtaction technique to determine cobalt (as $\mathrm{Co}^{60}, 5.27 \mathrm{y}$ ) and nickel (as $\mathrm{Co}^{58}, 72 \mathrm{~d}$ ) in such materials as soils, vegetation, water, and metals and alloys. Salmon (279) has also measured the $\mathrm{Co}^{60}$ content (and hence the Co ${ }^{59}$ content) of stainless steel by a neutron radioactivation method involving nondestructive gamma spectrometry. In another gamma spectrometer method, Leddicotte and Guss $(280)$ have determined the cobalt content of Inconel by a nondestructive measurement of the $\mathrm{Co}^{60}$ radioactivity. In this same investigation, it was also possible to measure the $c_{0}^{58}(72 \mathrm{~d})$ radioactivity produced as the result of the $n, p$ reaction upon $\mathrm{Ni}^{58}$ with good precision and accuracy in order to determine the neutron flux of the reactor facility used for the irradiation. In similar neutron flux measurements, the $\mathrm{Co}^{60}$ and $\mathrm{Co}^{58}$ induced in neutron threshold detectors have also been measured by a nondestructive technique. (281)

Bmery $(282)$ has determined the cobalt content in alloys and animal tissue by a nondestructive gama-spectrometer measurement of the co $60 \mathrm{~m}$ $(10.5 \mathrm{~m})$ radionuclide. Westermark and Fineman ${ }^{(283)}$ have also used a similar technique to determine the $\mathrm{Co}^{59}$ content of stainless steel.

The radiochemical separation methods reported in Section VII of this monograph have most frequently been concerned with the assay of radioactive $\mathrm{Co}^{60}$. However, it should be noted that Kaiser and Meirike ${ }^{(284)}$ have used the $c^{60 \mathrm{~m}}$ radionuclide following a rapid radiochemical separation to determine cobalt in animal tissues. Likewise, Mullins, et al., (284) have measured the radionctivity of $\mathrm{Co}^{58}$ in order to determine stable nickel in a variety of sample materials by a neutron radioactivation analysis method involving radiochemical separations similar to those described by Leddicotte $(286,287)$ and reported as Procedures 17 and 18 in Section VII. 
VII. COLIECTION OF DETAIIED RADIOCHEMICAL PROCEDURES FOR THE COBAIT RADIONUCLIDES

The detalled radiochemical procedures presented in this section have evolved from each investigator's choice of ideas and techniques similar to those expressed in section III of this monogranh. Cartier-free and carrier methods are considered only in this presentation. However, the $\mathrm{Co}^{60}$ tracer-isotope dilution techniques, reported by such investigators as Salyer and Sweet ${ }^{(87-89)}$ and Eristavi, et al., (287) could be considered by other investigators in their work with the cobalt radionuclides.

Only a few applications of carrier-free separations for the cobalt radionuclides have been noted in the literature. (252,253,298, 305) Typical of these procedures are those presented herein as Procedures 19 and 22. However, it should be posstble to use any of the ideas and techniques from the solvent extraction or chromatography investigations cited in this monograph to serve as a means of obtaining carrier-free cobalt radionuclides.

Most of the carrier radiochemical procedures have been originated either for use in the preparation of radioactive cobalt tracers $(204,288)$ (see Procedures 1-10), the separation of $c_{0}^{60}$ from fission products $(62,205,289)$ (see Procedures 11-13), or in the use of radioactivation analysis. $(275,276)$ In particular, in radioactivation analysis, carrier radiochemical methods have been used in analyses concerned with the determination of microgram and submicrogram amounts of cobalt in biological materials, $(204,284,290-296)$ metals and alloys, $(60,296,299-305)$ meteorites, $(306-308)$ rocks and minerals, $(307,309,310)$ and marine sediments. $(307,311)$ Procedures 14 to 24 are typical of the separation methods used in these investigations. Similar procedures have been used by Hall, (291) Tobias, et al., (292) Benson, (293) Dele, (294) Koch, et al., (295) Albert, et al., (300) Riezler, (301) Talbot, et al., (302) and Cornand and Gillis ${ }^{(304)}$ in their use of radioactivation analysis to determine trace cobalt in such sample materials as tissues and metals and alloys. Procedures 15 and 16 described herein are unique in that they use radioactive $C_{0}^{60}$ carriers. The reports by Westermark and Fineman $(283)$ and by Kalser and Meinke ${ }^{(284)}$ should be consulted for additional information on this application. 
In each of the radiochemical procedures that follow, special information regarding the procedure's use, the type of nuclear bombardment, the type of materlal analyzed, separation time, etc., appears as part of each procedure. Whenever possible, an evaluation of each procedure is made with regard to its usefulness in the decontamination of other radioactive species from the radioactive cobalt isotopes.

PROCEDURE I

Procedure Used In: Preperation of radionctive cobalt tracers

Method: Ion exchange

Element Separated: $\operatorname{co}^{60}(5.27 \mathrm{y})$

Type of Material Analyzed: Neutron 1rradiated targets and cobalt targets for cyclotron production of radiolron $(204)$

Type of Nuclear Bombardment: Neutron and deuteron

Procedure By: Helwig, et al (204) (Adapted from studies by Kraus and others $(\overline{195-199)})$

Chemical Y1eld of Carrier: Quant1tetive

Time of Separation: Short

Degree of Purif1cation: Excellent from $\mathrm{Fe}^{59}$

Equlpment Requ1red: Ion exchange columas

Procedure:

1. To a solution of the target materlal, add cobalt and/or 1ron carrier. Evaporate to dryness. Dissolve residue $\ln 5 \underline{\mathrm{MCl}}$ and transfer the solution to the resin column (Note 1 ).

2. Elute the cobalt from the resin column with a $20-\mathrm{ml}$ volume of $5 \mathrm{M} H \mathrm{HCl}$. Collect the effluent in a sultable contalner (Note 2).

3. Evaporate the cobalt effluent to a small volume and mount for counting (Note 3).

Notes:

1. Dowex-1, 200-400 mesh, resin packed in a pyrex glass column, having a cross section of $1.13 \mathrm{~cm}^{2}$ and a bed $13 \mathrm{~cm}$ long. Column conditloned with $5 \underline{\mathrm{MCl}}$. 
2. Further elution of the column with a volume of $0.5 \mathrm{M}$ HCl removed $\mathrm{Fe}^{59}$.

3. The $C 0^{60}$ ganma radioactivity was determined by counting liquid samples in 1 dram vials with a sodium iodide crystal counter.

\section{PROCEDURE 2}

Procedure Used In: Preparation of radiactive cobalt tracers

Method: Solvent extraction and precipitation

Type of Mater1al Bombarded: N1ckel (as separated 1sotopes)

Type of Nuclear Bombardment: a. $37^{\prime \prime}$ cyclotron (protons)

b. 60" cyclotron (protons and deuterons)

Procedure by: L1lly (Reported by Melnke(288))

Separation Time: 10 minutes

Chemical Y1eld of Carrier: 90\%

Decontamination: Factor of 5

Equipment Required: Standard

\section{Procedure}

1. Dissolve $\mathrm{N} 1$ foll, welghing $3-5 \mathrm{mg}$, in a $10 \mathrm{ml}$ beaker containing $0.5 \mathrm{ml}$ of hot $6 \mathrm{~N} \mathrm{HNO}_{3}$. Take to dryness on preheated hot plate.

2. Add 3-4 drops of hot conc. HCl and take to dryness. Repeat.

3. Add $2 \mathrm{mg}$ Co as the chlorlde sol'n and warm slightly. Transfer to a $50 \mathrm{ml}$ separatory funnel and dilute to $10 \mathrm{ml}$ with $\mathrm{H}_{2} \mathrm{O}$.

4. Add $5 \mathrm{gms}$ of solid $\mathrm{NH}_{4} \mathrm{SCN}$ and shake until all of the crystals are dissolved. Extract co from this sol'n by shaking with an equal volume of ethyl ether-amyl alcohol ( $1: 1)$.

5. Draw off the $\mathrm{H}_{2} \mathrm{O}$ layer from this extraction and discard 1 .

6. Add $10 \mathrm{ml}$ of $6 \mathrm{~N} \mathrm{NH}_{4} \mathrm{OH}$ to the organic layer in the separatory funnel to destroy the complex and reextract the co.

7. Draw off the ammoniacsl layer into a small beaker, heat to boiling, and ppt $\mathrm{COS}$ by adding $\mathrm{NH}_{4} \mathrm{HS}$ sol'n. Prepare this ppt for counting as desired. 
PROCEDURE 3

Procedure Used In: Preparation of radioactive cobalt tracers

Method: Precipitation

Type of Material Bombarded: Copper or Nickel

Type of Nuclear Bombardment: 184" cyclotron (neutrons, deuterons)

Procedure by: Lilly (Reported by Melnke(288))

Separation Time: 4 hours

Chemical Y1eld of Carrier: $\sim 90 \%$

Decontamination: $10^{2}$

Equipment Required: Standard

\section{Procedure}

A. Cobalt Prom Cu(10 gms ) + neutrons - 184"

1. Dissolve $\mathrm{Cu}$ target in $50-100 \mathrm{ml}$ of hot $6 \mathrm{~N} \mathrm{HCl}$ containfing $5 \mathrm{ml}$ of $30 \% \mathrm{~B}_{2} \mathrm{O}_{2}$. Boll off excess $\mathrm{H}_{2} \mathrm{O}_{2}$ and add $25-50 \mathrm{mg}$ Co and $5 \mathrm{mg}$ $\mathrm{N} 1$ as the chloride sol'ns. Dilute the sample to $\sim 1$ liter and add $\mathrm{NH}_{4} \mathrm{OH}$ until the sol'n is neutral or very slightly acidic.

B. Cobalt from N1 (1-2 gms) + deuterons - 184"

1. Dissolve $\mathrm{N} 1$ target in the least possible volume of conc. $\mathrm{HNO}_{3}$. Convert nitrates to chlorides by adding successive portions of conc. HCl and taking to a low volume. Add $25-50 \mathrm{mg}$ Co and $75 \mathrm{mg}$ Cu as the chloride sol'ns. Dilute the sample to $\sim 500 \mathrm{ml}$ and add $\mathrm{NH}_{4}$ OH unt1l the sol'n is neutral or very slightly acidic.

In each of the above cases, cont1nue as follows:

2. Add conc. $\mathrm{NH}_{4} \mathrm{HSO}_{3} \mathrm{Sol} \mathrm{n} ., 1 \mathrm{ml}$ at a time, until all of the $\mathrm{Cu}$ is reduced (as shown by the lack of any localized blue color when a few drops of conc. $\mathrm{NH}_{4} \mathrm{OH}$ are added). Add solld $\mathrm{NH}_{4} \mathrm{SCN}$ dissolved In a small amount of $\mathrm{H}_{2} \mathrm{O}$ until ppt'n is complete.

(3) Coagulate the CuSCN ppt by heating and filter it through a double thickness of 42 Whatman paper in a large glass funnel. Discard the ppt.

(4) Boil the filtrate to expel $\mathrm{SO}_{2}$ and then add $3 \mathrm{ml}$ of conc. $\mathrm{HCl}$ per $100 \mathrm{ml}$ of volume.

(5) Add a freshly prepared hot sol'n of alpha-nitroso-beta- 
naphthol, made by dissolving $10 \mathrm{gms}$ of the salt in $100 \mathrm{ml}$ of $50 \%$ acetic acid, as long as a ppt is produced.

(6) Filter the ppt through retentive paper. Wash it well with warm $6 \mathrm{~N} \mathrm{HCl}$, and then with warm $\mathrm{H}_{2} \mathrm{O}$ until free from acid. Ignite the ppt until all of the paper is burned off.

(7) Dissolve the $\mathrm{CoO}$ in $\mathrm{HCl}$ and add $100 \mathrm{mg} \mathrm{Cu}$ and $25 \mathrm{mg} \mathrm{Ni}$ as the chloride sol'ns. Adjust the acidity as in step (1) and repeat steps (2) through (6) above.

(8) Convert this $\mathrm{CoO}$ to $\mathrm{CoCl}_{2}$ by treating it with anhydrous $\mathrm{Cl}_{2}$ at $650^{\circ} \mathrm{C}$ for 30 minutes.

(If desired, part of the CoO in step (7) may be dissolved in $\mathrm{HCl}$ and the cobalt fraction purifled still further by adding $\mathrm{Cu}$ and $\mathrm{Ni}$ hold-back carriers and repeating the procedure.)

Remarks :

The above procedure was designed for preparing a sample for analysis in the calutron. In case a small spectrograph is to be used, the amount and final form of the Co may need changing.

\section{PROCEDURE 4}

Procedure Used In: Preparation of radioact1ve cobalt tracers

Method: Precipitation

Type of Materlal Bombarded: Copper

Type of Nuclear Bombardment: $60^{\prime \prime}$ cyclotron (37 Mev alphas, $9.5 \mathrm{Mev}$ protons, $19 \mathrm{Mev}$ deuterons) 184 " cyclotron ( $388 \mathrm{Mev}$ alphas, $348 \mathrm{Mev}$ protons, 194 Mev deuterons)

Procedure by: Batzel (Reported by Melnke ${ }^{(288)}$ )

Separation Time: 40 minutes

Chemlcal Y1eld of Carrier: 30-40\%

Decontamination: $\sim 10^{2}$

Equipment Required: Standard 
PROCEDURE 4 (Continued)

Procedure

1. Dissolve copper in minimum amount of concentrated $\mathrm{HNO}_{3}$, and boll to dryness or with $\mathrm{HCl}$ to destroy $\mathrm{HNO}_{3}$. Add $5 \mathrm{mg}$ of Co carrier and 1-2 mg of the neighboring elements to serve as holdback.

2. Remove copper as sulf1de from a $1 \mathrm{~N}$ HCl solution. Wash the prec1p1tate with 1 N $\mathrm{HCl}$ saturated with $\mathrm{H}_{2} \mathrm{~S}$.

3. Bo1l supernate to remove $\mathrm{H}_{2} \mathrm{~S}$ and neutralize with KOH. Make 2-3 $\underline{\mathbf{N}}$ In acetic ac1d. Saturate about $5 \mathrm{cc}$ of water with $\mathrm{KNO}_{2}$ and add $0.3 \mathrm{cc}$ of acetic ac1d. Heat and add to the hot solution of cobalt.

4. Allow to settle for 5 minutes in a steam bath. Cool, and centrifuge. Wash with a $5 \% \mathrm{KNO}_{2}$ solution ac1difled with acetic acld.

5. Dissolve the ppt in concentrated $\mathrm{HCl}$; add $1 \mathrm{mg}$ each of holdback carrlers and repreclpltate.

6. Weight as the potassium cobaltinitrite.

\section{PROCEDURE 5}

Type of Material Bombarded: Uranium netal foil

Type of Nuclear Bombardment: 184" cyclotron (full energy particles;

high energy fission)

Procedure by: Folfer (Reported by Meinke ${ }^{(288)}$ )

Separation Time: 2.5 hours

Chemical Yield of Carrier: $\sim 50 \%$

Decontamination: From $10^{4}$ to $10^{8}$

Equipment Required: Standard

\section{Procedure}

(1) Uranium target is dissolved in cone. HCl (plus a small amt. conc. $\mathrm{INO}_{3}$ to clear up the sol'n) or in conc. $\mathrm{HNO}_{3}$ (should be $>10 \pi$ ). Use $\sim 1 / 4$ (or more) of target sol'n for aliquot. idd 10-20 me Co carrier and make basic with $\mathrm{nH}_{3}$. 
(2) Centrifuge and wash ppt twice with sat'd aqueous $\mathrm{NH}_{3}$. Combine supernatant and washings.

(3) Scavenge twice with $\mathrm{Fe}(\mathrm{OH})_{3}$, twice with $\mathrm{BaCO}_{3}$ is $\mathrm{SrCO}_{3}$ (add sat'd $\mathrm{Na}_{2} \mathrm{CO}_{3}$ and check $\mathrm{pH}$ to be sure sol'n is basic enough, $\sim \mathrm{pH} 10)$.

(4) Make $0.7-0.8 \underline{\mathrm{N}}$ in HCl. Scavenge with CuS, CdS, $\mathrm{Pe}_{2} \mathrm{~S}_{7}$ (for Tc) HgS, $\mathrm{PdS}_{2}$ (1-2 mg of carriers).

(5) Make basic with $\mathrm{NH}_{3}$ and ppt $\mathrm{CoS}$ with $\mathrm{H}_{2} \mathrm{~S}$. Wash to remove all $\mathrm{NH}_{4}{ }^{+}$. Dissolve in 1 ce conc. $\mathrm{HNO}_{3}$. Dilute to $\sim 4 \underline{\mathrm{N}} \mathrm{HNO}_{3}$ and scavenge $:$ th $1-2 \mathrm{mg} \mathrm{AgCl}$ twice.

(6) Make basic with $\mathrm{KOH}$ to ppt $\mathrm{Co}(\mathrm{OH})_{2}$ (upon heating goes to $\left.\mathrm{Co}(\mathrm{OH})_{3}\right)$. Centr. and wash. Dissolve ppt in 3 cc $2-3 \underline{N}$ Hac. Add $2 \mathrm{mg} N \mathrm{~N}$ holdback and heat.

(7) Add 3-4 cc 6 N HAc sat'd with $\mathrm{KNO}_{2}$ hot (Caution! Beware of foaming over). Digest $10 \mathrm{~min}$ hot. Chill in ice bath to retard bubbles and centrifuge $\mathrm{K}_{3} \mathrm{Co}\left(\mathrm{NO}_{2}\right)_{6} \cdot \mathrm{I} 1 / 2 \mathrm{H}_{2} \mathrm{O}$ (yellow).

(8) Wash, and dissolve in conc. HCl (with heating - green sol'n is obtained).

(9) Repeat steps (3) through (8). Then repeat (6) and (7).

(10) Wash twice with $\mathrm{H}_{2} \mathrm{O}$, EtOH, $\mathrm{Et}_{2} \mathrm{O}$. Filter, dry at $110^{\circ} \mathrm{C}$ for $5 \mathrm{~min}$. Weigh as $\mathrm{K}_{3} \mathrm{Co}\left(\mathrm{NO}_{2}\right)_{6} \cdot \mathrm{H}_{2} \mathrm{O}$.

Remarks :

(1) In step (6), the $\mathrm{Co}(\mathrm{OH})_{2}$ ppt becomes grey-brom on heating in the water bath. This does not interfere with the procedure.

(2) For additional information, see Scott, "Standard Methods of Chemical Analysis," D. Van Nostrand Co., Inc., New York, Ed. 5 Vol. I, pp 305-14. 
PROCEDURE 6

Procedure Used In: Preparation of radloactive cobalt tracers

Method: Precipitation and solvent extraction

Type of Mater1al Bombarded: Copper or N1ckel

Type of Nuclear Bombardment: a. $60^{\text {n }}$ cyclotron (neutrons)

b. 184" cyclotron (deuterons)

Procedure By: Lilly (Reported by Melnke(288) )

Separation T1me: 1 hour

Chemlcal Yleld of Carrier: $\sim 90 \%$

Decontamination: $10^{2}$

Equipment Required: Standard

Procedure:

A. Cobalt from N1 (separated 1sotopes) $+p, a, n-60^{n}$

1. D1ssolve $\mathrm{N1}$ fo11, welghing $3-5 \mathrm{mg} \cdot$, in a few drops of cone. HNO 3 and boll off $\mathrm{ENO}_{3}$ with successive portions of HCl. Add $2 \mathrm{mg} \mathrm{Co}, 2 \mathrm{mg} \mathrm{Fe}$ and $5 \mathrm{mg}$ $\mathrm{Cu}$ as the chloride sol'ns.

2. D1lute to $50 \mathrm{ml}$ with $\mathrm{H}_{2} \mathrm{O}$ and heat to bolling. Ppt $\mathrm{Fe}(\mathrm{OH})_{3}$ by adding $\mathrm{NH}_{4} \mathrm{OH}$ in excess and coagulate the ppt well by heating. Filter the $\mathrm{Fe}(\mathrm{OH})_{3} \mathrm{ppt}$ through No. 42 Whatman paper in a glass funnel and wash with a small amount of 1\% $\mathrm{NH}_{4} \mathrm{Cl}$ sol'n. Make the filtrate slightly acldic with $\mathrm{HCl}$. Add conc. $\mathrm{NH}_{4} \mathrm{HSO}_{3}$ sol'n dropwise unt1l all of the $\mathrm{Cu}$ is reduced (as shown by the lack of any locallzed blue color when a few drops of conc. $\mathrm{NE}_{4} \mathrm{OH}$ are added). Add solld $\mathrm{NH}_{4} \mathrm{SCN}$ dissolved in a small amount of $\mathrm{H}_{2} \mathrm{O}$ unt1l ppt'n is complete.

3. Coagulate the CuSCN ppt by heating and filter it through a double thickness of No. 42 Whatman paper in a glass funnel. D1scard the ppt. Bo1l the flltrate to a volume of $10 \mathrm{ml}$ to expel $\mathrm{SO}_{2}$ and transfer to a $50 \mathrm{ml}$ separatory funnel.

\section{B. Cobalt from Cu $(50-100 \mathrm{mg})+\mathrm{d}-184^{\prime \prime}$}

1. Dissolve $\mathrm{Cu}$ target in conc. HCl containing a few arops of conc $\mathrm{HNO}_{3}$. Boll off the excess $\mathrm{HNO}_{3}$. Add $2 \mathrm{mg} \mathrm{Co}, 2 \mathrm{mg} \mathrm{Fe}$, and $2 \mathrm{mg} \mathrm{N1}$ as the chloride sol'ns.

2. Dilute to $50 \mathrm{ml}$ with $\mathrm{H}_{2} \mathrm{O}$ and heat to bolling. Ppt $\mathrm{Fe}(\mathrm{OH})_{3}$ by adding $\mathrm{NH}_{4}$ OH in excess and coagulate the ppt well by heating. Filter the Fe(OH) 3 ppt 
through No. 42 Whatman paper in a glass funnel and wash with a small amount of $1 \% \mathrm{NH}_{4} \mathrm{Cl}$ sol'n. Make the filtrate slightly acldic with $\mathrm{HCl}$. Add cone. $\mathrm{NH}_{4} \mathrm{HSO}_{3}$ sol'n dropwise until all of the $\mathrm{Cu}$ is reduced (as shown by the lack of any locallzed blue color when a few drops of conc. $\mathrm{NH}_{4} \mathrm{OH}$ are added). Add solld $\mathrm{NH}_{4} \mathrm{SCN}$ dissolved in a small amount of $\mathrm{H}_{2} \mathrm{O}$ unt1l ppt'n is complete.

3. Coagulate the CuSCN ppt by heating and filter 1t through a double th1ckness of No. 42 Whatman paper in a glass funnel. Discard the ppt. Bo1l the filtrate to a volume of $10 \mathrm{ml}$ to expel $\mathrm{SO}_{2}$ and transfer to a $50 \mathrm{ml}$ separatory funnel.

\section{Cobalt from $\mathrm{Cu}(0.1-0.5 \mathrm{gms})+\mathrm{n}-184^{\mathrm{n}}$}

1. Dissolve $\mathrm{Cu}$ target in $10 \mathrm{ml}$ of hot $6 \mathbb{\mathrm { N } \mathrm { HNO }} 3$ in a 6 mall beaker and boll off $\mathrm{HNO}_{3}$ with successive portions of $\mathrm{BCl}$. Add $2 \mathrm{mg} \mathrm{C} \circ$ and $2 \mathrm{mg} \mathrm{N} 1$ as the chloride sol'ns.

2. Add $\mathrm{H}_{2} \mathrm{O}$ and $\mathrm{HCl}$ so as to give a volume of $25-30 \mathrm{ml}$ with $0.3 \underline{\mathrm{N}}-0.5 \underline{\mathrm{N}}$ $\mathrm{HCl}$. Heat to boiling and pass in $\mathrm{H}_{2} \mathrm{~S}$ to ppt CuS. Coagulate the ppt by heating and filter 1t through a small fine sintered glass filter. Wash the ppt with a small amount of $\mathrm{H}_{2} \mathrm{O}$ and discard $1 \mathrm{t}$.

3. Bo1l the filtrate to a volume of $\sim 10 \mathrm{ml}$ and then transfer 1 to a $50 \mathrm{ml}$ separatory funnel.

In all three of the above cases continue as follows:

4. Add 5 gms of solld $\mathrm{NH}_{4} \mathrm{SCN}$ and shake until all of the crystals are dissolved. Extract Co from this sol'n by shaking with an equal volume of ethyl ether-amyl alcohol (1:1).

5. Draw off the $\mathrm{H}_{2} \mathrm{O}$ layer from this extraction and discard 1 .

6. Add $10 \mathrm{ml}$ of $6 \mathrm{~N} \mathrm{NH}_{4} \mathrm{OH}$ to the organic layer in the separatory funnel to destroy the complex and reextract the Co.

7. Draw off this amonlacal layer into another $50 \mathrm{ml}$ separatory funnel and make 1t slightly acldic with HCl. Add $2 \mathrm{mg} \mathrm{N} 1$ as the chloride sol'n and repeat the extraction as in step (4) above.

8. Draw off the $\mathrm{H}_{2} \mathrm{O}$ layer and discard 1 t. Treat the organic layer with $\mathrm{NH}_{4} \mathrm{OH}$ as described in step (6) above. 
9. Draw off the ammonlacal layer 1nto a $50 \mathrm{ml}$ beaker, boll to a volume of $5 \mathrm{ml}$, and ppt CoS by adding $\mathrm{NH}_{4}$ HS sol'n. Prepare th1s ppt for counting as des1red.

\section{PROCEDURE 7}

Procedure Used In: Preparation of radioactlve cobalt tracers

Method: Preclpitation and solvent extraction

Type of Material Bombarded: Arsen1c

Type of Nuclear Bombardment: 190 Mev deuterons

Procedure By: Hopkins (Reported by Melnke ${ }^{(288)}$ )

Separation T1me: 1 hour

Chemlcal Yleld of Carrier: $~ 70 \%$

Decontamination: $\sim 10^{2}$

Equipment Required: Standard

\section{Procedure:}

1. Dissolve As in minimum $\mathrm{HNO}_{3}+\mathrm{H}_{2} \mathrm{O}_{2}$, add $2 \mathrm{mg}$ Se and Ge carrier, $5 \mathrm{mg} \mathrm{Co}$.

2. Make alkaline with $\mathrm{NE}_{4} \mathrm{OH}$, pass in $\mathrm{H}_{2} \mathrm{~S}$ rapldly for 1 mlnute only. Centrifuge immediately.

3. Dissolve in minimum conc. $\mathrm{HCl}$, add I mg $\mathrm{Cu}$, ppt Cus from hot I N $\mathrm{BCl}$.

4. Add other carriers, evaporate to small volume, make $6 \mathrm{~N} \mathrm{HCl}$, extract 4 times w1th equal volume ethyl ether.

5. Evaporate to near dryness, add $\mathrm{H}_{2} \mathrm{O}$ to $2 \mathrm{ml}$ volume, and an equal volume of solid KSCN. Extract 4 times with $2 \mathrm{ml}$ amyl alcohol.

6. Extract out of amyl alcohol with $4 \mathrm{ml} 1 \mathrm{~N} \mathrm{KOH}$.

7. D1ssolve in $\mathrm{BCl}$ and reppt hydroxide with KOH.

8. Dissolve in minlmum acet1c acld, dilute to $4 \mathrm{ml}$, saturate with $\mathrm{KCl}$, and add $\mathrm{KNO}_{2}$ unt1l pptn of $\mathrm{K}_{3} \mathrm{Co}\left(\mathrm{NO}_{2}\right)_{6}$ is complete. 


\section{PROCEDURE 8}

Procedure Used In: Preparation of radloactive cobalt tracers

Method: Electrodeposition

Type of Mater1al Bombarded: Copper

Type of Nuclear Bombardment: $60^{\prime \prime}$ cyclotron (19 Mev deuterons)

$184^{n}$ cyclotron (194 Mev deuterons)

Procedure by: Stewart and Softky (Reported by Meinke (288),

Separation Time: $4-6$ hours

Chem1cal Y1eld of Carrier: 90-100\%

Decontamination: $\quad 10^{5}$

Equipment Requ1red: Sta1nless steel strip electrodes, electrolys1s cell, platinum discs, and stirrers, 2 ampere d.c. rectifler unit.

\section{Procedure:}

1. Dissolve $\mathrm{Cu}$ foll in minimum dilute $\mathrm{HNO}_{3}$. Add $1 \mathrm{mg}$. $\mathrm{Co}, \mathrm{N} 1$, and Mn carriers as nitrates, and 2 drops conc. $\mathrm{H}_{2} \mathrm{SO}_{4}$. D1lute to about $20 \mathrm{ml}$ with dist1led water.

2. Electrodepos1t copper on stalnless steel strip cathode set into beaker in which the foll was dissolved, using a rotating Pt spiral anode at $2-3$ volts, $1-2$ amperes.

3. When solution 1 s water whlte, remove the electrodes, add I ml conc. $\mathrm{H}_{2} \mathrm{SO}_{4}$ and evaporate to $\mathrm{SO}_{3}$ fumes to remove $\mathrm{HNO}_{3}$.

4. Dilute to $35-50 \mathrm{ml}$ and saturate with $\mathrm{H}_{2 \mathrm{~S}}$ to preclpitate residual $\mathrm{Cu}$. F1lter. Boll filtrate to expel $\mathrm{H}_{2} \mathrm{~S}$, add $2 \mathrm{mg} \mathrm{Cu}$ carrier as chlorlde and repeat.

5. Boll filtrate 5 minutes to expel $\mathrm{H}_{2} \mathrm{~S}$, make solution slightiy amonical, then add 1-2 ml 1\% dimethylglyoxime in ethanol to ppt MiDMG. F1Iter. Wash ppt with hot water.

6. Ac1d1fy f1ltrate w1th $\mathrm{HNO}_{3}$ and evaporate to. $\mathrm{SO}_{3}$ fumes to destroy alcohol. Add a few drops of conc. HCl and again take to $\mathrm{SO}_{3}$ fumes to insure removal of $\mathrm{NO}_{3}{ }^{-}$.

7. Transfer solution to a $30 \mathrm{ml}$ tower electrolysis cell fltted with a $1^{\pi} \mathrm{Pt}$ disc cathode, make strongly ammonical, and electrolyze at 1-2 amperes for about 30 minutes, using a slowly rotating Pt anode. Cobalt deposits as a smooth adherent plate on the cathode. $\mathrm{MnO}_{2}$ deposits at the same time on the anode. 
8. When Co is completely deposited, replace the electrolyte with distilled water while the current is st1li on. Remove the anode quickly to prevent sol'n of the $\mathrm{MnO}_{2}$, pour off the water, and rinse the cobalt plate with alcohol.

Remarks:

(In step (5) if solution is too strongly ammonical at this point, NiDMG will be incompletely precipitated.)

(In step (7) $\mathrm{NH}_{4} \mathrm{OH}$ should be added periodically during the electrodeposition. Current should be kept lower than 2 amperes to give a smooth adherent plate.)

\section{PROCEDURE 9}

Procedure Used In: Preparation of radoactive cobalt tracers

Method: Precipitation

Type of Materlal Bombarded: Copper foll

Type of Nuclear Bombardment: a. 60" cyclotron (deuterons)

b. $184^{n}$ cyclotron (deuterons)

Procedure By: Stewart-Softky (Reported by Me1nke(288),

Separation Time: I hour

Chemical Yleld of Carrier: $\sim 80 \%$

Decontamination: $10^{6}$

Equipment Required: Standard

Procedure:

1. D1ssolve copper in minimum dilute $\mathrm{HCl}+$ a few drops of $30 \% \mathrm{H}_{2} \mathrm{O}_{2}$. Boll off peroxide. Add $2 \mathrm{mg} F e$ and Co carriers as chloride.

2. Preclpitate $\mathrm{Fe}(\mathrm{OH})_{3}$ with excess $\mathrm{NH}_{4} \mathrm{OH}$. Filter and wash with $\mathrm{NH}_{4} \mathrm{OH}$ (allute).

3. Acidxfy filtrate to about $0.1 \mathrm{~N} \mathrm{HCl}$, add a few drops of $\mathrm{NH}_{4} \mathrm{HSO}_{3}$ to reduce $\mathrm{Cu}^{+2}$ to $\mathrm{Cu}^{+}$(decolorized solution) and warm to near bo1ling. Add $\mathrm{NH}_{4} \mathrm{SCN}$ crystals until no further precipitation of CuSCN takes place. Let 
settle for 15 minutes. Filter through No. 42 filter paper. Wash prec1pitate with a $1 \%$ solution of $\mathrm{NH}_{4} \mathrm{SCN}$.

4. Add sufficient conc. HCl to filtrate to make about $1 \mathbb{N}$ acld and heat to near bolling. Add 5-10 ml of a freshly prepared solution of a-nitrosoB-naphthol reagent. ( $10 \mathrm{~g} \alpha$-n1troso- $\beta$-naphthol in $100 \mathrm{ml} 50 \%$ acetic ac1d.) Let stand 30 minutes to insure complete precipitation of cobalt.

\section{PROCEDURE 10}

Procedure Used In: Preparation of radioactive cobalt tracers Method: Solvent extraction and precipitation

Type of Materlal Bombarded: Copper foll

Type of Nuclear Bombardment: a. $60^{\text {n }}$ cyclotron (deuterons)

$$
\text { b. 184" cyclotron (deuterons) }
$$

Procedure By: Stewart-Softky (Reported by Meinke (288)

Separation Time: 1 hour

Chemical Yield of Carrier: 80-100\%

Decontamination: $10^{5}$

Equipment Required: Standard

Procedure:

1. Dissolve copper foil in $6 \underline{\mathrm{N}} \mathrm{HCl}$ and a few drops of $30 \% \mathrm{H}_{2} \mathrm{O}_{2}$. Bo1l of the peroxide. Add $2 \mathrm{mg} F e, \mathrm{Zn}$, and Co carrier as chlorides.

2. Preclpitate $\mathrm{Fe}(\mathrm{OH})_{3}$ with excess $\mathrm{NH}_{4} \mathrm{OH}$, centrifuge and pour off supernatant. Dissolve preclpitate in $\mathrm{HCl}$ and repeat. Add 2nd supernatant to the original.

3. Make solution about $0.1 \mathrm{~N}$ with $\mathrm{ECl}$. Add a few drops of $\mathrm{NH}_{4} \mathrm{HSO}_{3}$ to reduce $\mathrm{Cu}^{+2}$ to $\mathrm{Cu}^{+1}$ (shown by decolorized or pale yellow solution). Warm to near bolling. Add $\mathrm{NH}_{4} \mathrm{SCN}$ crystals until no further precipitation of CuSCN takes place. Let settle for 15 minutes. F1lter through whatman No. 42 filter paper directly into a separatory funnel. Wash prec1p1tate with a $1 \%$ solution of $\mathrm{NH}_{4} \mathrm{SCN}$ containing a little $\mathrm{NH}_{4} \mathrm{HSO}_{3}$. 
4. Add $58 \mathrm{NH}_{4} \mathrm{SCn}$ to the solution in the separatory funnel and extract $\left(\mathrm{NH}_{4}\right)_{2} \mathrm{Co}(\mathrm{SCN})_{4}$ with a $1: 1$ amyl alcohol-dlethyl ether solut1on. Add 2 ml conc. $\mathrm{BC} 1$ and $I \mathrm{~g} \mathrm{NH} 4 \mathrm{SCN}$ and repeat extraction unt1l solvent layer 1s colorless (2-3 extractions are usually sufficlent). Re-extract cobalt from the combined solvent layers w1th $6 \mathrm{~N} \mathrm{NH}_{4} \mathrm{OH}$.

5. Make solution ac1d ( $\mathrm{pH} \mathrm{2-3)} \mathrm{w1th} \mathrm{HCl}$ and add an additional $1 \mathrm{mg}$ of $\mathrm{Zn}$ as $\mathrm{ZnCl}_{2}$. Saturate w1th $\mathrm{H}_{2} \mathrm{~S}$ to preclpitate $\mathrm{ZnS}$, centrifuge and decant supernatant into another cone. Make slightly ammoniacal and warm to coagulate cos precipitate.

\section{Remarks:}

It was found that $\mathrm{Zn}$ extracted partially from the saturated thiocyanate solution with the alcohol-ether mixture.

\section{TROCEDURE 11}

Procedure Used In: Separation of cobalt radloact1v1ty from radloctlve corrosion products (mixed with fused salts of uranium)

Method: Prec1p1tation

Radionuclide Separated: $C^{60}(5.27 \mathrm{y})$

Types of Materlals Bombarded: Inconel and fused salts (62)

Type of Nuclear Bombardment: Neutron

Procedure By: Smith, R. R., et al (62)

Separation Time: Short

Chemlcal Y1eld of Carrier: $~ 70 \%$

Decontamination: Good from 1ron, chromium, and f1ssion products

Equipment Required: Standard

\section{Procedure:}

1. Add $2 \mathrm{ml}$ standard1zed co carrier $(2.00 \mathrm{mg} / \mathrm{mi})$ to fused salt solution (Tote 1). Add $\mathrm{NH}_{4} \mathrm{OH}$ unt1l $\mathrm{Al}(\mathrm{OH})_{3}$ prec1pitates. Centr1fuge; transfer supernate to new centrifuge tube. 
2. Dissolve precipitate in a minimum quantity of conc. $\mathrm{HNO}_{3}$. Neutralize with $\mathrm{NH}_{4} \mathrm{OH}$ and add excess $\mathrm{NH}_{4} \mathrm{OH}$. Centrifuge; combine supernate with Initial supernate.

3. Dissolve $\mathrm{Co}\left(\mathrm{NH}_{4}\right)^{++}$complex by adding sufficlent glacial acetic ac1d. Then add excess $3 \mathrm{M}$ HAc. D1lute to $25 \mathrm{ml}$ with water.

4. Add $6 \mathrm{ml}$ of $3 \underline{\mathrm{M}} \mathrm{HAc}$ saturated with $\mathrm{KNO}_{2}$ to the solution. D1gest 10 minutes In an Ice bath. Centrifuge; discard supernate. Wash the preclpitate tw1ce w1th $30 \mathrm{ml}$ of water. D1scard washes.

5. Dissolve prec1pitate in several ml of conc. HCl. Boll off decompos1tion products. Add $\mathrm{Cs}$ and $\mathrm{Ba}$ carrlers and dilute to $25 \mathrm{ml}$ with water.

6. Prec1pltate cobalt hydroxide with $10 \mathrm{ml}$ of saturated KOH solution. Wash precipitate with water. Centrifuge; discard wash liquid.

7. Dissolve cobalt hydroxide precipitate in $3 \mathrm{ml}$ of 6 M BAc. Add $\mathrm{Zr}$ and $\mathrm{Cr}$ holdback carrlers. Dilute and add $3 \mathrm{M}$ HAc saturated with $\mathrm{KNO}_{2} \cdot \mathrm{K}_{3} \mathrm{CO}\left(\mathrm{NO}_{2}\right)_{6}$ precipitates.

8. Centrifuge. Wash twlce with water and twice with absolute ethanol. Welgh after drylng. Mount, compute carrier yleld, and count (Note 2).

Notes:

1. Aluminum nitrate solution is used to dissolve the fused salt.

2. Gamma pulse analysis used to measure $c 0^{60}$ radianctivity. 
Procedure Used In: Separation of radioact1ve cobalt from f1ssion products

Method: Ion exchange

Element Separated: $c^{60}(5.27 \mathrm{y})$

Type of Mater1al Analyzed: Natural materlals (waters, so1ls, vegetation) (205)

Type of Nuclear Bombardment: Neutron reaction products

Procedure By: Bon1, A. I. (205)

Chem1cal Yield of Carrier: > $95 \%$

Time of Separation: Several hours

Degree of Puriflcation: $>10^{4}$ from $\mathrm{Fe}^{59}, \mathrm{Zn}^{65}, \mathrm{Cr}^{51}, \mathrm{Cs}^{137}, \mathrm{Sr}^{89}, \mathrm{Ru}^{106}, \mathrm{~Np}^{239}$, $\mathrm{Zr} 95, \mathrm{Nb}^{95}$, and rare earth rad1onuclides.

Equipment Required: Standard

Procedure:

1. Prepare samples in following manner:

a. Water - evaporate to dryness and dissolve residue in $3 \mathrm{~N} H \mathrm{HCl}$ $0.1 \mathrm{~N}$ HF m1xture.

b. Solls (muds) - leach with $3 \mathrm{~N} \mathrm{HCl--0.1} \mathrm{N}$ HF mixture (Note 1).

c. Vegetation - fire in a muffle furnace and then dissolve the ash or leach $1 \mathrm{t}$ with $3 \mathrm{~N} \mathrm{HCl-O.1} \mathrm{N} \mathrm{HF}$ mixture (Note 1 ).

2. To the dissolved or leached sample material, add a known aliquot of $\mathrm{Ru}^{+4}, \mathrm{Cr}^{+3}, \mathrm{Fe}^{+3}, \mathrm{Co}^{+2}, \mathrm{Cs}^{+1}, \mathrm{Ce}^{+3}, \mathrm{Nb}^{+5}, \mathrm{Ba}^{+2}, \mathrm{Sr}^{+2}, \mathrm{Zr}^{+4}$, and $\mathrm{Zn}^{+2}$ carrier solutions to $1 \mathrm{t}$ (Note 2). Then add $1 \mathrm{ml}$ of a 0.2 gram per $\mathrm{ml}$ thloacetam1de solution to the mixture. Digest and allow the precipitate to settle. Repeat the thioacetamide addition. Remove thioacetamide precipltate $\left(\mathrm{Ru}^{+4}\right)$ elther by centrifugation or filtration (Note 3).

3. Evaporate the supernatant liquid (or f1ltrate) to dryness and then add $2 \mathrm{ml}$ of conc. $\mathrm{HNO}_{3}$ and transfer the slurry to a $50-\mathrm{ml}$ centrifuge tube. Add $25 \mathrm{ml}$ of fumlng $\mathrm{HNO}_{3}$ to the tube; cool the solution under cold tap water. Digest the mixture for 15 minutes. Centrifuge and decant'supernatant liquid to new centr1fuge tube (Note 4 ).

4. Evaporate the supernatant 11quid to dryness and then add $5 \mathrm{ml}$ of distilled water to dissolve the residue. Heat, if necessary. Add 5 ml of $0.2 \mathrm{~N} \mathrm{H}_{2} \mathrm{SO}_{4}-0.6 \mathrm{~N} \mathrm{EF}$ mixture to the solution. Digest for 15 minutes; then centrifuge the m1xture and pour the supernatant 11quid directly on to a 
prevlously prepared Dowex-2 resin column (Note 5) washed with $15 \mathrm{ml}$ of a 0.1 $\mathrm{H}_{2} \mathrm{SO}_{4}-0.3 \mathrm{~N} \mathrm{HF}$ solution. Wash the precipitate (Note 6) with $5 \mathrm{ml}$ of the same acld solution, centrifuge the slurry, and add the supernatant directly to the resin column. Allow the liquid to pass through the resin column into a $100 \mathrm{ml}$ beaker.

5. Wash the resin by adding $40 \mathrm{ml}$ of a $0.1 \mathrm{~N}_{2} \mathrm{SO}_{4}-0.3 \mathrm{~N}$ BF solution in 5-ml allquots to the column and comblne the wash effluent with the sample effluent. Cautlously evaporate the comblned effluents to dryness (Note 7).

6. Dissolve the residue in a minimum of conc. HCl. Heat, if necessary. Quantitatively transfer the solution to another prepared Dowex-2 resin column (Note 5) that has been washed with $15 \mathrm{ml}$ of conc. HCl. Allow the solution to pass through the resin column, collecting the effluent in a 50-ml beaker. Wash the resin by the addition of $40 \mathrm{ml}$ of conc. HCl 1 in $5 \mathrm{ml}$ aliquots and combine the effluent with that of the sample (Note 8 ).

7. Continue the resin column elution with $40 \mathrm{mI}$ of $8.5 \mathrm{~N} \mathrm{HCl}-0.5 \mathrm{~N} \mathrm{HF}$ solution. Collect this effluent (Note 9 ).

8. Elute the $\mathrm{Co}^{60}$ from the resin by adding $30 \mathrm{ml}$ of $5 \mathrm{~N} \mathrm{HCl}$. Collect this fraction in a 50-ml beaker (Note 10).

9. Evaporate the cobalt fraction to a small volume. Transfer to a plastic sample vial and count the $c 0^{60}$ radioactivity by a gamma scintillation counter (Note 11).

\section{Notes:}

1. More than $99.0 \%$ of the radionuclides are leached by this process.

2. A total of $20 \mathrm{mg}$ of $\mathrm{Co}^{+2}$ are added; all others range from 1-20 mgs each.

3. The radioactivity of this preclpitate can be assayed.

4. The stront1um nitrate prec1pitate obtalned here can be further processed and the radioactivity of $\mathrm{sr}^{89}$ measured.

5. Ion exchange column: $17 \mathrm{~cm}$ long $\times 0.9 \mathrm{~cm} I$. D., w1th stopcock and 50-ml capac1ty reservior. Resin: $8 \%$ cross-linked Dowex-2 in the chloride form; $200-400$ mesh. 
6. Following wash process, this preclpitate may be processed for rare earth radionuclides.

7. At this point, the resin column is processed for $\mathrm{Zr}-\mathrm{Mb}$ radiosctivity (see Bont $(205)$ ).

8. Th1s fraction contains $\mathrm{Cs}^{137}$ and $\mathrm{Cr}^{51}$.

9. Th1s eraction conta1ns $\mathrm{Np} 239$.

10. The resin column retains $\mathrm{Fe}^{59}$ and $\mathrm{Zn}^{65}$. If required, it can be further processed (see Boni (205)).

11. In this instance, a scintillation well counter, equipped with a 1.75 Inch diameter $x 2$ inch $\mathrm{NaI}(\mathrm{T} 1)$ crystal having a $5 / 8$ inch diameter $x 1.5$ inch central well, was used.

\section{PROCEDURE 13}

Procedure Used In: Decontamination of F1ssion Product Solutions.

Method: Precipltation - solvent extraction - electrodeposition

Radionuclide Separated: $C_{0}^{60}(5.27 \mathrm{y})$

Type of Material Analyzed: F1ssion Product Solutions

Type of Nuclear Bombardment: $\operatorname{co} 59(n, y) \operatorname{co} 60$

Procedure by: Burgus, W.W. (Reported by Klelnberg(289),

Chemical Y1eld of Carrier: $70-75 \%$

Time of Separation: $2-5$ hours

Degree of Puriflcation: Excellent from stable nlckel and from fission product radionuclides.

Equipment Required: a. Standard laboratory plus plating equipment described under "Preparation and Standardization of Carrier" given below.

b. Plat1ng cells: $5 \mathrm{mil}$ Pt square cathode (prewelghed), mounted on brass plate and held in position by $7 / 8^{n}$ ID glass cylinder, with gasket between platinum and glass cylinder; rotating Pt anode; d-c source; resistance in series with current source and cell. (One plating cell each per sample and standard.)

Reagents: Standard, except for

a. Amyl alcohol - ethyl ether mixture: equal parts by volume, and 
b. Cobalt carrier as prepared and stendardized in the procedure.

Procedure:

A. Preparation and Standardization of Carrier

Dissolve 49.3 of $\mathrm{Co}\left(\mathrm{NO}_{3}\right)_{2} \cdot 6 \mathrm{H}_{2} \mathrm{O}$ in $\mathrm{H}_{2} \mathrm{O}$, add $1 \mathrm{ml} \mathrm{HrO}_{3}$, and dilute to 1 liter with $\mathrm{H}_{2} \mathrm{O}$.

P1pet $5.0 \mathrm{ml}$ of the above carrier solution into a 125-ml Erlenmeyer Plask and add $5 \mathrm{ml}$ of $\mathrm{E}_{2} \mathrm{O}$ and $3 \mathrm{ml}$ of conc. $\mathrm{H}_{2} \mathrm{SO}_{4}$. Carefully boll dowa to coplous $\mathrm{SO}_{3}$ fumes to remove $\mathrm{NO}_{3}^{-}$10n. $\mathrm{CoOl}$, dilute to 8 to $10 \mathrm{ml}$ and allow the solution to come to room temperature. Cautiously neutralize with conc. $\mathrm{NH}_{4} \mathrm{OH}$, then add $1 \mathrm{ml}$ In excess and allow to cool to room temperature. Transfer the solution quantitatively to plating cell and dilute to $15 \mathrm{ml}$. Add about 2 gm of solld $\left(\mathrm{NH}_{4}\right)_{2} \mathrm{SO}_{4}$, Introduce rotating anode, and stir unt1l the $\left(\mathrm{NH}_{4}\right)_{2} \mathrm{SO}_{4}$ has dissolved. Plate out co with continual stirring. The current is initially kept at 0.10 amp at about 3 volts. During the flrst $1 / 2$ hour of plating the current is gradually 1ncreased to $0.20 \mathrm{amp}$, whlch current is maintained for the remainder of the plating process. (The optimum plating time 1s at least 3 hours.) The cell is dismantled, the plate removed and washed several times with distilled $\mathrm{H}_{2} \mathrm{O}$ and once with ethanol. It 1 s then alr-drled and welghed.

Four standardizations, with results agreelng within about $0.2 \%$ are usually made.

\section{B. Radlochemlcal Procedure}

1. To the sample in a $40-\mathrm{ml}$ centrifuge tube, add sufficlent $\mathrm{H}_{2} \mathrm{O}$ to bring the volume to $20 \mathrm{ml}$. Add $3 \mathrm{ml}$ of standard Co carrler and $1 \mathrm{ml}$ of $\mathrm{N} 1$ carrler. Prec1pitate CO and $\mathrm{N} 1$ hydroxides by the addition of $10 \mathrm{M}$ KOH (Note 1). Centr1fuge and wash the hydroxides w1th $15 \mathrm{ml}$ of $\mathrm{H}_{2} \mathrm{O}$, discarding the supernate and washings •

2. Dissolve the precipitate by warming with $3 \mathrm{ml}$ of $6 \mathrm{M} \mathrm{HC}_{2} \mathrm{H}_{3} \mathrm{O}_{2}$. Dilute to $25 \mathrm{mI}$ with $\mathrm{H}_{2} \mathrm{O}$ and cool to room temperature.

3. Prec1p1tate $\mathrm{K}_{3} \mathrm{Co}\left(\mathrm{NO}_{2}\right)_{6}$ by addition of reagent made by saturating $6 \mathrm{ml}$ of $3 \mathrm{M} \mathrm{BC}_{2} \mathrm{H}_{3} \mathrm{O}_{2}$ with $\mathrm{KNO}_{2}$. Allow about $3 \mathrm{~min}$ for complete preclpitation. Centri- 
fuge, discard the supernate, wash the prectpltate once with $30 \mathrm{mI}$ of $\mathrm{H}_{2} \mathrm{O}$, and discard the washings.

4. Dissolve the $\mathrm{K}_{3} \mathrm{Co}\left(\mathrm{NO}_{2}\right)_{6}$ by the addition of several milliliters of conc. $\mathrm{HCl}$. Boll off the decomposition products. Add $1 \mathrm{ml}$ of $\mathrm{NI}$ carrier and dilute to $25 \mathrm{ml}$.

5. Precipitate Co and $\mathrm{N} 1$ hydroxides with $10 \mathrm{M} \mathrm{KOH}$ as before (Step I). Dissolve the hydroxides as in Step 2 .

6. Repeat Step 3 .

7. Dissolve the $\mathrm{K}_{3} \mathrm{Co}\left(\mathrm{NO}_{2}\right)_{6}$ in 4 or $5 \mathrm{ml}$ of conc. $\mathrm{HCl}$, bolling down almost to dryness. Add 2 drops of $\mathrm{Pd}$ and 4 drops of $\mathrm{Cu}$ carriers. Dilute to $20 \mathrm{ml}$ and make about $0.1 \mathrm{M}$ in $\mathrm{HCl}$. Heat to boiling and pass in $\mathrm{H}_{2} \mathrm{~S}$ for 5 minutes. Filter onto No. 40 Whatman f1lter paper, catching the filtrate in a 125-ml Erlenmeyer flask and discarding the sulfide scavenging precipltate.

8. Boll out $\mathrm{H}_{2} \mathrm{~S}$ from the filtrate. Add 2 drops $\mathrm{Pd}$ and 4 drops of $\mathrm{Cu}$ carrlers and dilute to $20 \mathrm{ml}$. Make $0.1 \underline{\mathrm{M}}$ In $\mathrm{BCl}$, heat to bo1ling and pass in $\mathrm{H}_{2} \mathrm{~S}$ for $5 \mathrm{~min}$. Again remove sulfides by filtration (Step 7).

9. Bo1l out $\mathrm{H}_{2} \mathrm{~S}$ from f1Itrate. Th1s w1ll require concentration almost to dryness (Note 2). Dilute to $25 \mathrm{ml}$ and transfer quant1tat1vely to 40-ml centrifuge tube. Add 4 drops of $\mathrm{Fe}$ carrier and prec1pitate $\mathrm{Fe}(\mathrm{OH})_{3}$ by addition of conc. $\mathrm{NH}_{4} \mathrm{OH}$, adding about $0.5 \mathrm{ml}$ of $\mathrm{NH}_{4} \mathrm{OH}$ in excess. Centrifuge and discard $\mathrm{Fe}(\mathrm{OH})_{3}$ scavenge, retalning the supernate.

10. Acldify the supernate w1th $\mathrm{HCl}$. Add 4 drops of Fe carrier and remove $\mathrm{Fe}(\mathrm{OH})_{3}$ again by the addition of conc. $\mathrm{NH}_{4} \mathrm{OH}(0.5 \mathrm{ml}$ excess). Centrifuge and discard the precipitate.

11. Repeat Step 10 .

12. Acldify the supernate from 10 with conc. $\mathrm{BCl}$, adding $1 \mathrm{ml}$ in excess. Transfer to $125-\mathrm{ml}$ separatory funnel. Add $15 \mathrm{gm}$ of $\mathrm{NB}_{4} \mathrm{SCN}$ and shake unt1l all the solid has dissolved. Extract the Co-SCN complex into $50 \mathrm{ml}$ of amyl alcoholethyl ether mlxture. Wash the organlc layer twice with $10 \mathrm{ml}$ of $\mathrm{NH}_{4} \mathrm{SCN}$ solution. D1scard washings. 
13. Back-extract the Co into $20 \mathrm{ml}$ of $\mathrm{H}_{2} \mathrm{O}$ to wh1ch 4 to $6 \mathrm{ml}$ of conc. $\mathrm{NH}_{4} \mathrm{OH}$ has been added. DIscard the organic layer and transfer the aqueous layer to a 40-ml centrifuge tube.

14. Precipitate $\operatorname{CoS}$ from solution by passing in $\mathrm{H}_{2} \mathrm{~S}$ for $1 \mathrm{mln}$. Centrifuge and discard the supernate.

15. Transfer the CoS preclpitate with 5 to $10 \mathrm{ml}$ of $\mathrm{H}_{2} \mathrm{O}$ to a $125-\mathrm{ml}$ Erlenmeyer flask. Add $10 \mathrm{ml}$ of conc. $\mathrm{NNO}_{3}$. Boll nearly to dryness ( 1 to $2 \mathrm{ml}$ ). Add $3 \mathrm{ml}$ of conc. $\mathrm{H}_{2} \mathrm{SO}_{4}$ and heat to $\mathrm{SO}_{3}$ fumes. $\mathrm{CoOl}$ and add 5 to $10 \mathrm{ml}$ of $\mathrm{H}_{2} \mathrm{O}$ (slowly). CoOl again. Neutralize with conc. $\mathrm{NH}_{4} \mathrm{OH}$ and add $1 \mathrm{ml}$ in excess. Add 2 gm of $\left(\mathrm{NH}_{4}\right)_{2} \mathrm{SO}_{4}$, transfer to plating cell and electroplate co on a welghed Pt foll. (For a circular foll about $7 / 8^{n}$ diameter begln plating at 3 or 4 volts and $0.10 \mathrm{amp}$. After the flrst $1 / 2$ hour Increase current to 0.20 amp. Plate for 2-1/2 to 3 hours.) After plating, wash with distilled water and then with ethanol. Dry at room temperature, welgh, and count. The counting procedure is dependent on the 1sotope Involved.

Notes:

1. The purpose of the initial precipitation by means of $\mathrm{KOH}$ is to remove the co from the strongly acid solution. For as complete a precipitation of $\mathrm{K}_{3} \mathrm{Co}\left(\mathrm{NO}_{2}\right)_{6}$ as possible, mineral acids and oxidizing agents must be absent.

2. The $\mathrm{H}_{2} \mathrm{O}$ is removed by bolling to prevent precipitation of Co as CaS when the $\mathrm{Fe}(\mathrm{OH})_{3}$ scavenging step is made. 


\section{PROCHDURE 14}

Procedure Used In: Radioactivation analys1s

Method: Ion exchange with carriers

Element Separated: co $^{60}(5.27 \mathrm{y})$

Type of Material Analyzed: Stalnless steel, its corrosion products, and other elements, present as impurities in a watercooled nuclear reactor.(206)

Type of Nuclear Bombardment: $\mathrm{Co}^{59}(\mathrm{n}, \gamma) \mathrm{Co}^{60}$

Procedure By: Samsahl (206)

Chem1cal Yleld of Carrier: Quant1tative

Degree of Puriflcation: Excellent

Equipment Required: Neutron source and standard laboratory equipment

\section{Procedure:}

The information given by Samsahl (206) in the section of his report entitled "Experimental" is considered to be rather concise and informative for use as the detalled Procedure for this radiochemical separation method. It reads as follows:

\section{Experimental}

The experiments were performed w1th 1rradiated (Note 1) metallic chromlum, molybdemum and tungsten and salts of the cations, $\mathrm{Na}^{+1}$, $\mathrm{Mn}^{+2}, \mathrm{Fe}^{+2}, \mathrm{Co}^{+2}, \mathrm{N1}^{+2}, \mathrm{Cu}^{+1}, \mathrm{Zn}^{+2}$, and $\mathrm{Sr}^{+2}$. The samples were individually brought 1nto solution with hot $1: 1$ HCl contalning a few drops or $\mathrm{H}_{2} \mathrm{O}_{2}$ and taken to dryness on a water bath. Subsequently, the res1dues were dissolved in water and diluted to a sultable strength of gamma activity. Carriers were added in amounts of about $5 \mathrm{mg}$ of appropriate cation per $100 \mathrm{ml}$ of solution. No carriers were added to the solutions of tungsten and molybdenum. Then $20 \mathrm{ml}$ portions of a single gamma emitter solution were added to four 1on exchange colurns cons1sting of Dowex-2 (200-400 mesh) resin in the c1trate, chlorlde and hydroxide forms, and Dowex-50 (200-400 mesh) in the hydrogen form. Each column cons1sted of $10 \mathrm{ml}$ of water sedimented resin contalned in a $2.5 \mathrm{~cm}$ diameter glass fllter cruclble (Note 2 ). The active solutions were sucked through at a rate of about $4 \mathrm{mill1-}$ 11ters per minute and the columns washed with two 5-ml portions of 
water and drained by suction. Finally, the cructbles were placed directly at a definite geometry on the top of a gamma scintillation detector and the radioactivity assayed with a single channel pulse analyzer.

The activity of the Dowex-50 resin was measured and used as a standard for the estimation of the percent absorption on the other resins. The eluate was controlled for possible gamma activity.

\section{Notes:}

1. Irradiated in the Swedish R-I reactor. Samples of Irradiated steel and $\mathrm{D}_{2} \mathrm{O}$ were also processed by this method.

2. SamsahI's report ${ }^{(206)}$ should be consulted for a description of the 1on exchange column and other Information.

\section{PROCEDURE 15}

Procedure Used In: Radioactivation Analys1s

Method: Solvent extraction and precipitation

Element Separated: $c_{0}^{60 \mathrm{~m}}(10.5 \mathrm{~m})$

Type of Material Analyzed: Reactor Steel (283)

Type of Nuclear Bombardment: $\mathrm{Co}^{59}(\mathrm{n}, \gamma) \mathrm{Co}^{60 \mathrm{~m}}$

Procedure By: Westermark and Fineman (283)

Chem1cal Y1eld of Carrier: 60-90\% (as a radioactive carrier)

Separation Time: 30 minutes

Decontamination: Good; some interference from $\mathrm{Mn}^{56}$ (2.6 b)

Equipment Required: Neutron source and standard laboratory equipment

\section{Procedure:}

1. D1ssolve the 1rradiated steel turniags (Notes 1 and 2) In 10-15 ml of bolling $7 \underline{\mathrm{M}} \mathrm{HCI}$ and $I \mathrm{ml}$ of radioactive $\mathrm{Co}^{+3}$ carrier solution (Note 3 ). After the sample has been put into solution, cool the solution to room temperature and transfer 1t to a separatory funnel (Note 4 ). 
2. To the separatory funnel, add $\mathrm{l} \mathrm{ml}$ of conc. $\mathrm{BCl}$ and $7.5 \mathrm{ml}$ of ethyl ether. Shake the mlxture and allow the two phases to separate. Discard the organlc phase (Note 5) and collect the aqueous phase in another funnel and then add another volume of ether and shake the mixture.

3. Allow the phases to separate and transfer the aqueous phase to a $200 \mathrm{ml}$ beaker. Bo1l the solution to remove any ether contalned from the aqueous solution and then add hot $40 \mathrm{ml}$ of nitrosonaphthol solution (Note 6).

4. Cool the mixture and then filter through a porcelain filter cruclble. Wash the precipltate with water and mount for a measurement on a gamma scintillation spectrometer (Note 7 ).

5. Determine the amount of stable cobalt in the test sample by comparing the amount of $\mathrm{co}^{60 \mathrm{~m}}(10.5 \mathrm{~m})$ radioact1vity (Note 7 ) measured in $1 \mathrm{t}$ with that found In a comparator, or standard, cobalt sample (Notes 8 and 9). The amount of $\mathrm{Co}^{60}(5.27 \mathrm{y})$ observed becomes a measure of the chemical recovery of the experiment (Notes 3 and 7 ).

\section{Notes:}

1. These 1rradiations were made in the $D_{2} \mathrm{O}$ - moderated reactor, $\mathrm{RI}$, belonging to $A B$ Atomenerg1, Sweden. Neutron flux equal to about $6 \times 10^{11} \mathrm{n} / \mathrm{cm}^{2} / \mathrm{sec}$. Limit of measurement about $5 \mathrm{ppm}$ of cobalt.

2. Sample weights of $0.1-0.2 \mathrm{~g}$ were Irradiated.

3. Prepared by dissolving $1 \mathrm{~g}$ of irradiated cobalt in conc. HCl and diluting to $100 \mathrm{ml}$ with water. Inactive cobalt content equal to $10 \mathrm{mgs}$ per milliliter; radioactive $c 0^{60}$ content equal to 0.1 microcuries per milliliter. This carrier solution is used to determine the chemical yield of the experiment.

4. Use a very small amount of water to effect the transfer; solution should be $6-8 \mathrm{M}$ in $\mathrm{HCl}$.

5. The ether extraction removes stable and radiactive iron from the solution.

6. Prepared by dissolving 1 gram of nftroso-naphthol in $40 \mathrm{ml}$ of glacial acetic acla and diluting to $80 \mathrm{ml}$ with water. The solution should be freshly 
prepared as required. If the solution is cloudy, it should be filtered.

7. In this instance, a 2-mm thick NaI crystal and a pulse helght analyzer was used for the radioactivity measurement.

8. The standard 1s a filter paper on which about $0.05 \mathrm{ml}$ of a solution of $\mathrm{Co}$ In dilute $\mathrm{HNO}_{3}$ ( $1 \mathrm{~g} \mathrm{Co} / \mathrm{liter}$ ) has been evaporated with an Infrared lamp. The test sample and the standard sample were 1rradiated not more than 10 apart in the reactor.

9. The $0.059 \mathrm{Mer}$ gamma photopeak, is used to measure the $0_{0}^{60 \mathrm{~m}}(10.5 \mathrm{~m})$ radioactivity. The 1.17 and $1.33 \mathrm{Mev}$ gamma photopeaks are used to measure the $\mathrm{CO}^{60}(5.27 \mathrm{y})$ radioact1vity.

\section{PROCEDURE 16}

Procedure Used In: Radioactivation Analysis

Method: Solvent extraction and precip1tation

Element Separated: $c 0^{60 \mathrm{~m}}(10.5 \mathrm{~m})$

Type of Materlal Analyzed: T1ssue and Vitamin $B_{12}$ solutions (284)

Type of Nuclear Bombardment: $\operatorname{co}^{59}(\mathrm{n}, \gamma) \mathrm{Co}^{60 \mathrm{~m}}$

Procedure by Kalser and Melnke (284)

Chemical Yleld of Carrler: 40\% (as a radloactlve carrler)

Separation Time: 15 minutes

Decontamination: Good

Equipment Required: Neutron source and standard laboratory equipment

Procedure:

\section{A. Irradiation of Samples}

1. Samples welghing $0.275-0.300 \mathrm{~g}$ were allowed to alr dry at room temperature for 24 hours and then placed in envelopes prepared from 4-m11 thick polyethylene $111 \mathrm{~m}$. The envelopes were closed by heat sealing.

2. The sealed samples were then 1rradiated in the "rabb1t" of the pneumatic tube system of the Ford Nuclear Reactor of the University of 
Michigan (Note 1) along with sultable monitoring folls (Note 2) for a period of 30 minutes at full reactor power.

\section{B. Radiochemical Separation}

1. During the 1rradiation, a nickel crucible was prepared containing $10 \mathrm{mg}$ of $\mathrm{Co}^{+3}$ carrier solution plus a known amount of $\mathrm{Co}^{60}(5.27 \mathrm{y})$ tracer (Note 3). Three sodium hydroxide pellets were added to the solution and the m1xture beated to near dryness. After cooling the solution, 10 grams of $\mathrm{Na}_{2} \mathrm{O}_{2}$ were added to the cructble and melted.

2. At the end of the 1rradiation, the 1rradiated sample was transferred from the polyethylene envelope to the cruclble and was fused in the melt mixture for 1 minute (Note 4). After cooling the mixture, (Note 5) the melt was dissolved in $50 \mathrm{ml}$ of distilled water (Note 6) and then 15-20 $\mathrm{ml}$ of glacial acet1c acld were added slowly to the solution (Note 7).

3. Th1s m1xture at a pH of 5-6 was transferred to a 150-ml separatory funnel containing $25 \mathrm{ml}$ of 8-hydroxyquinoline solution (3\% solution in chloroform) and shaken for 1 minute. The layers were allowed to separate and the aqueous layer discarded.

4. The cobalt was then extracted from the organic layer by adding $10 \mathrm{ml}$ of $9 \mathrm{M} \mathrm{ECl}$ to the separatory funnel and shaking for 1 mlnute.

5. After the layers separated, the organfc layer was discarded and cobalt preclpltated from the $\mathrm{BCl}$ solution by the addition of $\mathrm{Na}_{2} \mathrm{O}_{2}$. Th1s preclpitate was collected on a fliter chimney (Note 8 ), washed with water, and mounted for measurement on a gamma spectrometer.

\section{Radioact1vity Measurements}

1. The amount of $\mathrm{Co}^{60 \mathrm{~m}}$ (Note 8 ) was determined from the area under the $0.059 \mathrm{Mev}$ photopeak.

2. The amount of $\mathrm{Co}^{60}$ retalned (Note 3 ) on the precipitate was determined by measuring the 1.17 and $1.33 \mathrm{Mer}$ photopeaks. Th1s measurement was used to determine the chemical yield of the experiment.

3. Using the data obtained from the measurement of the gold folls (Note 2), data for the activation cross section for the reaction $\operatorname{co}^{59}(n, \gamma) \operatorname{co}^{60 m}$ and the 
half-life of $c 0^{60 m}$ and the absolute measurement of the co $0^{60 m}$ radioactivity, the amount of stable cobalt was determined.

\section{Notes:}

1. Thermal neutron flux equal to about $10^{12} \mathrm{n} / \mathrm{cm}^{2} / \mathrm{sec}$ when the reactor is operating at full power of 1 megawatt. The lower practical limit of detection for cobalt for these conditions was $5 \times 10^{-8} \mathrm{gram}$.

2. Gold folls, welghing between 0.5 and $1.0 \mathrm{mg}$ were wrapped in plastic envelopes and scotch taped to the inside cap of the "rabbit." Following the 1rradiation the folls were dissolved in $4 \mathrm{ml}$ of aqua regla and diluted to $10 \mathrm{ml}$ with distilled water. An aliquot of this solution was placed on a ftlter paper and mounted for measurement of the $0.411 \mathrm{Mev}$ gamma ray of $\mathrm{Au}^{198}$ on the spectrometer. Comparison with other measurements made with calibrated gold folls permitted normalization of all irradiations to a neutron flux of $1 \times 10^{12}$.

3. Added to determine chemical yield of experiment.

4. CAUTION: A cover must be used on the crucible since the reaction may be quite violent.

5. The outside of the cruclble was cooled by dipping it into a beaker of cold water. By manipulating the crucible during this cooling process, the melt was made to solidify lato a thin readily dissolved coating.

6. 50-70 $\mathrm{ml}$ of l1quid nitrogen were added to cool the solution to room temperature.

7. The solution was again cooled with liquid nftrogen.

8. 10-15 $\mathrm{ml}$ of $0.1 \mathrm{M} \mathrm{BCl}$ was added to prevent foaming. 
Procedure Used In: Radloactivation analys1s (Note 1)

Method: Precipitation

Element Separated: Cobalt

Type of Material Analyzed: Biological materials, (290) metals and alloys, $(60,296)$ etc.

Type of Nuclear Bombardment: $\operatorname{Co}^{59}(\mathrm{n}, \mathrm{y}) \mathrm{Co} 60$ (Co60: $5.27 \mathrm{y}$ )

Procedure by: Leddicotte, G.W. (Reported by Leddicotte $(297,298)$ )

Chemical Yield of Carrier: $60-70 \%$

Time of Separation: 3 hours

Degree of Purification: Greater than 105 from all other radioactive elements

Equipment Required: Neutron source and standard iaboratory equipment

\section{Procedure}

\section{A. Irradiation of Sample Material}

1. Irradiate known amounts of test (Note 2) and comparator (Note 3) sample in a neutron flux of at least $5 \times 10^{11} \mathrm{n} / \mathrm{sec} / \mathrm{cm}^{2}$ for 1 week or longer (Note 4). Use small quartz tubes, polyethylene bottles, or aluminum foll to contain the samples during the irradiation.

B. Preparation of Irradiated Samples for Analysis

1. The Comparator Sample

a. After the 1rradiation, quantitatively transfer the comparator sample (Note 3) to a $25 \mathrm{ml}$ volumetric flask. Dissolve it in $10 \mathrm{ml}$ of $12 \underline{\mathrm{M}} \mathrm{HCl}$ and dilute to volume with water. Pipet $0.5 \mathrm{ml}$ aliquot of this solution into a $50 \mathrm{ml}$ glass centrifuge tube. By means of a volumetric pipet, add to the same tube $1 \mathrm{ml}$ of standard cobalt carrier of known concentration (Note 5 ). Mix welI and continue with $\mathrm{S}$ tep $\mathrm{b}$ in Part 2 , below.

\section{The Test Sample}

a. After the Irradation, transfer the sample to a $50-\mathrm{ml}$ centrifuge tube. Plpet $1.0 \mathrm{ml}$ of standardized ccbalt carrier into the same tube and dissolve the sample in a minimum amount of $12 \mathrm{M} \mathrm{HCl}$. Add $10 \mathrm{mg}$. each of the following holdback carriers: Cu, Fe, Ni, Zr, Sr, and Na. 
b. Adjust the solution to $I M B C l$ and saturate the solution with $\mathrm{H}_{2} \mathrm{~S}$. Heat gently to coagulate the $\mathrm{Cu}_{2} \mathrm{~S}$, centrifuge, and transfer the supernate to another $50 \mathrm{ml}$ glass centrifuge tube. Discard the preclpitate. The supernate is boiled with $3 \mathrm{ml}$ of $16 \underline{\mathrm{M}} \mathrm{HNO}_{3}$ and $3 \mathrm{ml}$ of bromine water to oxidize the $\mathrm{Fe}^{++}$to $\mathrm{Fe}^{+++}$. Cool the solution and add $6 \mathrm{M} \mathrm{NH}_{4} \mathrm{OH}$ until there is no further precipitation of $\mathrm{Fe}(\mathrm{OH})_{3}$. Centrifuge and transfer the supernate to another $50 \mathrm{ml}$ glass centrifuge tube. Discard the precipitate.

c. Saturate the supernate with $\mathrm{H}_{2} \mathrm{~S}$ and precipitate $\mathrm{CoS}_{2}$ and NiS. Heat gently to coagulate the precipitate and centrifuge. Discard the supernate and wash the precipitate twice with $10 \mathrm{ml}$ portions of hot water. Dissolve the precipitate in $1 \mathrm{mi}$ of $16 \mathrm{M} \mathrm{HNO}_{3}$ and dilute to $15 \mathrm{ml}$ with $\mathrm{H}_{2} \mathrm{O}$. Boll to remove excess $\mathrm{H}_{2} \mathrm{~S}$.

d. Make the solution basic with $I \underline{\mathrm{M}} \mathrm{KOH}$ to precipitate $\mathrm{Co}(\mathrm{OH})_{2}$, centrifuge and discard the supernate. Wash the precipitate with dilute $\mathrm{KOH}$ solution ( 1 part of 1 M KOH to 10 parts water). Dissolve the $\mathrm{Co}(\mathrm{OH})_{2}$ in $3 \mathrm{ml}$ of $3 \underline{\mathrm{N}}$ acetic acid; add $\mathrm{N1}$ holdback carrler and dilute to $10 \mathrm{ml}$ with water. Heat to near bolling and add slowly 5 grams of solid $\mathrm{KNO}_{2}$ until $\mathrm{K}_{3} \mathrm{Co}\left(\mathrm{NO}_{2}\right)_{6} \cdot \mathrm{H}_{2} \mathrm{O}$ begins to form. Digest for 15 minutes in a hot water bath to complete the precipitation of $\mathrm{K}_{3} \mathrm{Co}\left(\mathrm{NO}_{2}\right)_{6}$. After precipitation is complete, cool and then centrifuge the mixture. Discard the supernate and wash the precipitate several times with $10 \mathrm{ml}$ portions of nitrite wash ( $5 \% \mathrm{KNO}_{2}$ acidified with acetic ac1d). Discard each wash solution.

e. Slurry the precipitate $1 \mathrm{n} 10 \mathrm{ml}$ of nitrite wash and filter with suction through a tared filter paper (Whatman No. 50) that is held in a Hirsch funnel. Wash with $5 \mathrm{ml}$ portions of water, alcohol and ether. Dry at $110^{\circ} \mathrm{C}$ for 5 minutes. Weigh as $\mathrm{K}_{3} \mathrm{Co}\left(\mathrm{NO}_{2}\right)_{6} \cdot \mathrm{H}_{2} \mathrm{O}$, and prepare for measurement (Note 6).

\section{c. Measurement of the Radioactivity of co60 and Calculation of} Inactive Cobalt Content of the Original Sample

1. The analysis of $\mathrm{co}$ is ccmpleted by measuring the $\mathrm{Co}^{60}$ by counting on a gamma scintillation spectrometer. Cobalt-60 has a half- 
life of 5.27 years and decays emitting gamma radiations of 1.17 and 1.33

Mev. The sum peak of $\mathrm{Co}^{60}$ is $2.5 \mathrm{Mev}$ and can be used if necessary.

2. Following the radioactivity measurements, the observed radioactivity is corrected for loss of "carrler" during the experiment and sample welghts of both the test and comparator sample. A comparison of these corrected radioactivitles becomes a measure of the stable cobalt content of the test sample:

Per cent of stable cobalt in test sample

$$
=\frac{\text { Co60 in test sample }}{\text { Co60 in comparator sample }} \times 100
$$

NOTES:

1. Th1s procedure has also been used to prepare radioactive $c_{0} 58$ tracer, produced by the nuclear reaction $\mathrm{Ni}^{58}(\mathrm{n}, \mathrm{p}) \mathrm{Co}^{58}$. co58 decays with a half-life of 72 days and emits 0.47 Mev positrons.

2. At least 0.10 gram portion of solid samples should be used.

3. Use Co-Al alloy (0.15\% cobalt) for cobalt comparator; approximately $25 \mathrm{mg}$ portions of the alloy should be used.

4. The Graph1te Reactor was used for this irradiation. The sens1tivity of the method is such that $5 \times 10^{-8}$ grams of cobalt can be determined. The sensitivity can be 1mproved by use of higher neutron fluxes.

5. As $\mathrm{Co}\left(\mathrm{NO}_{3}\right)_{2} \cdot 6 \mathrm{H}_{2} \mathrm{O}$, standardized to 10 mgs of cobalt per mill111ter of solution.

6. By comparing the final weight of the $\mathrm{K}_{3} \mathrm{Co}\left(\mathrm{NO}_{2}\right)_{6} \cdot \mathrm{H}_{2} \mathrm{O}$ precipitate obtained here with the theoretical yield expected for the amount of cobalt carrier added, it is possible to determine the chemical yield of the experiment. The chemical yield correction is then used to determine the amount of cobalt-60 recovered during the separation process. 
Frocedure Used In: Radioactivation Analysis

Method: Ion Exchange

Element Separated: $\mathrm{Co}^{60}(5.27 \mathrm{y})$ and/or $\mathrm{Co}^{58}(72 \mathrm{~d})$

Types of Mater1al Analyzed: Metals and alloys (296)

Type of Nuclear Bombardment: $\operatorname{co}^{59}(n, y) \operatorname{co}^{60}$

$\mathrm{N} 158(n, p) \mathrm{Co}^{58}$ (See Note 1 )

Procedure By: Leddicotte (Reported by Leddlcotte(298)) (See Kraus(195-199))

Chemical Yleld Carrier: 60-70\% (sometimes used as a carrler-free separation method)

T1me of Separation: 2 hours

Degree of Purlfication: $>10^{5}$ from all other species except co 58

Equipment Required: Neutron source and standard laboratory equipment

Procedure:

A. Irradiation of Sample Mater1al

1. Irradiate known amounts of test (Note 2) and comparator (Note 3)

sample in a neutron flux of at least $5 \times 10^{11} \mathrm{n} / \mathrm{sec} / \mathrm{cm}^{2}$ for 1 week or longer (Note 4). Use small quartz tubes, polyethylene bottles, or aluminum foll to contain the samples during the Irradiation.

\section{B. Preparation of Irradiation Samples for Analysis}

\section{The Comparator Sample}

a. After the irradiation, quantitatively transfer the comparator sample (Note 3) to a $25 \mathrm{ml}$ volumetric flask. Dissolve it in $10 \mathrm{ml}$ of $12 \mathrm{M}$ ECl and dilute to volume with water. Plpet $0.5 \mathrm{ml}$ allquot of this solution Into a $50 \mathrm{ml}$ glass centrifuge tube. By means of a volumetric pipet, add to the same tube $1 \mathrm{ml}$ of standard cobalt carrier of known concentration (Notes 5 and 6). Mix well, then evaporate to near dryness; add sufficient acid to make the solution $10 \mathrm{M}$ in $\mathrm{HCl}$ (Note 7). M1x well and continue with Step $\underline{b}$ in Part 2 below.

\section{The Test Sample}

a. After the 1rradiation, quantitatively transfer the sample to a $50-\mathrm{ml}$ centrifuge tube and by means of a volumetric plpet, pipet $1.0 \mathrm{ml}$ of 
standardized cobalt carrier (Notes 5 and 6 ) into the same tube and dissolve the sample in a minimum amount of $12 \mathrm{M} \mathrm{HCl}$. Mix well, then evaporate to near dryness. Add sufficient acld to make the solution $10 \mathrm{M}$ In HCl (Note 7).

b. Transfer the solution to a anion exchange resin column (Note 8 ).

c. Elute the column with at least $25 \mathrm{ml}$ of $10 \mathrm{M} \mathrm{HCl}$ (Note 7).

Collect the effluent and discard 1 t.

d. Elute the $\mathrm{Co}^{60}$ (or $\mathrm{Co}^{58}$ ) from the column with at least $25 \mathrm{ml}$ of 4-5 $\underline{M}$ BCl. Collect the effluent in a suitable contalner (Note 9).

e. Evaporate the cobalt effluent to a small volume and mount for counting (Note 10).

C. Measurement of the Radioactivity of $\mathrm{Co}^{60}$ and Calculation of Inactive Cobalt Content of the Original Sample

1. The analysis of $\mathrm{Co}$ 1s completed by measuring the $c 0^{60}$ by counting on a gamma scintillation spectrometer. Cobalt-60 has a half-life of 5.3 years and decays emftting gamma energies of 1.17 and $1.33 \mathrm{Mev}$. The sum peak of $\mathrm{co}^{60}$ 1s $2.5 \mathrm{Mev}$ and can be used if necessary.

2. Following the radioactivity measurements, the observed radioactivity Is corrected for loss of "carrler" during the experiment (Note 11) and sample welghts of both the test and comparator sample. A comparison of these corrected radioactivities becomes a measure of the stable cobalt content of the test sample (Note 12).

Per cent of stable cobalt in test sample

$$
=\frac{\mathrm{Co}^{60} \text { in test sample }}{\mathrm{Co}^{60} \text { in comparator sample }} \times 100
$$

Notes:

1. This procedure has also been used to prepare radioactive $\operatorname{co} 58$ tracer, produced by the nuclear reaction $N 1^{58}(n, p) c 0^{58}$. c 058 decays with a half-life of 72 days and em1ts $0.47 \mathrm{Mev}$ positrons and $0.81 \mathrm{Mev}$ and $1.62(\sim 1 \%)$ Mev gamma radiations in its decay. The positron decay is accompanied by annihilation garma radiations of $0.51 \mathrm{Mev}$. Th1s procedure has also been used to determine trace nickel in sample materlals. In that work, the observed $\mathrm{Co}^{58}$ radioactivity is a measure of the stable nickel content of the sample. 
2. At least 0.10 gram portion of solid samples should be used.

3. Use 25 gms of Co-Al alloy (0.15- cobalt) for cobalt comparator for determination of stable cobalt.

4. The graphite reactor was used for this irradiation. The sensitivity of the method is such that $5 \times 10^{-8}$ grams of cobalt can be determined. The sensitivity can be improved by use of higher neutron fluxes.

5. As $\mathrm{Co}\left(\mathrm{NO}_{3}\right)_{2} \cdot 6 \mathrm{H}_{2} \mathrm{O}$, standardized to 10 mgs of cobalt per mlliliter of solution.

6. If this procedure is used in a carrier-free separation, omit the adition of cobalt carrier.

7. 12 MCl can also be used here.

8. Dowex-1, $10 \%$ crosslinkage, 50-100 mesh, resin packed in a Pyrex glass column, $0.5^{\prime \prime}$ in dlameter $\times 12 "$ long. Column conditioned with $10 \underline{\mathrm{M}}$ or $12 \mathrm{M} \mathrm{BC}$.

9. Further elution of the column with a volume $0.5 \mathrm{M} \mathrm{HCl}$ will remove $\mathrm{Fe} 59$ radioactlvity, if present.

10. Quant1tative recovery of cobalt carrler assumed here. If desired, solution may be processed in the manner described in Steps $\underline{b}$ through $\underline{e}$ of Section B-2 of Procedure 17 of this Monograph.

11. Not required if cobalt carrler is not used.

12. Does not apply if $\mathrm{Co}^{60}$ or $\mathrm{Co}^{58}$ is being prepared.

PROCEDURE 19

Procedure Used In: Radioactivation Analysis

Method: Precipitation

Element Separated: $C_{0}^{60}(5.27 \mathrm{y})$

Type of Materlal Analyzed: Sodium potassium alloys (299)

Type of Nuclear Bombardment: $\operatorname{Co}^{59}(n, \gamma) \mathrm{Co}_{0} 60$

Procedure by Smales, A. A. (299)

Chemfcal Yleld: Quant1tative

Separation T1me: Several hours 
Decontamination: Complete from other radioactive species

Equipment Required: Neutron Source and Standard Laboratory Equipment Procedure:

1. Dissolve 1rradiated alloy in methyl alcohol (Note 1) and then acidify the solution with hydrochloric ac1d.

2. To the solution, add 20 mgs of cobalt carrier and 5 mgs of $\mathrm{Fe}^{+3}$. Bo1l the solution gently on a hotplate for ten minutes.

3. After cooling, dilute the solution to $250 \mathrm{ml}$ with water; then add a slight excess of a suspension of zinc oxide in water. Digest for ten minutes; filter through a $15-\mathrm{cm}$ Whatman No. 541 filter paper. Discard the prec1pitate.

4. Bo1l the filtrate and add dropwise $7.5 \mathrm{mI}$ of a solution contalning 1 of $\alpha$-nitroso $\beta$-naphthol in $15 \mathrm{ml}$ of glacial acetic acid. Boll for two minutes; f11ter through an $11-\mathrm{cm}$ Whatman No. 31 f1lter paper. D1scard the filtrate. Wash the preclpitate thoroughly with hot water; dry and Ignite the f1lter paper and contents in a silica crucible, at $800^{\circ} \mathrm{C}$.

5. After cooling, dissolve the 1gnited residue 1 in $5 \mathrm{ml}$ of hydrochloric ac1d (spec1f1c grav1ty 1.18), by warming gently on a hot-plate. Transfer the solution to a $50 \mathrm{ml}$ centrifuge tube, add I ml of a solution containing I mg of ferric 1ron and a slight excess of ammonlum hydroxide (specific grav1ty 0.88). Boll gently; filter through a 9-cm Whatman No. 40 filter paper into a $150 \mathrm{ml}$ beaker. Wash the preclpitate w1th $5 \mathrm{ml}$ of hot water. Discard the precipitate.

6. To the filtrate, add KOH solution ( 4 grams $\mathrm{KOH} 1 \mathrm{n} 10 \mathrm{ml} \mathrm{H}_{2} \mathrm{O}$ ) and boll gently until all the ammonia is driven off. Transfer the solution and precipitate to a centrifuge tube with water. Centrifuge and decant the washings.

7. Dissolve the precipltate in $5 \mathrm{ml}$ of $3 \mathrm{M}$ hydrochloric acid (Note 2). Then add $5 \mathrm{ml}$ of glacial acetic acld and dilute to $25 \mathrm{ml}$ wlth water. Prec1pitate $\mathrm{K}_{3} \mathrm{Co}\left(\mathrm{NO}_{2}\right)_{6}$ by adding solid $\mathrm{KNO}_{3}$ unt1l precipltation is complete. Digest for flve minutes; then centrifuge; discard the supernatant liquid. 
Wash the precipltate w1th water and ethyl alcohol, centrifuglng after each wash. Discard the washes.

8. Transfer the precipitate to a tared counting tray and evaporate to dryness under an Infra-red lamp. Welgh the sample as potassium cobaltinitrite and determine the chemical yield.

9. Count the sample and standard under a normal end-window Gelger-Mueller counter. Correct for self-absorption, beckeround, and chemlcal yield.

10. Check the radiochemical. purity by absorption measurement.

\section{Notes:}

1. Irradlated materlal dissolution was made in a dry box under a nitrogen atmosphere.

2. Heat mixture gently unt1l a solution is obtained.

\section{PROCEDURE 20}

Procedure Used In: Radoactivation Analysis

Method: Precipitation

Element Separated: $\mathrm{Co}^{60}(5.27 \mathrm{y})$

Type of Materlal Analyzed: Nickel cathodes (303)

Type of Nuclear Bombardment: $\operatorname{co}^{59}(n, y) \mathrm{Co}^{60}$

Procedure By: Deblesse, et al (303)

Chemical Y1eld of Carrier: Not indicated

Separation Time: Not Indicated

Decontamination: Excellent

Equipment Required: Neutron source and standard laboratory equipment

\section{Procedure:}

1. Following an irradiation in the Chatillion reactor for 180 hours, the samples were dissolved In hydrochlorlc acld and inactive cobalt and the Co 60 precipitated with $\alpha$-nitroso $\beta$-naphthol.

2. The precipitate was collected and washed and the 0.308 Mev beta 
radiations from $C 0^{60}$ measured by means of a Gelger-Mueller counter.

Cobalt concentrations of the order of $0.28 \%$ cobalt in the nickel cathodes were determined by this analysis method.

\section{PROCEDURE 21}

Procedure Used In: Radioactivation Analysis

Method: Precipitation (chiefly)

Element Separated: $C_{0}^{60}(5.27 \mathrm{y})$

Type of Materlal Analyzed: Sodium metal (304)

Type of Nuclear Bombardment: $\operatorname{co}^{59}(n, r) \mathrm{Co}^{60}$

Procedure By: Grand, et al $(304)$ using radiochemical separation procedures reported by Meinke $(288)$ and Klelnberg $(289)$. (See Procedures 3-11 and 13)

Chemical Yield of Carrier: As Indicated in adapted procedures $(288,289)$

Separation Time: Several hours

Decontamination: Excellent from $\mathrm{Na}^{24}(15 \mathrm{~h}), \mathrm{Mn}^{54}$ (300 d), $\mathrm{Ta}^{182}$ (112 d), and $\mathrm{Cr} 51$ (27 d)

Equipment Required: Neutron source and standard laboratory equipment

Procedure:

1. Samples and cobalt monitors 1rradiated in Materials Testing Reactor.

2. The radiochemical procedure involved complete solution of the sample, addition of inactive carrlers and treatment with $\mathrm{HF}_{-}-\mathrm{HNO}_{3}-\mathrm{H}_{2} \mathrm{SO}_{4}$ mixture and $\mathrm{H}_{2} \mathrm{O}_{2}$. Following this treatment, gross separations of the elements were made by adaptations of procedures reported by Meinke ${ }^{(281)}$ and Kleinberg (282).

3. A known welght (about $50 \mathrm{mg}$ ) of the separated material was mounted In a reproducible manner on a plastic holder using a trace of collodion as a binder. The samples were counted on standard $\beta$-counting equipment.

4. Limits of measurement for this analysis: $0.002 \mathrm{ppm}$. 
Procedure Used In: Radloactivation analysis

Method: Ion exchange

Element Separated: $\mathrm{Co}^{60}(5.27 \mathrm{y})$

Type of Materlal Analyzed: $18 / 8$ steel (305)

Type of Nuclear Bombardment: $\operatorname{co}^{59}(n, \gamma) \mathrm{Co}^{60}$

Procedure By: Monnier, et al (305) (Note 1)

Chemlcal Yleld of Carrier: Carrler-free

Degree of Puriflcation: Excellent from stable chromlum, manganese, n1ckel, s1licon, carbon, molybdenum, and iron. Only radioactive contaminant obtalned in separation was $\operatorname{co5} 8$ ( 72 d) produced by the reaction $N 158(n, p) \operatorname{co} 58$. Interference eas 1 ly resolved by gamma spectrometry.

Equipment Required: Neutron source and standard laboratory equipment

Procedure:

A. Irradiation of Samples

1. Irradiate test samples (Note 2) in a neutron source for a predetermined t1me (Note 3).

2. After the irradiation, dissolve the sample in $15 \mathrm{ml}$ of HCl and dilute with water to a $100-\mathrm{ml}$ volume to obtain a $9 \mathrm{M} \mathrm{HCl}$ solution.

3. Take a $1 \mathrm{ml}$ aliquot of this solution and $\mathrm{mix}$ with $10 \mathrm{ml}$ of $9 \mathrm{M} \mathrm{HCl}$. Transfer this solution to an ion exchange resin colum (Note 4 ).

4. Elute the column with a $11-\mathrm{ml}$ volume of $9 \mathrm{M}$ HCl (Note 5).

5. Continue the elution with an additional $20-\mathrm{ml}$ of the $9 \mathrm{M} \mathrm{HCl}$ solution (Note 5).

6. Change the molarity of the eluting reagent to $4 \mathrm{M} \mathrm{HCl}$ and continue elution unt1l 32-ml of the $4 \underline{\mathrm{M}} \mathrm{ECl}$ has passed through the column (Note 5 ).

7. Change the molarity of the eluting reagent to $0.5 \mathrm{M} \mathrm{BCl}$ and continue elution unt1l a 10-ml volume has passed through the column.

8. Evaporate this solution to dryness in the presence of $1 \mathrm{ml}$ of $5 \%$ Nacl solution. Then measure its radioactivity.

9. Measure the $\mathrm{Co}^{60}$ (and $\mathrm{Co}^{58}$ ) gamma radioactivity by means of a $5 \mathrm{~cm} \mathbf{x}$ $5 \mathrm{~cm}$ NaI crystal and a pulse helght analyzer.

10. Obtain the co 60 disintegration rate in the test sample by comparing the gamma radiations at 1.17 and $1.33 \mathrm{Mev}$ with those observed in a calibrated 
co60 standard (Note 6) measured under the same count1ng conditions.

11. Calculate the amount of stable cobalt in the test sample by the absolute method of calculations (Note 7).

Notes:

1. See Leddicotte $e^{(298)}$ for additional information on separation of co60 (and $\mathrm{co}^{58}$ ) by an ion exchange technique.

2. At least 0.40 gram of $18 / 8$ steel was irradiated.

3. The p1le at the University of Geneva (Switzerland) was used for these irradiations. Length of Irradiation about 45 days.

4. $8 \%$ cross-Iinked Dowex-I Ion exchange resin was used. Dimensions of column: $12 \mathrm{~cm}$ hlgh $\times 6 \mathrm{~cm}$ in diameter. Column was conditioned with $9 \mathrm{M} \mathrm{HCl}$.

5. This volume was collected in a suitable container and its radioactivity measured on a $\gamma$-spectrometer. Showed presence of radioactive contaminants from activation of $\mathrm{Cr}, \mathrm{Fe}$, etc.

6. In this instance, a co ${ }^{60}$ solution obtalned from the Isotope Division, Atomlc Energy Research Establishment (AFRE), Harwell, England.

7. In this method, the following equation, was used:

$$
W=\frac{A M}{\left(6.02 \times 10^{23}\right)(f)\left(\sigma_{\text {ac }}\right)(\theta)(S)(D)}
$$

where

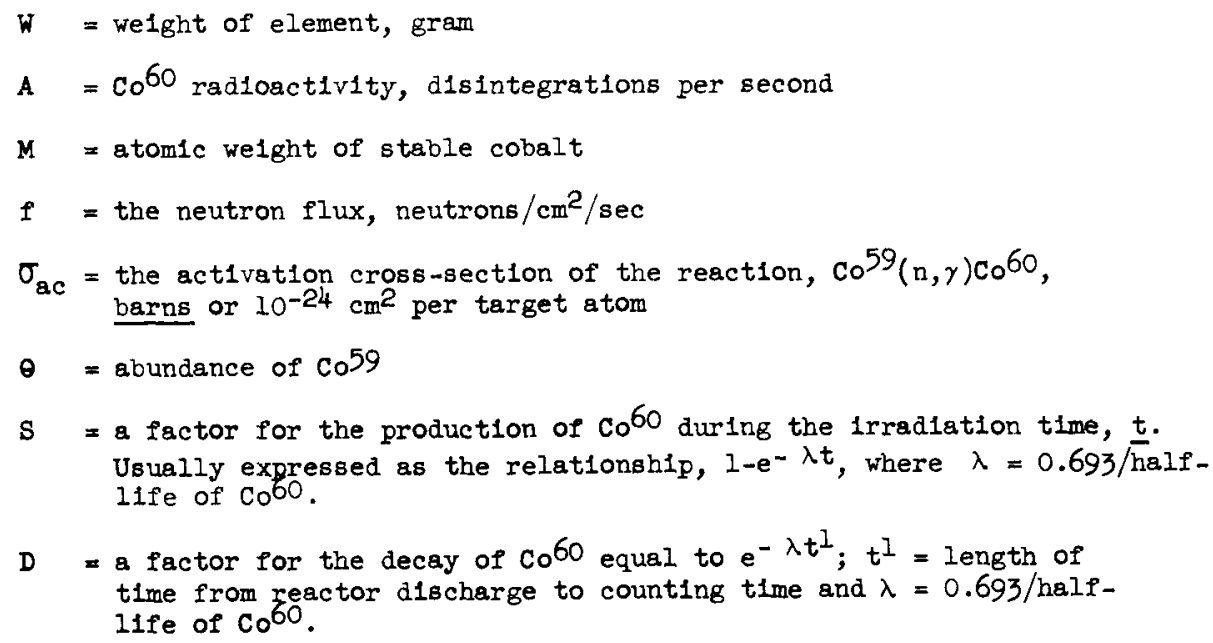


Procedure Used In: Radioactivation analysis

Method: Precipitation

Element Separated: $\quad c^{60}(5.27 \mathrm{y})$

Type of Materlal Analyzed: Iron meteor1tes (306)

Type of Nuclear Bombardment: $\operatorname{co}^{59}(n, \gamma) \mathrm{Co}^{60}$

Procedure By: Goldberg, et al, (306) adapted from a procedure by Young

Chemical Y1eld of Carrier: Quantitative

Degree of Purification: Excellent

Equ1pment Required: Neutron source and standard laboratory equipment

Procedure:

1. Place the samples in a suitable contalner for Irradiation (Note 1 ).

2. After the 1rradiation, dissolve approximately $0.3 \mathrm{~g}$ of the meteorite In a minimum amount of aqua regla.

3. Add $10 \mathrm{ml} 6 \mathrm{M} \mathrm{HCl,}$ then dilute volume three-fold.

4. Heat and pass in $\mathrm{H}_{2} \mathrm{~S}$ unt1l precipitation is complete.

5. Filter and wash preclp1tate w1th $\mathrm{H}_{2} \mathrm{~S}$ wash solution. Discard precipltate (Note 2).

6. Boll the solution to eliminate $\mathrm{H}_{2} \mathrm{~S}$.

7. Add sodium phosphate reagent to the solution (Note 3 ).

8. Add conc. $\mathrm{NH}_{4} \mathrm{OH}$ to solution unt1l a $\mathrm{pH}$ of 5.5 is reached (Note 4 ).

9. Add glacial acetic ac1d until a pH of 3.5 is reached (Note 5).

10. Readjust $\mathrm{pH}$ to 3.5 with concentrated ammonium hydroxide.

11. Bring solution to bo1l, allow to settle, then filter through a fritted Buchner.

12. Wash with acet1c ac1d wash solution at least five times (Note 6).

13. Make filtrate acidic with $\operatorname{HCl}$ (Note 7).

14. Add Ireshly prepared $\alpha$-nitroso- $\beta$-naphthol reagent (Note 8 ).

15. Digest at low heat, cool, and fllter.

16. Wash precipitate several times with hot $5 \% \mathrm{HCl}$, then several times with hót water.

17. Dry the precipitate in plat:num crucible and ignite in muffle oven at $800^{\circ} \mathrm{C}$ (Note 9). 
18. Dissolve the residue in $1: \mathrm{I}_{2} \mathrm{SO}_{4}$ and transfer to a weighed porcelain cructble.

19. Evaporate carefully, then ignite at $550^{\circ} \mathrm{C}$ in a muffle oven.

20. Cool and weigh residue as cobalt sulfate.

21. Mount for counting on suitable radiation counter (Note 10).

\section{Notes:}

1. Authors do not indicate size of sample irradiated, place of 1rradation, and length of irradiation.

2. Ac1d-sulfide insoluble salts removed in this step.

3. Reagent: $34.05 \mathrm{~g}$ of tri-sodium phosphate heptahydrate in one liter of water. $10 \mathrm{ml}$ of reagent precipitates $0.05 \mathrm{~g}$ of iron. The solution is usually cream-colored after addition of the reagent, although it may be a clear yellow solution if the acid concentration is high.

4. Solution w1ll be blue-grey.

5. Solution will be grey-white.

6. Reagent: $25 \mathrm{ml}$ conc. acetic ac1d in $1000 \mathrm{ml}$ of water.

7. $3 \mathrm{ml}$ of $6 \mathrm{M} \mathrm{HCl}$ for every $100 \mathrm{ml}$ of solution.

8. Reagent: 10 gram of $\alpha$-n1troso- $\beta$-naphthol (Eastman Kodak) in $100 \mathrm{ml}$ of $1: 1$ acetlc acid. Approximately $0.5 \mathrm{~g}$ of $\alpha$-nitroso- $\beta$-naphthol are required for every $0.01 \mathrm{~g}$ of cobalt. The cobalt precipitate 1 s brickred. If copper is present, the precipitate is brown.

9. The 1gnition should not take place at a temperature greater than $900^{\circ} \mathrm{C}$ or less than $750^{\circ} \mathrm{C}$.

10. No specific information given on radioactivity measurement method or method of resolving data. Concentrations of gobalt as small as $0.53 \%$ were determined by this method. 
PROCEDURE 24

Procedure Used In: Radioactivation Analysis

Method: Precipitation

Element Separated: $\mathrm{Co}^{60}(5.27 \mathrm{y})$

Type of Materlal Analyzed: Meteor1tes, $(307,308)$ rocks and minerals, $(307,309,310)$ marine sediments $(307,311)$

Type of Nuclear Bombardment: $\operatorname{co}^{59}(n, y) \mathrm{Co}^{60}$

Procedure By: Smales, et al ( 307 )

Chemfcal Y1eld of Carrier: Quantitative

Time of Separation: Several hours

Degree of Purification: Excellent

Equipment Required: Neutron source and standard laboratory equipment

Procedure:

A. Irradiation of Sample Materials

1. Irradlate known welghts of test (Note 1) and standard (Note 2) samples In a neutron flux (Note 3) for at least one (1) week.

B. Radiochemical Separation

1. After 1rradiation, transfer the samples to 150-ml beakers and add standardized nickel, copper, and cobalt carriers (Note 4) and $5 \mathrm{ml}$ of $\mathrm{HCl}$ (sp. $\mathrm{gr} .1 .18$ ). Heat gently on a hot plate until the solids have dissolved (Note 5).

2. Allow the solution to cool and then dilute 1 t to $80 \mathrm{ml}$ with water; add $100 \mathrm{mg}$ of $\mathrm{Fe}^{+3}$, as ferric ammonium sulphate solution, $10 \mathrm{ml}$ of a 10 percent solution of sodium nitrate, $5 \mathrm{ml}$ of 40 percent $\mathrm{w} / \mathrm{v}$ solution of ammonlum citrate and ammonfum hydroxide in slight excess. Preclpitate the nickel by adding slowly $10 \mathrm{ml}$ of a 1 percent $\mathrm{w} / \mathrm{v}$ solution of dimethylglyoxime in methanol, and collect the precipitate on a Whatman No. 541 filter-paper (Note 6).

3. To the filtrate add dilute nitric acld until the solution is just ac1d, and then heat to $80^{\circ} \mathrm{C}$ and add $10 \mathrm{ml}$ of a freshly prepared $1 \%$ solution of thlonalde in methanol. Place the beaker on a hot-plate, st1rring unt1l coagulation of the precipitate is complete, and then collect it on a whatman No. 541 f1lter-paper (Note 7). 
4. To the f1ltrate from the copper thionalde precip1tation add $20 \mathrm{ml}$ of $\mathrm{HNO}_{3}$ (sp. gr. 1.42) and evaporate to dryness. Then add $10 \mathrm{ml}$ of $\mathrm{H}_{2} \mathrm{SO}_{4}$ (sp. gr. 1.84) and evaporate to fumes of sulphurle ac1d. Add additional quantitles of $\mathrm{HNO}_{3}$ and treat strongly to destroy completely all of the organic matter. After cooling the solution, dilute 1t to $250 \mathrm{ml}$ with water, add a suspension of zinc oxide in water until preclpitation occurs and then a slight excess, and set aside for 10 minutes before collecting the precipitate on \& 15-cm Whatman No. 541 f1lter-paper. Discard the precip1tate.

5. Heat the filtrate, and add dropwise $5 \mathrm{ml}$ of a 10 percent solution of 1-nitroso-2-naphthol in glacial acetic acid, and boll for 2 minutes. Collect the precipltate on an $11-\mathrm{cm}$ Whatman No. 31 filter-paper, and wash 1 t thoroughly with hot water. Discard the filtrate.

6. Transfer the precipltate to a silica cruclble. Ignite the cructble and 1 ts contents in a muffle furnace at $800^{\circ} \mathrm{C}$. Cool and then dissolve the oxlde resldue in $5 \mathrm{ml}$ of $\mathrm{HCl}$ (sp. gr. 1.18), warming if necessary. Make a "scavenging" preclpitation by adding a few milligrams of ferric 1ron, precipitating 1t with ammonlum hydroxide. Collect the prec1pitate on a Whatman No. 541 fliter-paper. D1scard the preclpitate.

7. To the filtrate add $10 \mathrm{ml}$ of a. $40 \% \mathrm{w} / \mathrm{v}$ solution of KOH and carefully boll the solution until all the ammonia is expelled. Centrifuge the mixture; discard the supernatant liquid.

8. Dissolve the precipltate in $5 \mathrm{ml}$ of $3 \underline{M}$ HCl solution, transfer it to a $150-\mathrm{ml}$ beaker, and add $15 \mathrm{ml}$ of water, $5 \mathrm{ml}$ of glaclal acetic actd, and $5 \mathrm{ml}$ of $60 \% \mathrm{w} / \mathrm{v}$ solution of potassium nitrite. Digest the solution for 5 minutes, then centrifuge. Discard the supernatant liquid.

9. Wash the precipltate with water and ethanol. Then, by slurrying 1t with a small amount of ethanol, transfer 1t to a welghed aluminum counting tray. Dry the tray and 1 ts contents under an infra-red lamp. Determine the chemical yleld by welghing as potassium cobaltinitrite. 


\section{c. Co60 Radioactivity Measurement and Determination of Stable Cobalt}

1. Count all samples and standards on sultable radiometric equipment, make any corrections necessary for background, self-absorption, and chem1cal yield. Calculate the stable cobalt content of the test samples by comparing the $\mathrm{co}^{60}$ radioactivity found in both the test and standard samples (Note 8 ).

2. Check the radiochemical purity of the samples elther by decay, by beta-absorption curves, or by gamma-ray spectrometry.

\section{Notes:}

1. Samples of varled welghts were sealed In short lengths of polyethylene tubing.

2. Portions of a mild steel sample contalning 0.016 percent cobalt were used as standard samples. These were also sealed in short lengths of polyethylene tubing. After the 1rradiation, dissolve the standards In $\mathrm{HCl}_{-} \mathrm{HNO}_{3}$. To the solution add $10.0 \mathrm{mg}$ of cobalt in solution and treat as for the test samples .

3. The "self-serve" and thermal column positions of the Harwell P1le were used for these Irradiations.

4. Carriers used contained $10.0 \mathrm{mg}$ of alckel in the form of nlckel n1trate solution, $20.0 \mathrm{mg}$ of copper as copper sulphate solution and 10.0 mg of cobalt as cobalt nitrate solution.

5. This treatment is adequate for the dissolution of the marine sediments. Meteorite and rock samples were dissolved in the following manner: "To these samples add $5 \mathrm{ml}$ of $\mathrm{HNO}_{3}$ ( $\mathrm{sp} . \mathrm{gr} .1 .42$ ) and $10 \mathrm{ml}$ of $\mathrm{HClO}_{4}$ (sp. gr. 1.70) and evaporate to fumes of perchlorle acid. Allow to cool, and then add $5 \mathrm{ml}$ more of the $\mathrm{HNO}_{3}$ and 10-20 drops of $40 \% \mathrm{w} / \mathrm{w}$ hydrofluric actd. Evaporate to fumes of perchloric acid; $c 001$, and then add $5 \mathrm{ml}$ of aqua regia and again evaporate to fumes of perchloric acid. If necessary, repeat this 
treatment should any 1nsoluble residue remain at th1s stage. Then, proceed w1th Step 2 of Part B of the Procedure."

6. Th1s precipitate may be processed for nickel (See Smales, et al (307)).

7. Th1s precip1tate may be processed for copper (See Smales, et al (307)).

8. At least $10^{-8}$ gram of cobalt can be determined by this method. 


\section{REFERENCES}

1. Strominger, D., Hollander, J. M., and Seaborg, G. T., Table of Isotopes, Review of Modern Physics, 30, No. 2, Part 2 (1958).

2. Hughes, O. J. and Schwartz, R. B., Neutron Cross Sections, BNL-325, 2nd Edition (1958).

3. Centre d'Information du Cobalt, Cobalt Monograph, p. 122, Centre d'Information, Brussels, 1960.

4. Latimer, W. M., Oxidation Potentials, and ed., p. 210-214, PrenticeHall, Inc., New York, 1952.

5. Akimov, G. W. and Clark, G. B., Trans. Faraday Soc. 43, 679 (1947).

6. Glasstone, S., J. Chem. Soc. 1926, p. 2887.

7. Newberry, E., J. Chem. Soc. 109, p. 1051 (1916).

8. Verdieck, R., Ksycki, M. J., and Yntema, L. F., Trans. Electrochem. Soc. 80, p. 41-54 (1941).

9. Schwabe, K., Comptes Rendus de la 9th Reunion du Comite International de Thermodymamique et Cinetique Electrochimique, Paris, 1957, p. 339, Butterworth, Iondon, 1959.

10. El Wakkad, S. E. S., and Hickling, A., Trans. Faraday Soc. 46, p. 820-824 (1950).

11. Sneed, M. C. and Maynard, J. L., General Inorganic Chemistry, p. 1081-1087, Van Nostrand, New York, 1942.

12. Holness, H., Advanced Inorganic Qualitative Analysis by Semi-Micro Methods, p. 93-95, Pitman, London, 1957.

13. Handbook of Chemistry and Physics, 36th ed., Chemical Rubber Co., 1954-1955.

14. Gmelins' Handbook der Anorganischen Chemie, System No. 58, Kobalt, 8th ed., Part B: "Cobalt Ammines," Verlag Chemie G. M. b. H., Berlin, 1930 .

15. Rodd, E. H., Chemistry of Carbon Compounds, p. 442, Elsevier Press, London, 1952.

16. Kharasch, M. S., and Fields, E. K., J. Am. Chem. Soc. 63, p. 2316 (1941).

17. Briggs, D. A. E. and Polya, J. B., J. Chem. Soc: 1951, p. 1615. 
18. Ingles, D. L. and Polya, J. B., J. Chem. Soc. 1949, p. 2280.

19. Coates, G. E., Organometallic Compounds, p. 181, Methuen, London, 1956.

20. Duval, C., Inorganic Thermogravimetric Analysis, p. 206-222, Elsevier, Amsterdam, 1953.

21. Strebinger, R. and Pollak, J., Mikrochim. 4, 16 (1926).

22. Dakin, H. D., Z. Anal. Chem. 39, 789 (1900).

23. Fischer, N. W., Pogg. Ann. 72, 477 (1847).

24. Nenedkevich, K. A. and Saltykova, v. S., Zhur. Anal. Khim. 2, 123 (1946).

25. Lamure, J., Bull. Soc. Chim. France 13, 661 (1946).

26. Sierra, F. and Carceles, F., Anales Fis Quim. 47B, 281 (1951).

27. Idem, 1bid., 341 .

28. Idem, Ibid., 811.

29. Korenman, I. M., Sheyanova, I. M., and Barychnikova, M. N., Zhur. obsche1. Khim. 26, 365 (1956).

30. Wenger, P. E., Cimeran, C., and Corbøz, A., Mikrochim. Acta. 2, 314 (1938).

31. Shennan, R. J., Smith, J. H. F., and Ward, A. M., Analyst 61, 395 (1936).

32. Shennan, R. J., J. Soc. Chem. Ind. 61, 164 (1942).

33. Guhe-Sircar, S. S. and Bhattacharjee, S. C., J. Indian Chem. Soc. $28,155(1941)$.

34. Berg, R., Z. Anal. Chem. 76, 191 (1929).

35. Tsinberg, S. L., Zavodskaya Lab. 6, 1009 (1937).

36. Willard, H. H. and Hall, D., J. Am. Chem. Soc. 44, 2219 (1922).

37. Zimmerman, C., Ann. 232, 335 (1886).

38. Anand, V. D. and Dechmukh, S., Z. J. Anal. Chimie 172, 264-8 (1960).

39. Williams, W. J., Talanta ․, 88-104 (1958).

40. Hillebrand, W. F., Lundell, G. E. F., Bright, H. A., and Hoffman, J. I., Applied Inorganic Analys1s, and Ed., p. 417-424, J. Wiley and Sons, New York, 1953.

41. Flagg, J. F., J. Am. Chem. Soc. 63, 3150 (1941).

42. Britton, H. T. S., Hydrogen Ions, 4th Ed., Van Nostrand, New York, 1956.

43. Lundell, G. E. F. and Knowles, H. B., J. Am. Chem. Soc. 45, 680 (1923).

44. Young. R. S. and Hall, A. J., Ind. Eng. Chem., Anal. Ed. 18, 262 (1946).

45. North, v. and Wells, R. C., Ind. Eng. Chem., Anal. Ed. 14, 859 (1942). 
46. Hillebrand, W. F., et al., op. cit., p. 418.

47. Hoffman, J. I., J. Research Nat1. Bur. Standards I, 883 (1931).

48. Hillebrand,W. F., et al., op. cit., p. 85.

49. Hillebrand, W. F., et al., op. cit., p. 89.

50. Auger, V., LaFontaine, L., and Corpan, C., Compt. Rend. 180, 376 (1925).

51. Burgess, G., Z. Angew. Chem. 2, 596 (1896).

52. Von Knorre, G., Z. Angew. Chem. 264 (1893).

53. Mayr, C. and Feigl, F., Z. Anal. Chem. 90, 15 (1932).

54. Hillebrand, W. F., et al., op. cit., p. 408-412.

55. Hillebrand, W. F., et al., op. cit., p. 440-441.

56. Bogshaw, B., Analyst 84, 475-504 (1959).

57. Westermark, T. and Fineman, T., Proceedings, 2nd Conference on Peaceful Uses of Atomic Energy, 1958, 28, 506, United Nations, New York, 1959.

58. Williams, W. J., op. cit., p. 90.

59. Fischer, N. W., Pogg. Ann. 72, 477 (1847).

60. Brooksbank, W. A., Ieddicotte, G. W., and Dean, J. A., Anal. Chem. 30, 1785 (1958).

61. Kallmann, S., Anal. Chem. 22, 1519 (1950).

62. Smith, R. R., Passell, T. O., and Reeder, S. D., "Radiochemical Analyses for $\mathrm{Fe}, \mathrm{Cr}, \mathrm{N} 1$ and $\mathrm{Co}$ in Corrosion Products," USAEC Report No. AECD-3889 (1955).

63. Broughton, D. B., Laing, M. E., and Wentworth, R. I., Anal. Chem. 19, 72 (1947).

64. Horowitz, 0., Anal. Chem. 20, 89 (1948).

65. Baker, L. C. W. and McCutchen, T. P., Anal. Chem. 22, 944 (1950).

66. Sinha, S. K. and Shome, S. C., Anal. Chimica Acta. 21, 459 (1959).

67. Wahamatsu, s., Japan Analyst 6 , 426 (1957).

68. Spacu, G. and Gheorghui, C., Analele Univ., C. I. Parhon Bucuresti 10, 51 (1956).

69. Andrew, T. R. and Gentry, C. H. R., Metallurgia, 60, 357 (1959).

70. Pestea, I. and Antonescu, E., Rev. Chem. ㅇ, 591 (1957).

71. Sturges, U., Kernenergie, 1, 553 (1958).

72. Smythe, L. E. and Gatehouse, B. M., Anal. Chem. 27, 901 (1955).

73. Orndorff, W. R. and Nichols, M. L., J. Am. Chem. Soc. 45, 1439 (1923).

74. Garrido, J., Anales Fis. Quim. 43, 1195 (1947). 
75. Taurins, A., Z. Anal. Chem. 101, 357 (1935).

76. Majundar, A., and De, A..K., J. Indian Chem. Soc. 30, 123 (1953).

77. Gillis, J., Hoste, J., and Pijck, J., Microchim. Acta. 244 (1953).

78. Ghosh, S. P. and Ghose, H. M., J. Indian Chem. Soc. 33, 899 (1956).

79. Young, R. S., Cobalt - I.ts Chemistry, Metallurgy, and Uses, p. 377-380, Reinhold, New York, 1960.

80. Wilkins, D. H. and Hibbs, D. E., Anal. Chim. Acta 16, 449 (1957).

81. Wagenmann, K., Metall. u. Erg. 18, 447 (1921).

82. Lunde11, G. E. F. and Hoffman, J. I., Ind. Eng. Chem. 13, 541 (1921).

83. Brophy, D. H., Ind. Eng. Chem., Anal. Ed. 3, 363 (1931).

84. Scott, W. W. and Furman, N. H., Standard Methods of Chemical Analysis, Vol. 1, 315, The Technical Press, London, 1954.

85. Lingane, J. J. and Page, J. A., Anal. Chim. Acta 13, 281 (1955).

86. Torrance, S., Analyst 64, 109 (1939).

87. Salyer, D. and Sweet, T. R., Anal. Chem. 28, 61 (1956).

88. Salyer, D. and Sweet, T. R., Anal. Chem. 29, 2 (1957).

89. Salyer, D. and Sweet, T. R., Anal. Chem. 30, 1632 (1958).

90. Schleicher, A., Z. Erzbergban u. Metallhuttenw. 2, 210 (1949).

91. Tutundzic, P. S. and Stojkovic, D., Anal. Chim. Acta, 11, 580 (1955).

92. Morrison, G. H. and Freiser, H., Solvent Extraction in Analytical Chemistry, John Wiley and Sons, New York, 1957.

93. Kitahara, S., Bull. Inst. Phys. Chem. Research (Tokyo) 25, 165 (1949).

94. Bock, R. and Herrmann M., Z. anorg. u. allgem. Chem. 284, 288 (1956).

95. Garwin, L. and Hixson, A. M., Ind. Eng. Chem. 41, 2303 (1949).

96. Bock, R., Kusche, H., and Bock. E., Z. anal. Chem. 138, 167 (1953).

97. Demaro, H. R. and Occleshaw, V. J., Anal. Chim. Acta 13, 329 (1955).

98. Kitahara S., Bull. Inst. Phys. Chem. Research (Tokyo) 24, 454 (1948).

99. Bock, R., Z. anal. Chem. 133, 110 (1951).

100. Hall, A. J. and Young, R. S., Analyst 71, 1479 (1949).

101. Moeller, T. and Zogg, R. E., Anal. Chem. 22, 612 (1950).

102. West, P. W., Lyon F. C., and Carlton, J. K., Anal. Chlm. Acta 6, 400 (1952).

103. Mahlman, H. A., Leddicotte, G. W., and Moore, F. L., Anal. Chem. 26, 1939 (1954).

104. Brown, K. B., Coleman, C. F., Crouse, D. J., Denis, J. O., and Moore, J. G., USARC Report ORNL-1734. 
105. Moore, J. G., Brown, K. B., and Coleman, C. F., USAEC Report, ORNL-1922.

106. Dwyer, F. P. and Gibson, N. A., Analyst 76, 548 (1951).

107. Ellis, K. W. and Gibson, N. A., Ansl. Chim. Acta 9, 369 (1953).

108. Boyless, N. S. and Pickering, R. W., Ind. Eng. Chem., Anal. Ed. 18, 446 (1946).

109. Ziegler, M., Z. anal. Cnem. 171, 111 (1959).

110. Brown, W. B. and Stienback, J. F., Anal. Chem. 31, 1805 (1959).

111. Potratz, H. A., "A Rapid Method for the Determination of Cobalt in Uranium," in USAEC Report CC-464.

112. Miller, R. R. and Brandt, W. W., Anal. Chem. 26, 1968 (1954).

113. Tabushi, M., Bull. Inst. Chem. Research, Kyoto Univ., 37, 252 (1959).

114. Morrison, G. H. and Freiser, H., op. cit., p. 158-159.

115. Morrison, G. H. and Freiser, H., op. cit., p. 202.

116. Moeller, T., Ind. Eng. Chem., Anal. Ed. 15, 271, 346 (1943).

117. Duffield, W. D., Analyst 84, 455 (1959).

118. Westwood, W. and Mayen, A., Analyst 73, 275 (1948).

119. Silverman, L., Moudy, L., and Hawley, D. W., Anal. Chem. 25, 1369 (1953).

120. Morrison, G. H. and Freiser, H., op. cit., p. 163-66.

121. Moeller, T., Ind. Eng. Chem., Anal. Ed. 15, 346 (1943).

122. Goldbery, D. E. and Fernelius, W. C., USAEC Report NYO-7946 (1958).

123. Lane, T. J. and Quinlam, K. P., J. Am. Chem. Soc. 82, 2997 (1960).

124. Feng, P. K. and Quintus, F., J. Am. Chem. Soc. 82, 2115 (1960).

125. Sandell, E. B. and Perlich, R. W., Ind. Eng. Chem., Anal. Ed. II, 309 (1939).

126. O1, N., J. Chem. Soc. Japan, Pure Chem. Sect. 75, 1069 (1954).

127. Butts, P. G., Gahler, A. R., and Mellon, M. G., Metal Fimshy 49, 50 (1951).

128. Gahler, A. R., Mitchell, A. M., and Mellon, M. G., Anal. Chem. 23, 500 (1951).

129. Taylor, C. G., Analyst 11 , 369 (1956).

130. Vanossi, R., Anales. Soc. Cient Argentina 131, 226 (1941).

131. Waldbauer, L. and Ward, N. M., Ind. Eng. Chem., Anal. Ed. 14, 727 (1942).

132. Saltzman, B. E., Anal. Chem. 27, 284 (1955).

133. Ronney, R. C., Metallurgia 58, 205 (1958). 
134. Clarch, L. J., Anal. Chem. 30, 1153 (1958).

135. Krohnke, F., Ber. Deut. Chem., Ges. 60, 527 (1927).

136. Cheng, K. L., Anal. Chem. 26, 1895 (1954).

137. Auger, V., LaFontaine, V., and Caspar, C., Compt. Rend. 180, 376 (1925).

138. Shome, S. C., Analyst 75, 27 (1950).

139. Ryan, D. E. and Lutwick, G. E., Can. J. Chem. 31, 9 (1953).

140. Sagani, N. C. and Battachorya, S. C., Anal. Chem. 28, 81, 1616 (1956).

141. Cheng, K. I. and Broy, R. H., Anal. Chem. 27, 782 (1955).

142. Sandell, E. B., Colorimetric Determination of Traces of Metals, and Ed., Interscience, New York, 1950.

143. Sandell, E. B., op. cit.

144. Marston, H. R,, and Dewey, D. W., Anshatu J. Exptl. Biol. Med. Sc1. 18, $343(1940)$.

145. Lacoste, R. J., Earing, M. H., and Weberley, S. E., Anal. Chem. 23, 871 (1953).

146. Compin, L., Ann. Chem. Anal. et Chem. Appl. 2, 218 (1920).

147. Kutzelew, A., Z. anorg. Chem. 256, 46 (1948).

148. Welcher, F. J., Organic Analytical Reagents, Vol. 4, Van Nostrand, Princeton, 1948.

149. Beck, G., Mikrochemie ver. Michrochem Geta 33, 188 (1947).

150. Ayres, G. H. and Tuffly, B. L., Anal. Chem. 24, 949 (1952).

151. Sudo, E., J. Chem. Soc. Japan, Pure Chem. Sect., 75, 1291 (1954).

152. Sacconi, L., Discuss. Faraday Soc. I, 173 (1949).

153. Zechmeister, L., Progress in Chromatography, 1938-1947, Chapmen and Hall, London, 1950.

154. Smith, O. C., Inorganic Chromatography, Van Nostrand, New York, 1953.

155. Pollard, and McOmie, J. F. W., Chromatographic Methods of Inorganic Analys is, Butterworth, London, 1953.

156. Schwab, G. M. and Jockers, K., Naturwissenschaft 25, 44 (1937).

157. Saccont, L., Gazz. Chim. 1tal. 78, 583 (1948).

158. Sacconi, L., Gazz. Chim. 1tal. 79, 141 (1949).

159. Saccont, L., 1bid., p. 152.

160. Sacconi, L., Nature 164, 70 (1949).

161. Venturello, G. and Agliardi, N., Chemical Abstracts 36, $5439 \mathrm{~b}$ (2942).

162. Tanaka, M. and Shibata, M., J. Chem. Soc. Japan, Pure Chem. Sect. 71, 254, 312 (1950). 
163. Tanaka, M. and Shibata, M., J. Chem. Soc. Japan, Pure Chem. Sect. 72, 221 (1951).

164. Lister, B. A. J., Discuss. Faraday Soc. 7, 237 (1949).

165. Erametsa, 0., Chemical Abstracts 40, 4620-8 (1946).

166. Bach, R. O., Industria y quimica 12, 283 (1950).

167. Tanaka, M., Ashjzawa T., and Shibata, M., Chemical Abstracts $4 \underline{3}$, $8945 \mathrm{~h}$ (1949).

168. Tanaka, M. and Shibata, M., J. Chem. Soc. Japan, Pure Chem. Sect. 72, 221 (1951).

169. Paulais, R., Chemical Abstracts 41, 35000d (1947).

170. Berkhout, H. W. and Jongen, G. H., Chemical Abstracts 47, 12107d (1953).

171. King, R. P., Bolin, D. W., Dinusson, W. E., and Buchanan, M. I., Chemical Abstracts 48 , 2946h (1954).

172. Dean, J. A., Anal. Chem. 23, 1096 (1951).

173. Fricke, R. and Schmäh, H., Z. anorg. Chem. 255, 253 (1948).

174. Flood, H., Discuss. Faraday Soc. 7, 190 (1949).

175. Zolotovia, V. L., Chemical Abstracts 48, 12508b (1954).

176. Vanyarkho, I. G. and Garanina, V. A., Chemical Abstracts 47, 439h (1953).

177. Gapon, E. N. and Chernikova, T. N., Chemical Abstracts 43, 3549h (1949).

178. Milone, M. and Cetini, G., Atti, accad. sci. Torino 90,1 (1955/56).

179. Sen, B. N., Australian J. Science 15, 133 (1952/53).

180. Sen, B. N., Z. anorg. u. allgem. Chem. 273, 183 (1953).

181. Gapon, T. B. and Gapon, E. N., Chemical Abstracts 42, 6603e (1948).

182. Smith, D. M. and Hays, J. R., Anal. Chem. 31, 898 (1959).

183. Erlenmeyer, H. and Dahn, H., Helv. Chim. Acta 22, 1369 (1939).

184. Roblnson, G., Metallurgia 37, 45, 107 (1947).

185. Robinson, G., Discuss. Faraday Soc. I, 195 (1949).

186. Shemyakin, F. M. and Mitselovsk1, E. A., Chemical Abstracts $4 \underline{3}$, $8973 b$ (1949).

187. Burriel-Marti F. and Pino-Perez, F., Anal. Chim. Acta 3, 468, (1949).

188. Labruto, G. and d'Alcontres, G. A., Ann. Chem. Appli. 38, 320 (1948).

189. Colmon, C. and Kressman, T. R. E., Editors, Ion Exchange in Organic and Biochemistry, Interscience Publishers, New York, 1957.

190. DiGiacomo, A. and Respoli, G., Bull. Lab. Chim. prov. (Bologna) I, $13(1950)$.

191. Milone, M. and Cetini, G., Chemical Abstracts 48, 5720-g (1954). 
192. Milone, M. and Cetini, G., Chenica e Industria (Milano) 35, 346 (1953).

193. Jain, B. D. and Singhal, S. P., J. Chromat. 2, 324 (1959).

194. Kennedy, J. and Davis, R. V., J. Inorg. and Nuclear Chem. 12, 193-8 (1959).

195. Kraus, K. A. and Moore, G. E., J. Am. Chem. Soc. 75, 1460 (1953).

196. Kraus, K. A. and Nelson, F., J. Am. Chem. Soc. 76, 984 (1954).

197. Kraus, K. A., Nelson, F., Clough, F. B., and Carlston, R. C., J. Am. Chem. Soc. 77, 1391 (1955).

198. Kraus, K. A., Nelson, F., and Smith, G. W., J. Phys. Chem. 58, 11 (1954).

199. Moore, G. E. and Kraus, K. A., J. Am. Chem. Soc. 72, 5792 (1950).

200. Atteberry, R. W., Larson, Q. V., and Boyd, G. E., Abstract Am. Chem. Soc., 118th Meeting 8G (Chicago, September, 1950).

201. Blasius, E. and Newger, M., Naturwissenschaften 39, 257 (1952).

202. Hicks, H. G., Gilbert, R. S., Stevenson, P. C. and Hutchin, W. H., "The Qualitative Anionic Behavior of a Number of Metals With an Ion Exchange Resin, Dowex 2," USAEC Report, LRL-65 (1953).

203. Herber, R. H. and Irvine, J. W., J. Am. Chem. Soc. 76, 987 (1954).

204. Helwig, H. L., Ashikawa, J. K., Clokie, H., and Smith, E. R., "The Separation of Iron and Cobalt on Synthetic Resin, "USAEC Report, UCRL-2296 (1954).

205. Boni, A. L., Anal. Chem. 32, 599 (1960).

206. Samsahl, K., Acta Chem. Scand. 12, No. 6, 1292-1296 (1958).

207. Nelson, F., and Kraus, K. A., J. Am. Chem. Soc. 76, 5916 (1954).

208. Wilkins, D. H. and Hibbs, L. E., Anal. Chim. Acta 20, 427 (1959).

209. Lewis, L. L. and Straub, W. A., Anal. Chem. 32, 96 (1960).

210. Wilkins, D. W., Anal. Chim. Acta 20, 271 (1950).

211. Wilkins, D. H. and Hibbs, L. F., Anal. Chim. Acta 18, (1957).

212. Zeigler, M. and Rittner, W., Z. anal. Chem. 165, 197-200 (1959).

213. Hall, N. F. and Johns, D. H., J. Am. Chem. Soc. 75, 5787 (1953).

214. King, E. L. and Walters, R. R., J. Am. Chem. Soc. 74, 4471 (1952).

215. Lisha, K. and Klin, L., Collection Czechoslov. Chem. Comnuns. 23, 968-70, 970-2 (1958).

216. Fritz, J. A. and Karraher, S. K., Anal. Chim. 32, 957 (1960).

217. Strelow, F. W. E., Anal. Chem. 32, 363-5 (1960).

218. Pennington, L. D. and Williams, M. B., Ind. and Eng. Chem. 51, 759-62 (1959).

219. Millicevic, B., Chemical Abstracts 46, 43198 (1952). 
220. Martin, E. C., Anal. Chim. Acta 2, 511 (1951).

221. Anderson, J. R. A. and Whittey, A., Anel. Chim. Acta 6, 517 (1952).

222. Pickering, W. F., Anal. Chim. Acta 8 , 344 (1953).

223. Hartkamp, H. and Specker, H., Naturwissenschaften 42, 534 (1955).

224. Reeves, W. A. and Crumpler, T. B., Anal. Chem. 23, 1576 (1951).

225. Lederer, M., Anal. Chim. Acta 1, 458 (1952).

226. Szarvas, P., Balough, T., and Toth, B., Magyar Kem. Folyoirat 62, 68 (1956).

227. Lederer, E. and Lederer, M., Chromatography, Elsevier, Amsterdam (1957).

228. Elbeih, I. I., McOmie, J. F. W., and Pollard, F. H., Discuss. Faraday Soc. I, 183 (1949).

229. Weiss, A. and Follab, S., Helv. Chim. Acta 37, 1253 (1954).

230. Na1to, T. and Takahashi, N., Japan Analyșt $\underline{3}$, 125 (1954).

231. Miller, H. and Kraemer, D. M., Anal. Chem. 24, 1371 (1952).

232. Michal, J., Coll. Cfech. Chem. Comons. 211, 276 (1956).

233. Lederer, E. and Lederer M., op. cit., p. 483.

234. Pollard, F. H., Mcomie, J. F. W., and Elbeih, I. I. M., J. Chem. Soc. p. 1951466.

235. Lederer, M., Anal. Chem. Acta. 5, 185 (1951).

236. DeCaralho, R. G., Paper, Inter. Congress of Analytical Chemistry, Lisbon (1956).

237. Walker, W. R. and Lederer, M., Anal. Chim. Acta 5, 191 (1951).

238. Carleson, G., Acta Chem. Scand. 8, 1673 (1954).

239. Kertes, S. and Lederer, M., Anal. Chim. Acta 15, 543 (1956).

240. Lederer, M., Anal. Chem. Acta. 12, 146 (1955).

241. Lederer, E. and Lederer, M., op. cit., p. 497.

242. Shibata, M. and Uemura, T., J. Chem. Soc. Japan, Pure Chem. Sect. 72, 541 (1951).

243. Airan, J, W., Chemical Abstracts 47, 2625h (1953).

244. Airan, J. W. and Barnabas, J., Chemical Abstracts, 47, 8580b (1953).

245. Tewar1, S. N., Kollo1d - Z. 138, 178 (1954).

246. Burstall, F. H., Davis, G. R., Linstead, R. P., and Wells, R. A., J. Chem. Soc., 1950, p. 516.

247. Frierson, W. J. and Ammons, M. J., J. Chem. Educ. 27, 37 (1950).

248. Harasawa, S. and Takasu, K., J. Chem. Soc. Japan, Pure Chem. Sect. 76, 173 (1955). 
249. Von Hahn, H., Sorkin, E., and Erlenmeyer, H., Experientia 7, 358 (1951).

250. Lacourt, A., Sommereyns, G., DeGeyndt, E., Baruh, J., and Giliard, J., Mikrochem. ver. Mickrochem. Acta 34, 215 (1949).

251. Lacourt, A., Gillard, J., and Van der Walle, M., Nature 166, 225 (1950).

252. Michalowicz, A. and Lederer, M., J. Phys. Radium 13, 669 (1952).

253. Lederer, E. and Lederer, M., op. cit., p. 530.

254. Burstall, F. H., Davies, G. R., and Wells, R. A., Discuss. Faraday Soc. I, 179 (1.949).

255. Anderson, J. R. A. and Lederer, M., Anal. Chim. Acta 4, 513 (1950).

256. Laskowski, D. E. and McCrone, W. C., Anal. Chem. 23, 15.79 (1951).

257. Pollard, F. H., Banster, A. J., Geary, W. J., and Michless, G., J. Chromato. 2, 372-79 (1959).

258. Yamamato, Y., Nahahara, A., and Tschuchid, R., J. Chrom. Soc. Japan $75,232(1954)$.

259. Lederer, F., Anal. Chim. Acta 13, 350 (1955).

260. Singh, E. J. and Dey, A. K., Anal. Chim. 159, 290 (1958).

261. Weidmann, G. R., Can. J. Chem. 37, 830 (1959).

262. Singh, E. J. and Dey, A. K., J. of Chromato. 3, 146-49 (1960).

263. Frierson, W. J., Rearich, D. A., and Yoe, J. H., Anal. Chim. 30, 468 (1958).

264. Berg, E. W. and Strasser, J. F., Anal. Chim. 27, 127 (1955).

265. Majumdar, A. K. and Singh, B. R., Anal. Chim. Acta 19, 520 (1958).

266. Hillebrand, w. F., et al., op. cit., p. 417.

267. Gibbons, D., Int. J. App. Rad. and Isotopes 4, 45 (1958).

268. Gorsuch, T. T., Analyst 84, 135-173 (1959).

269. Pieters, H. A. J. and Creyghton, J. W., Safety in tne Chemical Laboratory, Academic Press, New York (1957).

270. Leddicotte, G. W., Reynolds, S. A., and Corbin, L. T., Safety, Method No. 50150, ORNL Master Analytical Manual, TID-7015, Section 5 .

271. Reymolds, S. A., Record of Chemfcal Progress 16, 99 (1955).

272. Price, W. J., Nuclear Radiation Detection, McGraw-Hill, New York (1958).

273. Siegbahn, K., Beta- and Gamma-Ray Spectroscopy, Pergamon Press, New York $(1950)$.

274. Crouthamel, C., Applied Gamma-Ray Spectrometry, Pergamon Press, New York (1960).

275. Boyd, G. E., Anal. Chem. 21, 335 (1949). 
276. Leddicotte, G. W., Pure and Applied Chemistry $\underline{1}$, 61-80 (1960).

277. Schonken, P., "Neutron Activation Analysis," NP-6971 (1958).

278. Bate, L. C. and Leddicotte, G. W., "The Quantitative Analysis of Complex Radionuclide Mixtures by Gamma-Ray Spectrometry," ORNL-2917 (in press).

279. Salmon, L., "Gamma Spectroscopy Applied to Radioactivation Analysis," Atomic Energy Research Establishment Report, Harwell, England, AERE C/R 2377(3), (1958).

280. Guss, D. E. and Leddicotte, G. W., "The Use of Inconel as a High Temperature, Corrosion Resistant, Thermal Neutron Flux Monitor, USAEC Report No. ORNL CF-59-3-53 (March, 1959).

281. Dragoum1s, P., Weir, J. R. and Ieddicotte, G. W., "Fast-Flux Measurements in the ORR Core," USAEC Report No. ORNL-3028 (1961).

282. Enery, J., Analytical Chemistry Division, Oak Ridge National Laboratory, private communication.

283. Westermark, T. and Fineman, I., Proc. 2nà U. N. Conf. On Peaceful Uses of Atomic Energy, 1958, 28, 506 (1959).

284. Kaiser, D. G. and Meinke, W. W., Talanta 3, 255 (1960).

285. Mullins, W. T., Bate, L. C., Emery, J. F. and Leddicotte, G. W., unpublished data.

286. Leddicotte, G. W., "Cobalt, Neutron Activation Analysis (IsotopicCarrier Precipitation) Method," Method No. 5-11220, ORNL Master Analytical Manual (1960). Supplement 3 of TID-7015 (in preparation).

287. Eristavi, D. I., Brouchek, F. T. and Tsivtsivadze, T. A., Zhur. Anal. Khimii 2, 631-3 (1959).

288. Meinke, W. W., "Chemical Frocedures Used in the Bombardment at Berkiey," USAEC Report No. AECD-2738 (1949).

289. Kleinberg, J., "Collected Radiochemical Procedures," USAEC Report No. IA-1721, 2nd Ed., March, 1960.

290. Brooksbank, W. A., Leddicotte, G. W. and Mahlman, H. A., J. Phys. Chem. 57, 815 (1953).

291. Hall, T. A., Nucleonics 12 No. 3, 34 (1954).

292. Toblas, C. A., Wolfe, R., Dunn, R. and Rosenfield, I., Unio. Internationalis Contra Cancrum, Acta 7,874 (1952).

293. Benson, A. A., Proc. Second United Nations Conf. on Peaceful Uses of Atomic Energy, Geneva 1958, 24289 (1959).

294. Dale, B. McS., Dissertation Abstracts 20, 472 (1959).

295. Koch, H. J., Smith, E. R., Shimp, N. F. and Connor, J., Cancer 9, 499 (1956).

296. Leddicotte, G. W., Mullins, W. T., Bate, L. C. Emery, J. F., Druschel, R. E. and Brooksbank, W. A., Proc. Second United Nations Conf. on Peaceful Uses of Atomic Energy, Geneva 1958, 15, 927 (1959).

297. Leddicotte, G. W., Cobalt, Neutron Activation Analysis (IsotopicCarrier Precipitation) Method, Method No. 5-11220, ORNL Master Analytical Manual (1960). Supplement 3 of TID-7015 (in preparation). 
298. Leddicotte, G. W., Cobalt, Neutron Activation Analysis (Ion-Exchange) Method, Method No. 5-11222, ORNL Master Analytical Manual (1961). Supplement 3 of TID-7015 (in preparation).

299. Smalks', A. A., Proc. Intern. Conf. Peaceful Uses of Atomic Energy, Geneva, 1955, 2, 273 (1956).

300. Albert, P., Caron, M. and Chandron, G., Compt. rend. 236, 1030 (1953).

301. Riezler, W., Z. Naturforech 4a, 545 (1949).

302. Talbot, J., Albert, P., Caron, M. and Chaudron, G., Rev. Met. $\underline{50}$, 817 (1953).

303. Debiesse, J., Challansonnet, J. and Nyret, G., Compt. rend, 232, 602 (1951).

304. Cornand, P., and Gillis, J., Ind. Chim. belge 20, Xpeclal No. 269 (1959).

305. Monnier, D. Haerd1, W. and Vogel, J., Helv. Chim. Acta 43, 675 (1960).

306. Goldberg, E., Uchiyama, A. and Brown, H., Geochim. et Cosmochim. Acta 2, 1 (1951).

307. Smales, A. A., Mapper, D. and wood, A. J., Analyst 82, 75 (1957).

308. Smales, A. A., Mapper, D. and Wood, A. J., Geochim. et Cosmochim. Acta 13, 123 (1958).

309. Smales, A. A., Geochim. et Cosmochim. Acta $\underline{8}, 300$ (1955).

310. Wager, L. R., Vincent, E. A. and Smales, A. A., Economic Geology 52, 855 (1957).

311. Smales, A. A. and Wiseman, J. D. H., Nature 175, 464 (1955). 


\title{
NUCLEAR SCIENCE SERIES: MONOGRAPHS ON RADIOCHEMISTRY, RADIOCHEMICAL TECHNIQUES, AND NUCLEAR MEDICINE
}

\author{
Avallable from the Natıonal Technical Information Service, \\ U S Department of Commerce, Sprıngfield, Vırgını 22161
}

\section{ELEMENTS}

Aluminum and Gallum, NAS-NS-3032 [1961]. $\$ 925$

Americium and Curıum, NAS-NS-3006 [1960], $\$ 975$

Antımony, NAS-NS-3033 [1961], $\$ 950$

Arsenic, NAS-NS-3002 (Rev) [1965], $\$ 900$

Astatine, NAS-NS-3012 [1960], \$8 75

Barium, Calcium, and Strontuum. NAS-NS3010 [1960], \$11 00

Berylluum, NAS-NS-3013 [1960], $\$ 950$

Bismuth, NAS-NS-3061 [1977], \$1175

Cadmium, NAS-NS-3001 [1960], $\$ 950$

Carbon, Nitrogen, and Oxygen, NAS-NS3019 [1960], \$850

CesIum, NAS-NS-3035 [1961], \$975

Chromium, NAS-NS-3007 (Rev) [1963], \$9 50

Cobalt, NAS-NS-3041 [1961], \$10 25

Copper, NAS-NS-3027 [1961], \$9 50

Fluorine, Chlorine, Bromine, and lodine, NAS-NS-3005 [1960], \$9 25

Francium, NAS-NS-3003 [1960], $\$ 900$

Germanuum, NAS-NS-3043 [1961], \$9 25

Gold, NAS-NS-3036 [1961], $\$ 900$

Indium, NAS-NS-3014 [1960], $\$ 950$

lodine, NAS-NS-3062 [1977], \$11 00

Iridum, NAS-NS-3045 [1961], \$875

Iron, NAS-NS-3017 [1960], \$9 25

Lead, NAS-NS-3040 [1961], $\$ 1200$

Magnesuum, NAS-NS-3024 [1961], \$875

Manganese, NAS-NS-3018 (Rev) [ 1971], $\$ 975$

Mercury, NAS-NS-3026 (Rev) [1970], $\$ 1300$

Molybdenum, NAS-NS-3009 [1960], $\$ 900$

Neptunium, NAS-NS-3060 [1974], \$1375

Nickel, NAS-NS-3051 [1961], \$1125

Niobium and Tantalum, NAS-NS-3039 [1961], $\$ 950$

Osmum, NAS-NS-3046 [1961], \$850

Palladum, NAS-NS-3052 [1961], $\$ 1100$

Phosphorus, NAS-NS-3056 [1962], $\$ 900$

Platınum, NAS-NS-3044 [1961], $\$ 875$

Plutonum, NAS-NS-3058 [1965], \$12 75

Polonium, NAS-NS-3037 [1961], \$975

Potassium, NAS-NS-3048 [1961]. \$9 25

Protactınium, NAS-NS-3016 [1959], $\$ 1000$

Radium, NAS-NS-3057 [1964], \$13 25

Rare Earths-Scandium, Yttrium, and Actunum NAS-NS-3020 [1961], $\$ 1500$

Rare Gases, NAS-NS-3025 [1960], \$9 50

Recent Radiochemical Separation Procedures for As, At, Be, Mg, $\mathrm{N} t, \mathrm{Ru}$, and Se, NAS-NS3059 [1974], \$10 25

Rhenum, NAS-NS-3028 [1961], \$9 25

Rhodium, NAS-NS-3008 (Rev) [1965], $\$ 1000$

Rubıdium, NAS-NS-3053 [1962], \$10 25

Ruthenium, NAS-NS-3029 [1961] $\$ 1000$
Selenium, NAS-NS-3030 (Rev) [1965], \$9 50

Silicon NAS-NS-3049 (Rev) [1968], \$10 00

Silver, NAS-NS-3047 [1961], \$950

Sodium, NAS-NS-3055 [1962], \$9 25

Sulfur, NAS-NS-3054 [1961], \$950

Technetium, NAS-NS-3021 [1960], $\$ 950$

Tellurium, NAS-NS-3038 [1960], \$9 25

Thorum, NAS-NS-3004 [1960], \$975

Tin, NAS-NS-3023 [1960], $\$ 975$

Titanium, NAS-NS-3034 (Rev) [1971], $\$ 1025$

Transcurium Elements, NAS-NS-3031 [1960], $\$ 900$

Tungsten, NAS-NS-3042 [1961], \$925

Uranium, NAS-NS-3050 [1961], $\$ 1700$

Vanadium, NAS-NS-3022 [1960], $\$ 1000$

Zinc, NAS-NS-3015 [1960], \$9 50

Zirconium and Hafnium, NAS-NS-3011 [1960], $\$ 950$

\section{TECHNIQUES}

Absolute Measurement of Alpha Emission and Spontaneous Fission, NAS-NS-3112 [1968], \$975

Activation Analysis with Charged Particles, NAS-NS-3110 [1966], \$925

Application of Distillation Techniques to Radiochemical Separatıons, NAS-NS-3108 [1962], \$9 00

Applications of Computers to Nuclear and Radiochemistry, NAS-NS-3107 [1962], \$16 00

Cation-Exchange Techniques in Radiochemistry, NAS-NS-3113 [1971], $\$ 1300$

Chemical Yield Determinations in Radıochemistry, NAS-NS-3111 [1967], $\$ 1050$

Detection and Measurement of Nuclear Radiation, NAS-NS-3105 [1961], $\$ 1150$

Liquid-Liquid Extraction with HighMolecular-Weight Amınes, NAS-NS-3101 [1960], \$1025

Low-Level Radiochemical Separations. NAS-NS-3103 [1961], $\$ 900$

Neutron Activation Techniques for the Measurement of Trace Metals in Environmental Samples, NAS-NS-3114 [1974], \$10 25

Paper Chromatographic and Electromigration Techniques in Radıochemistry, NAS-NS3106 [1962], \$9 25

Processing of Countıng Data, NAS-NS-3109 [1965], \$1225

Rapid Radiochemical Separations, NAS-NS3104 [1961], \$1125

Separations by Solvent Extraction with Tri-n-octylphosphine Oxide, NAS-NS-3102 [1961], \$9 50

Users Guides for Radioactivity Standards, NAS-NS-3115 [1974], \$10 25 